Der Medizinischen Fakultät der Georg-August-Universität Göttingen eingereicht von Prof. Dr. rer. nat. H. Jarry, V1 Tierschutzbeauftragter

\title{
Vergleichende In-Vivo- und In-Vitro-Untersuchungen zur Bestimmung der CYP1A1-Aktivitätsveränderung durch hormonell aktive Stoffe
}

\author{
INAUGURAL-DISSERTATION \\ zur Erlangung des Doktorgrades \\ der Medizinischen Fakultät der \\ Georg-August-Universität zu Göttingen
}

vorgelegt von

Karen Veelken

aus

Hamburg

Göttingen 2014 
Die Arbeit ist im Zeitraum von 09/2005 bis 05/2007 an der Abteilung für Klinische und Experimentelle Endokrinologie in Göttingen entstanden.

Dekan: $\quad$ Prof. Dr. rer. nat. H. K. Kroemer

I. Berichterstatter: Prof. Dr. rer. nat. H. Jarry

II. Berichterstatter: PD Dr. rer. nat. M. Tzvetkov

III. Berichterstatter: Prof. Dr. M. Oppermann

Tag der mündlichen Prüfung: 02.06.2015 
Abkürzungsverzeichnis

\section{Abkürzungsverzeichnis}

In dieser Arbeit wurden die internationalen SI-Einheiten und davon abgeleitete Einheiten mit SI-Präfixen verwendet.

3MC

4MBC

A

Abb.

AF-2

AhR

ANOVA

AP-1

ARNT

bHLH/PAS

bzw.

C

ca.

cAMP

cDNA

CT

CYP

DDT

DES

dest

d.h.

DMSO

DMEM
3-Methylcholanthren

4-Methylbenzylidene Camphor

Adenosin

Abbildung

activation function-2 domain

Arylhydrocarbon-Rezeptor

analysis of variance

activator protein 1

aryl hydrocarbon receptor nuclear translocator

basic Helix-Loop-Helix/Per-Arnt-Sim

beziehungsweise

Cytidin

circa

Zyklisches Adenosinmonophosphat

komplementäre DNA

threshold cycle (Fluoreszenzschwellenwert)

Cytochrom-P450-Enzym

Dichlordiphenyltrichlorethan

Diethylstilbestrol

destilliert

das heißt

Dimethylsulfoxid

dulbecco's modified eagle's medium 
Abkürzungsverzeichnis

\begin{tabular}{|c|c|}
\hline DNA & Desoxyribonukleinsäure \\
\hline dNTP & desoxy-Nukleotidtriphosphat \\
\hline DRE & dioxin responsive element \\
\hline E2 & $17 \beta$-Estradiol \\
\hline E2V & $17 \beta$-Estradiolvalerat \\
\hline EAC & endokrin aktive Chemikalie \\
\hline ED & endokriner Disruptor \\
\hline EDTA & Ethylendiamintetraacetat \\
\hline ELISA & enzyme-linked immunosorbent assay \\
\hline EPA & US-Umweltschutzbehörde \\
\hline ER & Estrogen-Rezeptor \\
\hline ERE & estrogen response element \\
\hline EROD & Ethoxyresorufin-O-deethylase \\
\hline $\mathrm{EtOH}$ & Ethanol \\
\hline FAM & 6-Carboxy-fluorescein \\
\hline FKS & fetales Kälberserum \\
\hline Fos/Jun & Heterodimerkomplex, bilden zusammen AP-1 \\
\hline G & Guanosin \\
\hline HSP90 & chaperon Heat shock-Protein 90 \\
\hline ICI 182,780; ICI & Estrogen-Rezeptor-Antagonist \\
\hline Kg & Körpergewicht \\
\hline $\mathrm{mM}$ & millimolar \\
\hline$\mu \mathrm{M}$ & mikromolar \\
\hline mRNA & messenger-RNA \\
\hline NCBI & National Center for Biotechnology Information \\
\hline $\mathrm{NADP}^{+} / \mathrm{NADPH}$ & Nicotinsäureamid-Adenin-Dinukleotid-Phosphat \\
\hline
\end{tabular}


Abkürzungsverzeichnis

$\mathrm{N}-\mathrm{CoR}$

NLS

$\mathrm{nM}$

OD

PAK

PBB

PBS

PCB

PCDDs/PCDFs

PCR

Pen/Strep

$\mathrm{pH}$

PHAK

PKM

$\mathrm{pM}$

RNA

RNase

RNasin

RT

RT-PCR

RTD-PCR

SEM

SERM

SHR

SMRT

sog. nuclear receptor co-repressor

$\mathrm{N}$-terminal nuclear localisation signal

nanomolar

optische Dichte

polyzyklische aromatische Kohlenwasserstoffe

polybromierte Biphenyle

Phosphat-gepufferte Saline

polychlorierte Biphenyle

polychlorierte Dibenzo-p-dioxine/ Dibenzofurane

Polymerase-Kettenreaktion

Penicillin/Streptomycin

negativer dekadischer Logarithmus der Wasserstoffionenkonzentration

polyhalogenierte aromatische Kohlenwasserstoffe

Permanentkultur-Medium

picomolar

Ribonukleinsäure

Ribonuklease

Ribonuklease-Inhibitor

Raumtemperatur, auch reverse Transkription

real-time PCR

real-time detection-PCR

Standardfehler des Mittelwertes

selective estrogen receptor modulator

Steroidhormonrezeptoren

silencing mediator for retinoid or thyroid-hormone receptors

sogenannt 
Abkürzungsverzeichnis

SP-1

specificity protein 1

SRC-1

steroid receptor coactivator-1

$\mathrm{T}$

Thymidin

Tab.

Tabelle

TAMRA

6-Carboxy-tetramethyl-rhodamin

TCDD

2,3,7,8-Tetrachlordibenzodioxin

Tris

Tris(hydroxymethyl)aminomethan

UpM

Umdrehungen pro Minute

UV

ultraviolett

Velc

Velcorin

VS.

versus

XAP2

Hepatitis B Virus-assoziiertes Protein 2

XRE

xenobiotic responsive element

z.B.

zum Beispiel 
Abkürzungsverzeichnis

1 Einleitung

1.1 Endokrin aktive Chemikalien und Endokrine Disruptoren

1.1.1 Historische Entwicklung des Themengebiets

1.1.2 Mögliche Auswirkungen der EDs auf die Gesundheit des Menschen___ 2

1.1.3 Mechanismen der endokrinen Disruption ___ 4

1.2 Estrogen-Rezeptoren und ihre Liganden __ 4

1.2.1 Endogene Estrogene _ 4

1.2.2 Estrogen-Rezeptoren 5

1.2.3 Der UV-Filter 4MBC als Xenoöstrogen __ 6

1.3 Der Arylhydrocarbon-Rezeptor und seine Liganden

1.3.1 Der Arylhydrocarbon-Rezeptor___ 7

1.3.2 Der AhR-Signalweg __ 8

1.3.3 Liganden des AhR 9

1.3.4 TCDD _ـ 10

1.4 Interaktion von ER $\alpha$ und AhR 11

1.4.1 Hypothesenbildung/Entdeckung — 11

1.4.2 Mechanismen der Interaktion

$1.5 \quad$ Ziel der Arbeit und Methodenwahl___ 12

1.5.1 EROD-Assay ___ 13

1.5.2 Auswirkung von Estradiol und 4 MBC auf die In-Vitro-Genexpression__ 13

1.5.3 Auswirkungen von Estradiol und 4MC auf die In-Vivo-Genexpression__ 14

1.5.4 EROD-Assays am Zellhomogenat___ 14

2 Material und Methoden__ 15

2.1 Testsubstanzen

2.2 Chemikalien und Reagenzien

2.3 Verbrauchsmaterialien__ 17

2.4 Lösungen _ 18

2.4.1 Zellkultur 18

2.4.2 Molekularbiologische Arbeiten__ 18

$2.5 \quad$ Zellkultur___ 18

2.5.1 Kultivierung__ 18

2.5.2 EROD-Assay__ 19

2.5.3 Homogenatgewinnung aus H4IIE-Zellen 20

2.5.4 Protein-Bestimmung nach Bradford __ 21

2.5.5 EROD-Assay mit Zellhomogenat _ 21

2.6 Tierversuch _ 22

2.6.1 Versuchstiere und Haltungsbedingungen 23

2.6.2 Subakute Applikation von Testsubstanzen 23

2.6.3 Sektion__ 23

2.6.4 Messparameter__ 24

2.6.5 Serumanalyse durch Radioimmunoassay __ 24

2.7 Molekularbiologische Arbeiten

2.7.1 Arbeiten mit Nukleinsäuren___ 24

2.7.2 RNA-Extraktion 25

3.4.3.1 Aus Zellkultur _ 25

3.4.3.2 Aus Mäuselebergewebe __ 25

2.7.3 Konzentrationsbestimmung der RNA _ 26
26

2.7.4 Reverse Transskription (RT)___ 26 
2.7.5 Real-Time Detection PCR (RTD-PCR)___ 27

3.4.3.1 Methode__ 27

3.4.3.2 Durchführung__ 27

2.8 Statistische Auswertung ___ 29

3 Ergebnisse _ 30

3.1 EROD-Assay mit Zellkultur _ 30

3.1.1 EROD-Assay mit 3MC _ 30

3.1.2 EROD-Assay mit Estradiol __ 31

3.1.3 EROD-Assay mit 4MBC _ 32

3.1.4 EROD-Assay mit Estradiol und ICI __ 34

3.1.5 EROD-Assay mit 4MBC und ICI — 35

3.1.6 EROD-Assay mit E2-ähnlichen Substanzen __ 36

3.1.7 EROD-Assay mit E2-ähnlichen Substanzen und 3MC __ 37

3.2 Genexpressionsdaten der Zellkultur _ 38

3.2.1 Genexpression von CYP1A1___ 38

3.2.2 Genexpression von AhR _ 39

3.2.3 Genexpression ARNT _ 40

3.3 Tierversuchsdaten___ $\mathbf{4 1}$

3.3.1 Tier- und Organgewichte___ 41

3.4.3.1 Tiergewichte — 41

3.4.3.2 Lebergewichte _ 42

3.3.2 Serumanalyse___ 43

3.3.3 Genexpressionsdaten der Leber__ 43

3.4.3.1 Genepression von Cyp1A1_ 44

3.3.4 Genexpression von AhR und ARNT__ 44

3.4.3.1 Genexpression von $\mathrm{ER} \alpha \_46$

3.4 EROD-Assay mit Zellhomogenat ___ 47

3.4.1 Resorufinzeitprodukt___ 47

3.4.2 EROD-Assay mit 3MC_L 48

3.4.3 EROD-Assay mit Estradiol und 4MBC___ 49

3.4.4 EROD-Assay mit E2-verwandten Substanzen__ 50

4 Diskussion__ 51

4.1 Modifikation der induzierten CYP1A1-Aktivität im Zellkultur-EROD-Assay _ 51

4.1.1 Auswirkung von 3MC___ 51

4.1.2 Auswirkung von Estradiol, 4MBC und ICI___ 52

4.1.3 Auswirkung durch E2-ähnliche Substanzen __ 54

4.2 Modifikation der Genexpression in der H4IIE-Zellkultur _ 54

4.2.1 Auswirkung auf die Genexpression von CYP1A1 54

4.2.2 Auswirkung auf die Genexpression von AhR und ARNT__ 55

4.3 Auswirkungen von 3MC, Estradiol und 4MBC im Tierversuch _ 56

4.3.1 Gewicht und Serumparameter ___ 56

4.3.2 Auswirkung auf die hepatische Genexpression___ 57

4.4 Effekte auf die CYP1A1-Aktivität des EROD-Assays im Zellhomogenat___ 58

4.4.1 Einfluss von 3MC _ 58

4.4.2 Einfluss von Estradiol und 4MBC__ 59

4.4.3 Einfluss von estrogenen Stoffen sowie anderen Substanzen __ 60

4.5 Bewertung und Methodenkritik _ 61

5 Zusammenfassung _ 63

6 Literatur 65 
Inhaltsverzeichnis

7 Anhang

78

7.1 Primersequenzen 78 


\section{$1 \quad$ Einleitung}

\subsection{Endokrin aktive Chemikalien und Endokrine Disruptoren}

„Bei den Endokrinen Disruptoren handelt es sich um körperfremde Verbindungen, die in das endokrine System eines gesunden Organismus oder das seiner Nachkommen eingreifen und zu signifikanten Gesundheitsstörungen führen. “ Diese Definition war eines der Ergebnisse der 1996 in Weybridge abgehaltenen Konferenz „The Impact of Endocrine Disrupters on Human Health and Wildlife" unter der Leitung der EU-Kommission DG XII, der European Environment Agency und dem European Center for Environmental Health der WHO (Bruhn et al. 1999, s.S. 6). Ein paar Jahre zuvor hatte Theo Colborn 1996 mit ihrem Buch „Our stolen future“ (Colborn et al. 1996) weltweit öffentliches Aufsehen erregt mit einem Thema, welches in der Wissenschaft schon länger diskutiert wurde: Besteht ein Zusammenhang zwischen den Fortpflanzungsstörungen bei Mensch und Tier und der Belastung durch anthropogene Umweltchemikalien?

\subsubsection{Historische Entwicklung des Themengebiets}

Seit dem zweiten Weltkrieg ist die weltweite Verbreitung von synthetischen Chemikalien durch die sogenannte „Grüne Revolution“ sprunghaft angestiegen. Neue Errungenschaften in der Nuklear-, Chemie- und Agrarindustrie, deren Abfallprodukte unkontrolliert in die Umwelt gelangten, wurden bedenkenlos angewendet. Derzeit werden jährlich 75.000 verschiedene Chemikalien in den USA produziert (Markey et al. 2003). Etwa seit Mitte der 80-er Jahre nahmen die Berichte in der Literatur über Hormon- und Reproduktionsprobleme bei wildlebenden Tierpopulationen zu (Daxenberger 2002). Konkrete Zusammenhänge zwischen diesen Beobachtungen und der Verbreitung von Umweltchemikalien konnten erstmals am Beispiel der aquatischen Verseuchung mit Dichlordiphenyldichlorethen - einem Abbauprodukt des Insektizids DDT - hergestellt werden. Diese führte beispielsweise bei jungen männlichen Alligatoren im Apopka-See in Florida zu einer abnormen sexuellen Entwicklung und nachfolgender Zeugungsunfähigkeit (Guillette et al. 1994). Ein Populationsrückgang von fischfressenden Vögeln der Great Lakes in den USA - durch erhöhte Vulnerabilität der Eierschalen - erholte sich nach dem Verbot von DDT (Grier 1982). Der initiale Anstoß zu wissenschaftlichen Studien über „Endokrine Disruptoren“ (EDs) entstand während der Wingspread Conference 1991 unter dem Vorsitz von Colborn 


\section{Einleitung}

(Hotchkiss et al. 2008), welche mit diesem Begriff auch die englischsprachige wissenschaftliche Literatur des Themengebiets prägte (Colborn et al. 1993). Anders als die sonst übliche Bezeichnung der „Endokrin aktiven Chemikalien“ (EACs) impliziert dieser die schädigenden Auswirkungen auf das endokrine System eines Organismus während der Entwicklung und späteren Adoleszenz. Die Definitionen der EDs unterscheiden sich je nach Institution. Während die „Weybridge-Definition“ eine nachweisbar schädigende Wirkung auf einen intakten Organismus voraussetzt, reicht der US-Umweltschutzbehörde (EPA) der Nachweis der Beeinflussung eines oder mehrerer endokriner Systeme, um eine Substanz als endokrin wirksam einzustufen. Ein endokriner Disruptor wird hier definiert als körperfremder Stoff, der Synthese, Sekretion, Transport, Metabolismus, Bindung, Wirkung oder Elimination von natürlichen Hormonen im Körper beeinflusst, welche verantwortlich sind für die Aufrechterhaltung der Homöostase, der Reproduktion und der Regulation von Entwicklungsprozessen und des Verhaltens (Bruhn et al. 1999).

Die Gruppe der Substanzen, die inzwischen als endokrin wirksam anerkannt sind, ist sehr heterogen und umfasst neben synthetischen Chemikalien auch natürliche Substanzen wie Phyto- und Mykoestrogene. Unter den exogenen Substanzen anthropogenen Ursprungs (Xenobiotika) finden sich industrielle Löse- und Schmiermittel und deren Nebenprodukte (z.B. PCBs, PBBs, Dioxine sowie Kunststoffe (Bisphenol A), Weichmacher (Phthalate), Pestizide (z.B. DDT), Fungizide und pharmazeutische Produkte (DES) (Diamanti-Kandarakis et al. 2009). Obwohl die Verwendung vieler dieser Substanzen (z.B. DDT und PCBs) schon seit den 70-er Jahren verboten ist, führen die erhebliche Biopersistenz und die langen Halbwertszeiten dieser Verbindungen zu einer Akkumulation in der Nahrungskette (Markey et al. 2002).

\subsubsection{Mögliche Auswirkungen der EDs auf die Gesundheit des Menschen}

Durch das große wissenschaftliche und öffentliche Interesse an den möglichen Auswirkungen der latenten Exposition gegenüber EDs auf das endokrine System des Menschen existieren über dieses Thema inzwischen zahlreiche Studien, doch für die meisten Substanzen konnte bisher keine sichere Aussage über deren endokrines Potential bzw. das Risiko für den Menschen getroffen werden (Safe 2004; Hotchkiss et al. 2008). Dass die Sorge um die adversen Folgen der den Menschen ubiquitär umgebenden Umweltchemikalien für die Gesundheit durchaus ihre Berechtigung hat, zeigen beispielsweise Beobachtungen erhöhter Krebsraten nach Expositionen gegenüber Chemikalien wie DDT oder synthetischen 


\section{Einleitung}

Estrogenen wie Diethylstilbestrol (DES), welches in den 50-er bis 70-er Jahren zur Prävention von Fehlgeburten sowie zur Empfängnisverhütung verabreicht wurde.

Im Folgenden werden einige der derzeit diskutierten Beeinträchtigungen der menschlichen Gesundheit dargestellt, für welche die Endokrinen Disruptoren mitverantwortlich gemacht werden:

Spermienqualität: Der von Carlsen et al. beobachtete Rückgang der durchschnittlichen Spermienanzahl um bis zu 50\% während der letzten 50 Jahre in den westlichen Industrienationen (Carlsen et al. 1992) führte zu der umstrittenen Hypothese, dass dieser als mögliche Auswirkung der Belastung durch östrogen wirksame Chemikalien angesehen werden kann (Sharpe und Skakkebaek 1993). Die prä- und postnatale Exposition gegenüber PCB-kontaminiertem Reisöl in Taiwan führte zu einer signifikanten Verschlechterung der Spermienqualität bezüglich Morphologie und Motilität (Guo et al. 2000; Hsu et al. 2003).

Hodenkarzinome: Die Hodenkrebsinzidenz hat in den westlichen Industrienationen während der letzten 30 Jahre signifikant zugenommen (Huyghe et al. 2003). Die pränatale Exposition gegenüber DES führte zu einem erhöhten Erkrankungsrisiko (Toppari et al. 1996).

Prostatakarzinom: Epidemiologische Studien zeigen eine signifikant erhöhte Inzidenz von Prostatakarzinomen bei Farmern, die hormonell aktive Pestizide einsetzten (Morrison et al. 1993; Alavanja et al. 2003; Van Maele-Fabry et al. 2006; Meyer et al. 2007).

Brustkrebs: Die altersstandardisierte Brustkrebsinzidenz in Deutschland stieg von 1980 bis 2004 stetig von 69 auf 104 Fälle pro 100.000 Einwohner (Batzler et al. 2008). Es ist bekannt, dass Estrogene grossen Einfluss auf das Erkrankungsrisiko haben (Katalinic et al. 2009). Auch die Exposition gegenüber Organochloriden und DDT zeigte in prospektiven Studien einen positiven Zusammenhang mit der Inzidenz des Mamma-Karzinoms (Hoyer et al. 1998; Cohn et al. 2007).

Teratogenese weiblicher Genitalien: Bei Töchtern der mit DES während der Schwangerschaft behandelten Mütter konnte ein drastischer Anstieg in der Inzidenz des sonst sehr seltenen vaginalen Adenokarzinoms festgestellt werden (Herbst et al. 1971).

Diskutiert werden zudem Assoziationen von endokrin aktiven Substanzen unter anderem mit dem Auftreten von Hypospadie (Baskin et al. 2001), Endometriose (Yang et al. 2000; Rier und Foster 2003), polyzystischem Ovarialsyndrom (Takeuchi et al. 2004), Adipositas und metabolischen Störungen (Grun und Blumberg 2006; Newbold et al. 2007) sowie Auswirkungen auf das neuroendokrine System (Gore 2001), Schilddrüsenfunktion (BruckerDavis 1998), und das Immunsystem (Selgrade 2007). 


\section{Einleitung}

\subsubsection{Mechanismen der endokrinen Disruption}

Folgende Mechanismen kommen als Möglichkeiten für eine Störung des hormonellen Systems durch Endokrine Disruptoren in Betracht:

- Durch die Bindung an die Hormonrezeptoren der Erfolgsorgane können EDs als Agonisten bzw. Antagonisten fungieren und damit hormonelle Wirkungen induzieren bzw. diese hemmen (Gülden et al. 1997).

- Die Rezeptorfunktion und somit die hormonelle Wirkung kann durch Blockade des Rezeptors und dessen Kofaktoren sowie durch Störung der Bindung an das Genom inhibiert werden (Kelce et al. 1995; Swedenborg et al. 2009). Auch die Induktion des Rezeptorabbaus mittels Ubiquitinierung wurde beschrieben (Wormke et al. 2003).

- Die Verfügbarkeit von endogenen Hormonen kann durch Veränderung von Produktion, Sekretion, Transport oder Metabolismus gestört werden (Thierfelder et al. 1995; Gülden et al. 1997).

Für die Möglichkeit eines Eingriffs von chemischen Substanzen in das hormonelle System wird bei den beiden erstgenannten Mechanismen die Interaktion mit nukleären Rezeptoren bzw. auch eine Interaktion dieser untereinander vorausgesetzt (Swedenborg et al. 2009). Die derzeit am ausführlichsten untersuchte Interaktion von nukleären Rezeptoren ist die der Interaktion des Estrogen-Rezeptors alpha (ER $\alpha$ ) mit dem Arylhydrocarbon-Rezeptor (AhR), die in Abschnitt 1.4 näher beschrieben wird.

\subsection{Estrogen-Rezeptoren und ihre Liganden}

\subsubsection{Endogene Estrogene}

Estrogene gehören neben den Glukokortikoiden, Mineralokortikoiden, Androgenen und Gestagenen zur Gruppe der Steroidhormone, denen das Cholesterin-Grundgerüst sowie die Wirkungsentfaltung über Bindung an spezifische Rezeptoren gemein sind. Die Gruppe der endogenen Estrogene umfasst dabei Estradiol, das hauptsächlich in Ovarien und Hoden gebildet wird sowie dessen Metaboliten Estron und Estriol, welche trotz ebenso hoher Bindungsaffinität an die Estrogen-Rezeptoren eine schwächere agonistische Aktivität als Estradiol besitzen (Kuiper et al. 1997). Estrogene spielen eine Schlüsselrolle in Wachstum, Entwicklung und Funktion von weiblichen und männlichen reproduktiven Organen, Brustdrüse, ZNS, Skelett und kardiovaskulärem System (Kuiper et al. 1997; Couse und 


\section{Einleitung}

Korach 1999). Großen Einfluss haben sie auch auf pathologische Prozesse wie die Entwicklung von Mamma- und Endometriumkarzinomen (Henderson et al. 1988), Osteoporose und Thrombophilie (Henderson et al. 1988; Miller und Duckles 2008).

\subsubsection{Estrogen-Rezeptoren}

Estrogene entfalten ihre Wirkung durch Bindung an die intrazellulär gelegenen EstrogenRezeptoren (ERs), welche als Liganden-induzierbare Transkriptionsfaktoren die zelluläre Proteinsynthese aktivieren. ERs gehören zu der Klasse der Steroidhormonrezeptoren (SHR), die wiederum zusammen mit Schilddrüsen-, Vitamin D- und Retinolsäure-Rezeptoren sowie einer wachsenden Anzahl von Orphan-Rezeptoren (Rezeptoren ohne bisher bekannte endogene Liganden) die Superfamilie der Kernrezeptoren bilden, die eine gemeinsame Grundstruktur aufweisen (Evans 1988; Mangelsdorf et al. 1995; Gronemeyer et al. 2004). Die Bindung von Estradiol an einen ER konnte erstmals von Jensen und Gorski nachgewiesen werden (Toft und Gorski 1966; Jensen und DeSombre 1973). Lange wurde vom Bestehen nur eines Estrogen-Rezeptors (ER, später ER $\alpha$ ) ausgegangen, welcher 1986 für den Menschen kloniert werden konnte (Green S et al. 1986). Ein zweiter Estrogen-Rezeptor (ER $\beta$ ) wurde erst 1996 in den Ovarien und der Prostata von Ratten entdeckt (Kuiper et al. 1996). Dabei ist ER $\beta$ keine Isoform von ER $\alpha$, auch die kodierenden Gene liegen auf zwei verschiedenen Chromosomen (Enmark et al. 1997). Inzwischen sind von den mRNA beider Subtypen zahlreiche natürlich vorkommende Varianten und Mutationen bekannt (Murphy et al. 1997; Petersen et al. 1998).

Der ungebundene Estrogen-Rezeptor liegt im Zytoplasma in einem Heterokomplex mit Heat shock-Proteinen und immunophilin chaperones vor, die eine richtige Proteinfaltung der Hormonbindungsstelle und damit die Ligandenbindung erleichtern (Welshons et al. 1984; Pratt und Toft 1997). Dieser Komplex dissoziiert als Reaktion auf die Bindung von Estrogen oder einem anderen Liganden an die sog. ligand-binding domain des ER, welcher durch eine Konformationsänderung in einen aktiven Zustand versetzt wird (Swope und Korach 2003). Nachfolgend kann der Rezeptor als Homo- (ER $\alpha / E R \alpha)$ oder Heterodimer $(E R \alpha / E R \beta)$ an Estrogen-Rezeptor-spezifische DNA-Sequenzen (estrogen-response element, ERE) in der Promotorregion der Zielgene binden (White und Parker 1998). Die Transkription des Zielgens wird dabei durch die Rekrutierung von Kofaktoren zur Bildung eines Transkriptionskomplexes induziert bzw. gehemmt: Koaktivatoren (wie SRC-1) können über die sog. activation function-2 domain (AF-2) mit dem ER interagieren, welche als Teil der Helix 12 


\section{Einleitung}

nur bei Bindung eines ER-Agonisten (wie E2 oder DES) die passende Konformation aufweist. Durch die Bindung eines antagonistischen Liganden (wie Raloxifen oder ICI 182,780) wird die Konformation der Helix 12 gestört und Korepressoren (wie N-CoR oder SMRT) binden stattdessen an den ER (White und Parker 1998; Nilsson et al. 2001).

Neben diesem klassischen Modell der rezeptorvermittelten Genexpression werden inzwischen weitere molekulare Mechanismen der estrogenen Signalvermittlung diskutiert:

- Liganden-unabhängige Aktivierung von ERs mittels Phosphorylierung durch cAMP- und Wachstumsfaktor-induzierte Kinasen (Kato et al. 1995; Cenni und Picard 1999).

- ERE-unabhängige Aktivierung der Transkription durch Interaktion des Ligandengebundenen ER $\alpha$ mit DNA-gebundenen Transkriptionsfaktoren Sp-1 sowie Fos/Jun (an Ap-1 Bindungsstellen) (Kushner et al. 2000; Saville et al. 2000).

- Mögliche Vermittelung nicht-genomischer schneller Wirkungen von Estradiol über intrazelluläre Signalkaskaden durch Estrogen-Rezeptoren in der Zellmembran (Razandi et al. 2000; Hall et al. 2001; Cheskis et al. 2007).

\subsubsection{Der UV-Filter 4MBC als Xenoöstrogen}

Als Schutz vor den Folgen von akuter und chronischer Sonnenexposition für die Haut durch UVA (320 - 400 nm)- und UVB (290 - 320 nm)-Strahlung wird von Fachgesellschaften die Anwendung von Sonnencremes mit UV-Filtern empfohlen, welche auch in steigendem Maße in anderen Kosmetika und Kunststoffen eingesetzt werden (Schlumpf et al. 2001; Elsner et al. 2006). Während die Prävention von Sonnenbrand, Hautalterung und Nicht-MelanomHauttumoren hierfür weitgehend belegt werden konnte (Gasparro et al. 1998; Green A et al. 1999), bleibt der Effekt im Hinblick auf das maligne Melanom Gegenstand kontroverser Diskussionen (Bigby 1999; Gefeller und Pfahlberg 2002). Neben den rein physikalisch über Reflexion wirksamen UV-Filtern wie Zinkoxid bestehen Sonnencremes aus kosmetisch weniger störenden chemischen UV-Filtern, die in die Haut eindringen und die energiereiche kurzwellige UVA- und UVB-Strahlung absorbieren und in Form von Wärme wieder abgeben sollen. Schlumpf et al. konnten einige dieser chemischen UV-Filter als estrogen wirksam identifizieren, wobei das 4-Methylbenzylidene Camphor (4MBC) die größte Potenz aufweist (Schlumpf et al. 2001). Die Estrogenität in vitro und in vivo konnte bestätigt (Tinwell et al. 2002; Seidlova-Wuttke et al. 2006b) sowie ferner die Induktion der Transkription über die ER-Rezeptoren gezeigt werden (Schreurs et al. 2002; Mueller et al. 2003). Desweiteren werden Einflüsse von 4MBC auf die Entwicklung und die Schilddrüsenfunktion diskutiert 


\section{Einleitung}

(Schlumpf et al. 2004; Seidlova-Wuttke et al. 2006a). Die Aufnahme von UVFiltersubstanzen durch den Menschen erfolgt über die Haut und aufgrund der Bioakkumulation auch über die Nahrungskette (Nagtegaal et al. 1997). Nach der topischen Anwendung von Sonnencremes können UV-Filter in Blut, Urin und Muttermilch nachgewiesen werden (Hany und Nagel 1995; Janjua et al. 2004).

\subsection{Der Arylhydrocarbon-Rezeptor und seine Liganden}

\subsubsection{Der Arylhydrocarbon-Rezeptor}

Der Arylhydrocarbon-Rezeptor (AhR, auch „Dioxin-Rezeptor“) gehört wie die Estrogenrezeptoren zu der Superfamilie der Kernrezeptoren (Gronemeyer et al. 2004). Seine hohe Bindungsaffinität zum 2,3,7,8-Tetrachlordibenzodioxin (TCDD), dem potentesten Induktor des CYP1A1-Enzyms (zuvor als Arylhydrocarbon Hydroxylase bekannt), führte 1976 zu seiner Entdeckung durch Poland et al. (Poland et al. 1976). Die Beobachtung, dass die Bindung von TCDD und vielen anderen organischen Verbindungen (s. 1.3.2) an den AhR primär für deren Toxizität verantwortlich ist (Fernandez-Salguero et al. 1996), machte diesen zu einem Schlüsselfaktor für die zelluläre Antwort auf Umweltchemikalien und zu einem der am intensivsten untersuchten Orphan-Rezeptoren, dessen genaue physiologische Funktion und hochspezifischer endogener Ligand bisher nicht bekannt sind (Beischlag et al. 2008). Aufgrund seiner charakteristischen Struktur zählt der AhR zu den basic Helix-LoopHelix/Per-Arnt-Sim (bHLH/PAS)-Liganden-aktivierten Transkriptionsfaktoren, welche als Homo- oder Heterodimere an die DNA binden. Die bHLH-Domäne vermittelt dabei die DNA-Bindung und primäre Dimerisation, die PAS-Domäne die sekundäre Dimerisation mit einem speziellen bHLH/PAS-Partnerprotein (Pongratz et al. 1998). Bei dem AhR fungiert als solcher der Aryl Hydrocarbon Nuclear Translocator (ARNT), der in fast allen Geweben exprimiert wird, stets im Zellkern lokalisiert ist und sowohl Homodimere als auch Heterodimere mit anderen bHLH/PAS-Proteinen bildet (Kewley et al. 2004). In der Ratte findet sich die höchste AhR-Expression in Lunge, Thymus, Niere und Leber (Carver et al. 1994). 


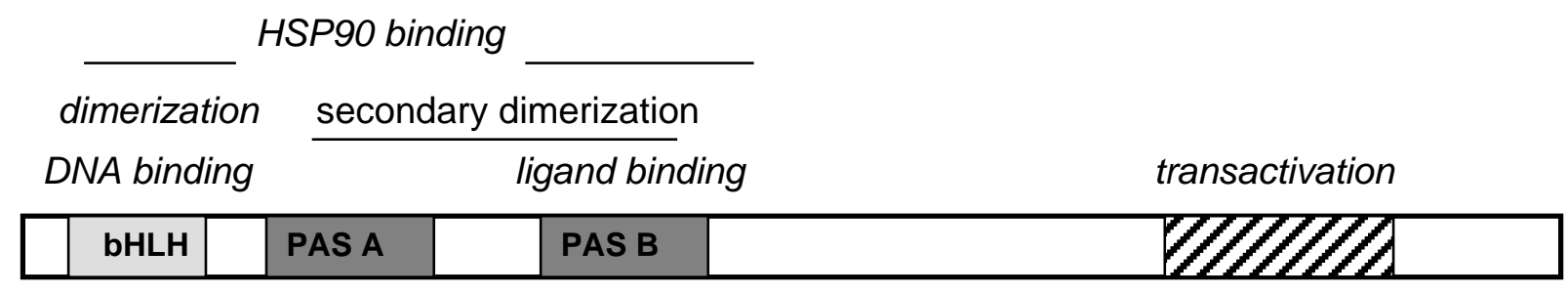

Abbildung 1: Funktionelle Domänen des Arylhydrocarbon-Rezeptors (mod. nach Kewley et al. 2004, s. S. 191)

\subsubsection{Der AhR-Signalweg}

Unter der Abwesenheit von Liganden liegt der AhR im Zytoplasma in einem Heterokomplex aus dem Chaperon Heat shock-Protein 90 (HSP90) und dem Phosphoprotein p23 sowie dem Hepatitis B Virus-assoziierten Protein 2 (XAP2) vor, die zusammen den Erhalt der korrekten Proteinfaltung und des Ligandenbindungsvermögens des AhRs bewirken (Beischlag et al. 2008). Nach der Bindung eines Liganden an den AhR transloziert dieser in den Zellkern und bildet dort mit seinem Partnerprotein ARNT einen Heterodimer und DNA-Bindungskomplex. Da das HSP90 an den AhR über die bHLH- und PAS B-Domänen bindet, diese jedoch für die Dimerisierung mit dem ARNT zur Verfügung stehen müssen, dissoziiert zuvor der AhR/HSP90-Komplex (Heid et al. 2000). Hierbei wird ebenso das $N$-terminal nuclear localisation signal (NLS) exponiert, welches den Transport in den Nukleus vermittelt (Pongratz et al. 1992; Ikuta et al. 1998). Dort bindet der Liganden-gebundene AhR/ARNTHeterodimer an xenobiotic responsive elements (XREs, auch dioxin responsive elements, DREs), welche sich in der Promotor-Region der TCDD-responsiven Gene befinden. Nach der Rekrutierung von Transkriptionskofaktoren wird die Transkription der AhR-Zielgene, wie beispielsweise die des Xenobiotika metabolisierenden Enzyms CYP1A1, initiiert (Israel und Whitlock 1983). Durch die Induzierung von verschiedenen Enzymen der Phase I und II der Biotransformation, der „AhR gene battery“ (u.a. CYP1A1, CYP1A2, CYP1B1), wird die Elimination der AhR-Liganden erleichtert. Auf dieses Weise wird allerdings auch die Produktion toxischer Metabolite gefördert und letztlich die schwere Toxizität der Vergiftungen mit Dioxinen und polychlorierte Biphenylen vermittelt (Shimizu et al. 2000). 


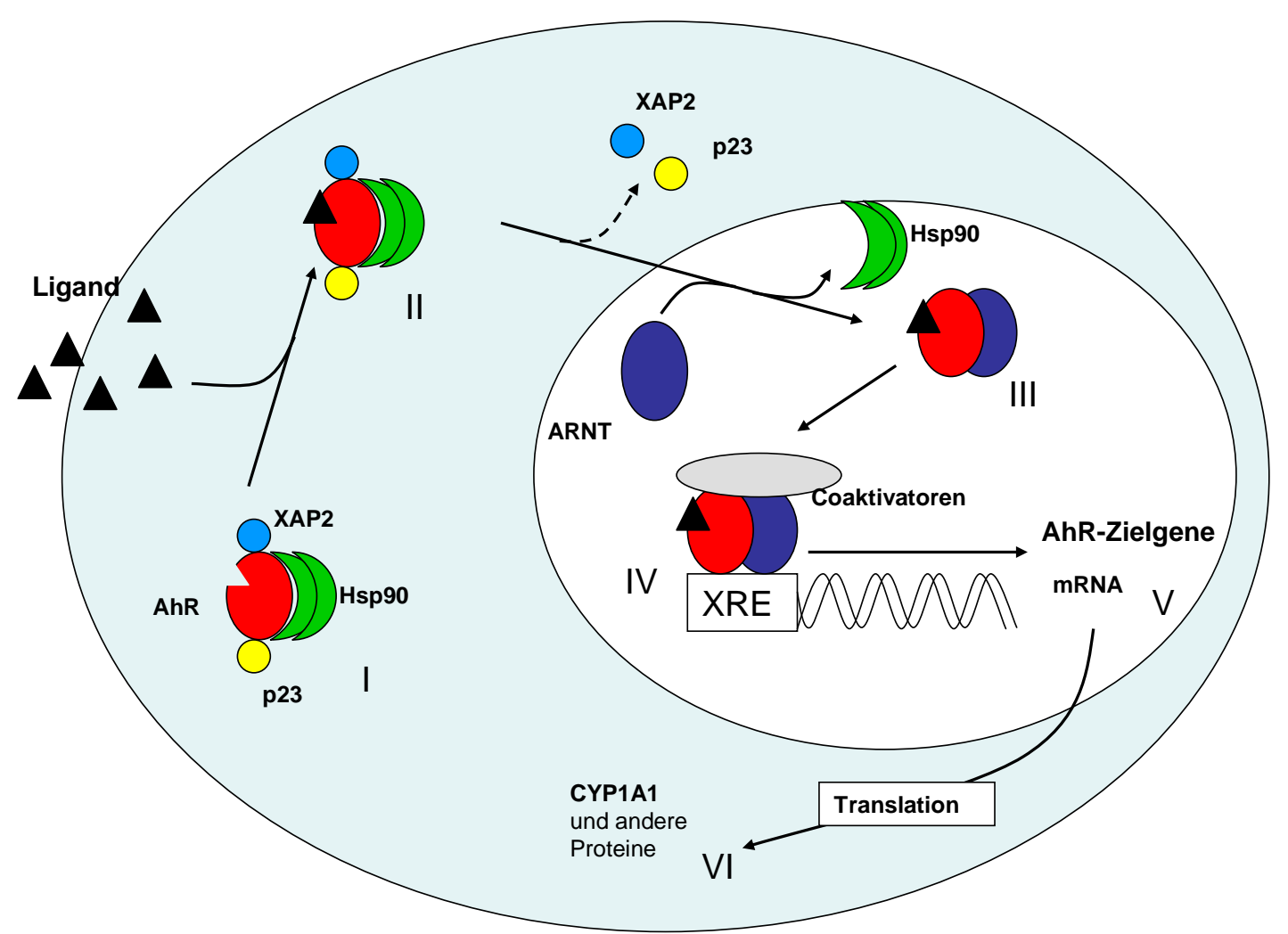

Abbildung 2: Der AhR-Signalweg (mod. nach: Kewley et al. 2004, s.S. 193; Swedenborg et al. 2009 , s.S. 2-3) Transkriptionsinduktion von AhR-Zielgenen unter Anwesenheit von Liganden. Unter Abwesenheit von AhR-Liganden liegt der AhR im Zytoplasma in einem Heterokomplex mit den Chaperonen Hsp90 sowie XAP2 und p23 vor (I). Nach der Bindung eines durch die Zellmembran diffundierten Liganden (II) dissoziiert der Multiproteinkomplex. In den Zellkern transloziert, bildet der AhR mit seinem Partnerprotein ARNT einen Heterodimer (III), welcher zusammen mit Coaktivatoren an xenobiotic response elements in der PromotorRegion der AhR-Zielgene bindet und dort deren Transkription initiiert (IV, V). Enzyme der „AhR gene battery“ wie beispielsweise CYP1A1 werden induziert (VI).

\subsubsection{Liganden des AhR}

Als potentester Ligand des AhR gilt das 2,3,7,8-Tetrachlordibenzodioxin (TCDD), welches als bekanntester Vertreter der polychlorierten Dibenzo-p-Dioxine und Dibenzofurane (PCDDs/PCDFs) zusammen mit den polychlorierten Biphenylen (PCBs) die Klasse der polyhalogenierten aromatischen Kohlenwasserstoffe (PHAKs) bildet (Poland und Knutson 1982). Ebenso gehören die polyzyklischen aromatischen Kohlenwasserstoffe (PAKs) zu den Induktoren der AhR-Zielgene. Zu den PAKs zählen unter anderem 3-Methylcholanthren (3MC), Benzo[a]pyren (BaP) und Benzoflavone. Während die PHAKs eine sehr hohe Bindungsaffinität zum AhR aufweisen (im Bereich von pM bis nM), ist die Affinität der PAKs signifikant geringer (nM bis $\mu \mathrm{M}$ ) (Denison et al. 2002). Als „Modell-Dioxin“ wurde TCDD am intensivsten untersucht, so dass dessen Toxizität als Referenzwert für die akute 


\section{Einleitung}

Toxizität der anderen Mitglieder der PHAKs gilt. Stoffgemische aus verschiedenen PHAKs werden über das System der Toxizitätsäquivalente (TEQ) zu TCDD in Relation gesetzt (Safe 1990; Ahlborg et al. 1992). Es muss allerdings der Umstand berücksichtigt werden, dass PHAKs häufig in sehr geringen Konzentrationen und fast ausschließlich in Stoffgemischen vorkommen und damit die Risikoabschätzung für den Menschen und das Ökosystem wesentlich erschwert wird (Safe 1998; Van den Berg et al. 1998).

Neben der Bindung des AhR an Xenobiotika konnten zahlreiche Studien auch die Interaktion von natürlich vorkommenden Chemikalien und deren Metaboliten wie Indol-3-Carbinol, Curcumin und Quercetin mit dem AhR nachweisen (Beischlag et al. 2008).

Die Beobachtungen an AhR-Knockoutmäusen mit ausgeprägten Störungen der Leber- und Immunsystementwicklung (Fernandez-Salguero et al. 1995) sowie die Beeinflussung der Expression zahlreicher Gene inklusive des ER $\alpha$ weisen auf eine weitreichende Funktion des AhR in der normalen Physiologie auch in Abwesenheit exogener Liganden hin (Tijet et al. 2006).

\subsubsection{TCDD}

TCDD wird als einer der giftigsten je vom Menschen hergestellten Stoffe angesehen, welcher als Verunreiniger im Entlaubungsmittel Agent Orange während des Vietnamkriegs sowie bei einem Chemieunfall im italienischen Seveso 1976 mit seinen dramatischen Folgen für Mensch und Tier allgemeine Bekanntheit erlangte (Bertazzi et al. 1998; Schecter et al. 2002). Seit der industriellen Revolution werden PHAKs als Nebenprodukte bei Verbrennungsreaktionen (insbesondere Abfallverbrennung), bei der Papierherstellung mit chlorhaltigen Bleichprozessen, Herstellung von Pflanzenschutzmitteln, metallurgischen Prozessen und durch Abgase von Benzinmotoren in großem Umfang freigesetzt. Natürliche Prozesse wie Waldbrände oder mikrobieller Abbau tragen neben den anthropogenen Emissionen nur mit einem minimalen Anteil zur Dioxinbelastung der Umwelt bei (Schecter et al. 2006). Obwohl seit den 80-er Jahren die industrielle Emission von PHAKs drastisch reduziert wurde, gelangen diese nach wie vor über Verbrennungen, kontaminierte Sedimente und PCB-haltige Materialien in das Ökosystem (Ahlborg et al. 1992). Desweiteren führt die fast vollkommen planare hydrophobe Struktur zu einer sehr hohen Langlebigkeit und Biopersistenz dieser Stoffe, die sich ubiquitär im aquatischen und terrestrischen Ökosystem finden lassen. Vom Menschen werden sie wegen ihrer Ansammlung im Fettgewebe über die tierische Nahrungskette, hierunter besonders Fische und Muttermilch, aber auch über das Trinkwasser 


\section{Einleitung}

und durch Zigarettenrauch aufgenommen (Muto und Takizawa 1989; Lofroth und Zebuhr 1992; Schecter et al. 2001).

\subsection{Interaktion von ERo und AhR}

\subsubsection{Hypothesenbildung/Entdeckung}

Die akute, letztendlich auch letale, Exposition eines Lebewesens gegenüber TCDD und verwandten Stoffe zeigt eine Reihe von sehr charakteristischen Reaktionen wie Gewichtsverlust, Chlorakne, Immunsuppression und Reduktion des lymphatischen Gewebes, Porphyrie und Hepatotoxizität, Karzinogenität und reproduktive Toxizität (Poland und Knutson 1982). Dabei variieren das dosisabhängige Auftreten der Reaktionen und die letale Dosis unter den verschiedenen Spezies in sehr unterschiedlichem Maße. Die Beobachtungen von signifikanten Unterschieden zwischen männlichen und weiblichen Ratten bei chronischer Exposition gegenüber TCDD bezüglich des Auftretens von Tumoren sowie die deutlich reduzierte Inzidenz von den estrogensensiblen Mamma- und Endometriumkarzinomen unter TCDDBehandlung bildeten die Grundlage für zahlreiche Studien über die Gewebespezifität eines inhibitorischen „AhR-ER crosstalks“ und die Mechanismen dieser Reaktion (Kociba et al. 1978; Safe und Wormke 2003).

\subsubsection{Mechanismen der Interaktion}

Folgende Mechanismen der Inhibition der ER-Zielgene durch TCDD und dessen Aktivierung des AhR (inhibitorische AhR-ER $\alpha$-Interaktion) wurden beschrieben:

- Gesteigerter Metabolismus von Estradiol durch TCDD-induzierte Expression von CYP1A1 und CYP1B1 (Spink et al. 1992)

- TCDD-induzierte Degradation von endogenem ER $\alpha$ durch Proteasomen mittels Ubiquitinierung (Wormke et al. 2003; Ohtake et al. 2007)

- Kompetition von AhR und ER $\alpha$ um gemeinsame Coaktivatoren und um ARNT (Reen et al. 2002; Ruegg et al. 2008)

- Inhibition der ER-Genaktivität über Bindung des aktivierten AhR an inhibitory XREs (iXREs), welche den ER-Promotorregionen benachbart sind (Safe und Wormke 2003) 


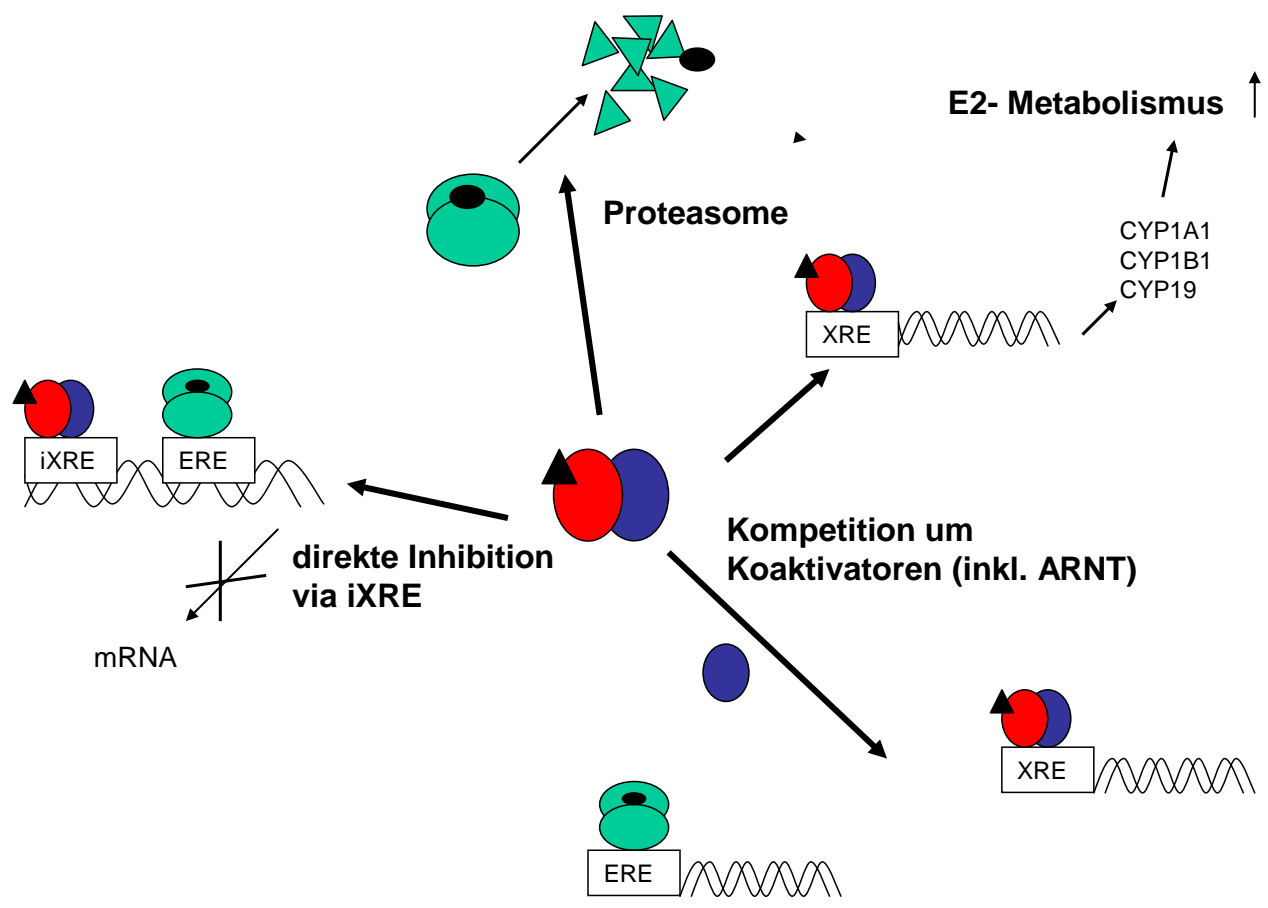

Abbildung 3: Mögliche Mechanismen einer inhibitorischen AhR-ERa-Interaktion (mod. nach Matthews und Gustafsson 2006, s.S. 2).

\subsection{Ziel der Arbeit und Methodenwahl}

Da die bisherigen weitreichenden Untersuchungen $\mathrm{zu}$ einer AhR-ER $\alpha$-Interaktion hauptsächlich die Auswirkungen der AhR-Aktivierung durch Xenobiotika auf den ER $\alpha$ Signalweg fokussierten, soll in dieser Arbeit die Wirkung von Estradiol und dem Xenoöstrogen 4MBC sowie anderen Steroidhormonen auf den AhR-Signalweg untersucht werden. Die bislang durchgeführten Untersuchungen bezüglich dieser Fragestellung weisen auf eine Hemmung der durch AhR-Liganden induzierten CYP1A1-Genexpression durch Estradiol und estrogene Substanzen hin. Dabei werden direkte Interaktionen des aktivierten ER $\alpha$ mit dem AhR auf transkriptioneller Ebene als ursächlich für eine Hemmung der AhRZielgene angesehen (Beischlag und Perdew 2005). Diese Beobachtung konnte jedoch unter unterschiedlichen Untersuchungsbedingungen nicht grundsätzlich gezeigt werden (Wormke et al. 2000). Die Hypothese der Estradiol-induzierten Hemmung der AhR-Zielgene auf transkriptioneller Ebene bleibt daher weiter Gegenstand der aktuellen Disskussion und soll hier mittels der im Folgenden aufgeführten Testmethoden verifiziert werden. Dabei wird 


\section{Einleitung}

zusätzlich das Xenoöstrogen 4MBC als weiterer möglicher Aktivator des ER $\alpha$ Verwendung finden.

Die Ausgangsmethode in dieser Arbeit ist ein weit verbreiteter und als valide Testmethode verwendeter Enzym-Assay, der EROD-Assay, bei dem die Induktion des CYP1A1-Enzyms als Endpunkt des AhR-Signalweges ausgewertet wird. Um die Wirkung des Estradiols aufzuheben, wird eine Kontrolle mit dem Estrogenrezeptor-Antagonisten ICI 182,780 durchgeführt. Zur Diskrimination zwischen einer Veränderung der Genexpression und einer möglichen Veränderung der posttranslationalen Modifikation des „AhR-Signalweg-Endproduktes“ CYP1A1 werden PCR-Untersuchungen in vitro sowie auch in einem Tierversuch in vivo vorgenommen. Anschließend wird der EROD-Assay an einem Proteinkonzentrat der verwendeten Zellkultur wiederholt. Im Folgenden werden die Grundlagen der verwendeten Methoden dargestellt.

\subsubsection{EROD-Assay}

Der 7-Ethoxyresorufin-O-deethylase-(EROD)-Assay dient als In-Vitro-Screening-Assay der schnellen und einfachen Identifizierung von xenobiotisch wirksamen Substanzen, welche wie Dioxin an den AhR-Rezeptor binden und über den nachfolgenden Signalweg eine erhöhte Genexpression der CYP1A-Isoformen (CYP1A1, CYP1A2) und damit Enzyminduktion bewirken (Kennedy und Jones 1994; Whyte et al. 2000). Die durch 3MC (einem häufig verwendeten Standard-Karzinogen und AhR-Ligand) induzierte Aktivität des CYP1A1Enzyms in einer intakten Hepatom-Zelllinie soll hier als Positivkontrolle fungieren. Die Wirkung des zusätzlich zugefügten Estradiols, des Xenoöstrogens 4MBC sowie anderer estrogener Substanzen soll dagegen verglichen werden.

\subsubsection{Auswirkung von Estradiol und 4 MBC auf die In-Vitro-Genexpression}

Da die Fragestellung der Arbeit auf die Interaktion zwischen dem AhR- und ER $\alpha$-Rezeptor zielt, wird die mögliche Veränderung der Genexpression des AhR-Zielgens CYP1A1 sowie die der nukleären Rezeptoren selbst durch den Zusatz von Estrogen und dem Xenoöstrogen 4MBC untersucht. Dabei wird ebenso wie beim EROD-Assay die induzierte Genexpression der Zelllinie durch 3MC als Positivkontrolle herangezogen. 


\subsubsection{Auswirkungen von Estradiol und 4MC auf die In-Vivo-Genexpression}

In einem Tierexperiment soll ein möglicher Effekt von Estradiol und 4MBC auf die Genexpression von CYP1A1, AhR und ARNT zu den Ergebnissen der In-Vitro-Testreihe verglichen werden. Dazu werden Wildtyp-Mäusen 3MC sowie Kombinationen mit Estradiol und 4MBC oral appliziert und nach drei Tagen die hepatische Genexpression gemessen. Anhand von Serumwerten wird die dabei die orale Bioverfügbarkeit des applizierten Estradiols kontrolliert.

\subsubsection{EROD-Assays am Zellhomogenat}

Die ursprünglich entwickelte Methode von Burke und Mayer umfasste den EROD-Assay an Mikrosomen von Ratten- und Hamsterlebern, um eine Induktion des AhR-Signalweges und des CYP1A1 nachzuweisen. Bei Mikrosomen handelt es sich um Fragmente des endoplasmatischen Retikulums, welche bei Homogenisierung von Gewebe entstehen. Im abzentrifugierten Anteil sind so insbesondere die CYP-Enzyme gebunden. Um die Reaktion des CYP1A1-Enzyms mit den zugefügten Substanzen (Estradiol, 4MBC und andere estrogene Substanzen) möglichst isoliert betrachten zu können, soll nach Induktion der CYP1A1Aktivität in der Zellkultur ein Zellhomogenat hergestellt, dann die Substanzen hinzugefügt und abschließend der EROD-Assay durchgeführt werden. Die Ergebnisse sollen nachfolgend mit denen des EROD-Assays an den intakten Zellen verglichen werden und somit eine engere Eingrenzung der möglichen Interaktionspunkte von Estradiol und 4MBC auf die AhRSignalkaskade möglich machen. 


\section{Material und Methoden}

\section{$2.1 \quad$ Testsubstanzen}

\section{$17 \boldsymbol{\beta}$-Estradiol (E2)}

Substanzname: 1,3,5-Estratriene-3,17 $\beta$-diol

Summenformel: $\mathrm{C}_{18} \mathrm{H}_{24} \mathrm{O}_{2}$

Molare Masse: $272.38 \mathrm{~g} / \mathrm{mol}$

CAS-Nummer: 50-28-2

bezogen von: Sigma, Schnelldorf

Abbildung 4: Strukturformel von 17ß-Estradiol

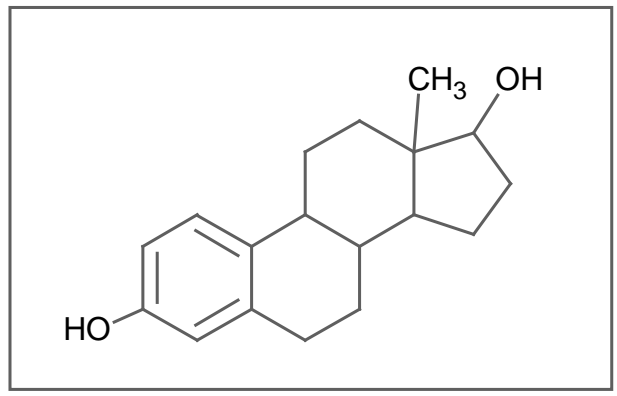

\section{$\beta$-Estradiol 17-valerat (E2V)}

E2-Depot-Derivat für die orale Applikation

Substanzname: Estra-1,3,5(10)-trien-3, 17ß-diol, 17-pentanoat

Summenformel: $\mathrm{C}_{23} \mathrm{H}_{32} \mathrm{O}_{3}$

Molare Masse: $356.50 \mathrm{~g} / \mathrm{mol}$

CAS-Nummer: 979-32-8

bezogen von: Sigma, Schnelldorf

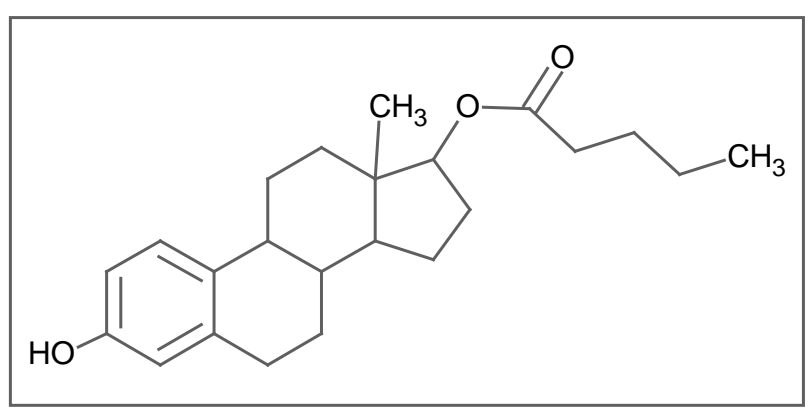

Abbildung 5: Strukturformel von ß-Estradiol 17-valerat

\section{3-Methylcholanthren (3MC)}

Substanzname: 3-Methylcholanthren

Summenformel: $\mathrm{C}_{21} \mathrm{H}_{16}$

Molekulargewicht: $268.35 \mathrm{~g} / \mathrm{mol}$

CAS-Nummer: 56-49-5

bezogen von: Sigma, Schnelldorf

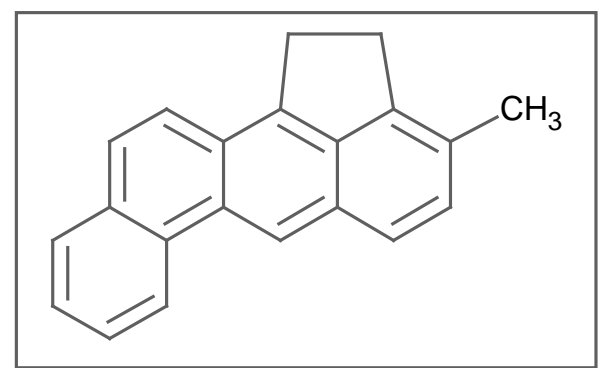

Abbildung 6: Strukturformel von 3-Methylcholanthren 


\section{4-Methylbenzylidene Camphor (4MBC)}

Substanzname: (3E)-1,7,7-Trimethyl-3-[(4-methylphenyl)methylene]-2-norbornanone

Summenformel: $\mathrm{C}_{18} \mathrm{H}_{22} \mathrm{O}$

Molekulargewicht: $254.37 \mathrm{~g} / \mathrm{mol}$

CAS-Nummer: 36861-47-9

bezogen von: Merck, Darmstadt

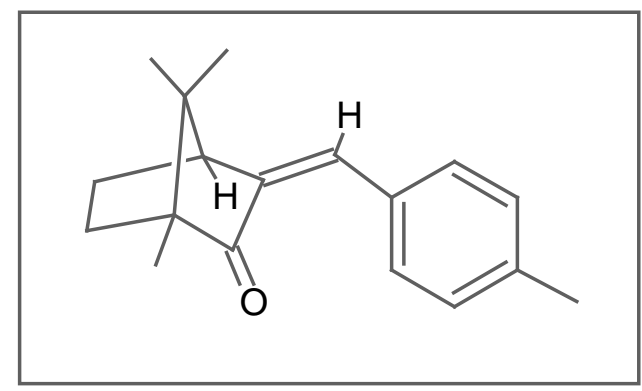

Abbildung 7: Strukturformel von 4-Methylbenzylidene Camphor

\subsection{Chemikalien und Reagenzien}

Soweit nicht anders angegeben, wurden alle aufgeführten Chemikalien in der höchsten erhältlichen Reinheitsstufe verwendet.

$17 \alpha$-Estradiol

7-Ethoxyresorufin

Bradford Reagenz, Protein Assay

Corticosteron

Dimethylsulfoxid (DMSO)

Dicumarol

D-Isocitrat, Monokaliumsalz

DMEM

dNTP-Mix

Fetales Kälberserum (FKS)

EDTA, 0.5M

Estriol

Estron

Genistein

Glutaraldehyd, $25 \%$ in $\mathrm{H}_{2} \mathrm{O}_{\text {bidest }}$

ICI 182,780 (ICI)

Isocitrat-Dehydrogenase

Magnesiumchlorid $\left(\mathrm{MgCl}_{2}\right)$
Sigma, Schnelldorf

Fluka, Neu Ulm

BioRad, München

Serva, Heidelberg

Merck, Darmstadt

Sigma, Schnelldorf

Fluka, Schnelldorf

Gibco, Karlsruhe

Invitrogen, Karlsruhe

Biochrom, Berlin

Gibco, Karlsuhe

Merck, Darmstadt

Sigma, Schnelldorf

Roth, Karlsruhe

Sigma, Schnelldorf

Tocris, Avonmouth, UK

Sigma, Schnelldorf

Merck, Darmstadt 
MEM Sodium Pyruvat, 100 mM

M-MLV Reverse Transcriptase RNase H Minus

$\mathrm{NADP}^{+}$

PBS, 10x

Pen/Strep-Lösung, 1\%, 10.000 U Penicillin/ml, $10 \mathrm{mg}$ Streptomycin/ml in 0,85 \% Kochsalzlösung

Plasma-Gammaglobulin, Std I

Progesteron

Protease Inhibitor Cocktail, Complete Mini, EDTA frei

Raloxifenhydrochlorid

Recombinant RNasin ${ }^{\circledR}$ Ribonuclease Inhibitor Resorufin

Salzsäure ( $\mathrm{HCl})$

Saccharose

Succhrose

Taqman-PCR-Mastermix, qPCR ${ }^{\mathrm{TM}}$ Core Kit

Testosteron

Tris

Trypsin-EDTA, 0.05\%

Uracil-N-glycosylase

Velcorin ${ }^{\circledR}$ (Dimethylpyrocarbonat/DMDC)
Gibco, Karlsruhe

Promega, Mannheim

Sigma, Schnelldorf

Gibco, Karlsruhe

Gibco, Karlsruhe

BioRad, München

Sigma, Schnelldorf

Roche, Mannheim

Sigma, Schnelldorf

Promega, Mannheim

Sigma, Schnelldorf

Merck, Darmstadt

Merck, Darmstadt

Sigma, Schnelldorf

Eurogentec, Seraing, Belgien

Merck, Darmstadt

Roth, Karlsruhe

Gibco, Karlsruhe

Eurogentec, Seraing, Belgien

Bayer, Leverkusen

\section{$2.3 \quad$ Verbrauchsmaterialien}

96 Well Multiply®-PCR-Plate

Deckelketten, Biosphere ${ }^{\circledR} 0.2 \mathrm{ml}$

Fluoreszenzplatten, FluoroNunc F96

RNeasy® Minikit

Zellschaber, Falcon
Sarstedt, Nümbrecht

Sarstedt, Nümbrecht

Nunc, Wiesbaden

Qiagen, Hilden

Omnilab, Mettmenstetten 


\section{$2.4 \quad$ Lösungen}

\subsubsection{Zellkultur}

$\begin{array}{ll}\text { Permanentkultur-Medium (PKM): } & 500 \mathrm{ml} \text { DMEM } \\ & 50 \mathrm{ml} \text { FKS } \\ & 5 \mathrm{ml} \text { Pyruvat }(100 \mathrm{mM}) \\ & \text { Lagerung bei } 4^{\circ} \mathrm{C} \\ & \\ & 10 \mathrm{mM} \text { Tris } \\ & 250 \mathrm{mM} \text { Succhrose } \\ & \text { ad } 100 \mathrm{ml} \mathrm{H} \mathrm{O}_{\text {bidest }} \\ & 1 \text { Tablette Protease Inhibitor Cocktail pro } 10 \mathrm{ml} \\ \text { Tris-Succhrose-Puffer: } & \text { pH } 7,4 \\ & \text { Lagerung bei } 4^{\circ} \mathrm{C}\end{array}$

\subsubsection{Molekularbiologische Arbeiten}

$\begin{aligned} \mathrm{H}_{2} \mathrm{O}_{\text {velc }} \text { (Velcorinwasser): } & 0,1 \mathrm{ml} \text { Velcorin }{ }^{\circledR} \\ & \text { ad } 100 \mathrm{ml} \mathrm{H}_{2} \mathrm{Obidest} \\ & 4 \mathrm{~h} \text { bei RT inkubieren lassen } \\ & \text { autoklavieren }\end{aligned}$

\section{$2.5 \quad$ Zellkultur}

\subsubsection{Kultivierung}

Die Zelllinie H4IIE (ATCC, Manassas, VA, USA) wurde in $75 \mathrm{~cm}^{2}$-Flaschen auf Permanentkultur-Medium (PKM) bei $37^{\circ} \mathrm{C}, 10 \% \mathrm{CO}_{2}$ und einer relativen Luftfeuchtigkeit von 95\% inkubiert. Um Kontaminationen zu vermeiden, wurde das Kulturmedium mit einer 1\% Pen/Strep-Lösung versetzt und die Zellkultur täglich mikroskopisch kontrolliert. Ein Mediumwechsel erfolgte alle 3 Tage. Im Abstand von 7 Tagen wurden die Zellen passagiert. Dazu wurde das Medium vorsichtig vom Zellrasen abgesaugt, dieser zweimal mit PBS gewaschen und mit ca. $6 \mathrm{ml}$ Trypsin-EDTA-Lösung bedeckt. Nach 5 min Inkubation bei $37^{\circ} \mathrm{C}$ wurde der Fortschritt der Trypsinierung lichtmikroskopisch verfolgt und bei stark anhaftenden Zellen die Ablösung mit leichten Stößen an die Kulturflasche unterstützt. Die Trypsin-Lösung mit den abgelösten Zellen wurde zur Inaktivierung des Trypsins in $10 \mathrm{ml}$ serumhaltiges PKM gegeben und die Flasche einmal mit Medium nachgespült. Anschließend wurde die Zellsuspension bei 1200 Upm (300g) für 10 min bei RT zentrifugiert (Labofuge GL, Heraeus Christ, Hanau). Nach zweimaligem Waschen mit PBS wurde die Zellzahl mit einer NeubauerZählkammer (Brand, Wertheim) bestimmt. Die Aussaat der Zellen erfolgte mit 20000 Zellen 
pro ml Medium. Dabei wurde die Kultur bis maximal Passage 20 benutzt, um Veränderungen der Zelleigenschaften im Verlauf der Assays auszuschließen (Whyte et al. 2004). Aufgrund dessen wurden frühe Passagen der Zelllinie als Kryokulturen mit $1 * 10^{6}$ Zellen in $1 \mathrm{ml} 10 \%$ DMSO in FKS zunächst in einem Styroporbehälter bei $-70^{\circ} \mathrm{C}$ über Nacht eingefroren und danach in einem Tank mit flüssigem Stickstoff gelagert.

Zum Anlegen einer neuen Zellkultur wurden diese Aliquots in einem $37^{\circ} \mathrm{C}$ warmen Wasserbad angetaut und der Inhalt sofort in $15 \mathrm{ml}$ PKM überführt. Nach zweimaligem

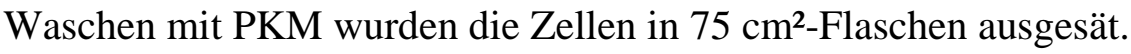

\subsubsection{EROD-Assay}

Die Bestimmung der 7-Ethoxyresorufin-O-deethylase (EROD)-Aktivität dient als Maß für die CYP1A1-Induktion durch Dioxin verwandte Xenobiotika über die Bindung an den cytosolischen Arylhydrocarbon-Rezeptor (AhR). Die Substratreaktion nach Burke und Mayer (Burke MD und Mayer 1974) besteht aus der CYP1A1-katalysierten oxidativen Desalkylierung von 7-Ethoxyresorufin zu Resorufin (Whyte et al. 2004). Durch den Zusatz von Dicumarol wird die Reduktion des gebildeten Resorufins durch Oxidoreduktasen inhibiert (Lubet et al. 1985), so dass die Resorufinmenge bei der anschließenden fluorometrischen Messung als der CYP1A1-Aktivität proportional angesehen werden kann.<smiles>CCOc1ccc2nc3ccc(=O)cc-3oc2c1</smiles>

7-Ethoxyresorufin

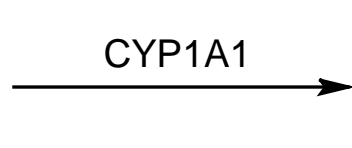<smiles>O=c1ccc2nc3ccc(O)cc3oc-2c1</smiles>

Resorufin

\section{Abbildung 8: Oxidative Desalkylierung von 7-Ethoxyresorufin zu Resorufin}

Für den EROD-Assay wurde die Rattenhepatom-Zelllinie H4IIE verwendet, da sich diese durch gute Kultivierungseigenschaften und eine niedrige basale CYP1A1-Aktivität bei gleichzeitiger hoher Empfindlichkeit auf PAKs auszeichnet (Benedict et al. 1973). Pitot etablierte sie als kontinuierliche Zelllinie aus dem Reuber H-35 Hepatom (Pitot et al. 1964).

Der EROD-Assay wurde nach Clemons (Clemons et al. 1997) durchgeführt. Dazu wurden die H4IIE-Zellen in PKM mit 10000 Zellen pro well in 96-well-Platten ausgesät und für 48 h bei $37^{\circ} \mathrm{C}, 10 \% \mathrm{CO}_{2}$ und einer relativen Luftfeuchtigkeit von 95\% inkubiert. Zur Belastung der 
Zellen wurde das Medium durch frisches ersetzt, dem die in DMSO gelösten Testsubstanzen in Verdünnungsreihen mit Medium zugeben wurden. Zusätzlich enthielt jeder Assay eine Lösungsmittelkontrolle von DMSO („Basal“) in der niedrigsten Verdünnung der Substanzen E2 und 4MBC sowie eine Positivkontrolle mit 3-Methylcholanthren (3MC) $1^{*} 10^{-6} \mathrm{M}$. Zudem wurden Assays mit dem Estrogen-Rezeptor-Antagonisten ICI $182,780 \quad 1^{*} 10^{-6} \mathrm{M}$ in Koinkubation durchgeführt. Nach 48-stündiger Inkubation wurde das Medium abgesaugt und die Zellen pro well mit $50 \mu \mathrm{l} 10 \mu \mathrm{M}$ Dicumarol (aus einer $1 \mathrm{mM}$ Stammlösung, in Ethanol) und $50 \mu \mathrm{l} 4 \mu \mathrm{M}$ Ethoxyresorufin (aus einer $400 \mu \mathrm{M}$ Stammlösung, in Ethanol), jeweils in PBS verdünnt, versetzt. Die Reaktion wurde nach 30 min Inkubation bei $37^{\circ} \mathrm{C}$ mit $200 \mu \mathrm{l}$ 96\% Ethanol/well gestoppt. Jeweils $200 \mu \mathrm{l}$ der Lösungen wurden in schwarze 96-wellFluoreszenzplatten überführt und bei $530 \mathrm{~nm}$ Anregung und $590 \mathrm{~nm}$ Emission in einem Fluorometer (Synergy HT, BioTek, Bad Friedrichshall mit Kineticalc4 Ver. 3.4, BioTek, Bad Friedrichshall) gemessen. Zur Bestimmung der Produktkonzentrationen wurde eine Standardkurve aus sechs Standardpunkten verwendet, welche aus einer $2,5 \mu \mathrm{M}$ Resorufinlösung in 70\% Ethanol in 1:2-Verdünnungen in PBS erstellt wurden.

\subsubsection{Homogenatgewinnung aus H4IIE-Zellen}

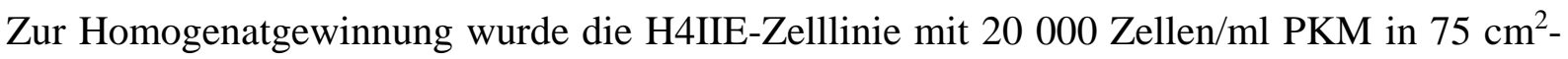
Flaschen ausgesät. Nach 7 Tagen erfolgte ein Mediumwechsel, wobei das neue Medium mit $10^{-6} \mathrm{M}$ 3MC zur CYP1A1-Induktion versetzt wurde. Anschließend wurde nach $48 \mathrm{~h}$ das Medium abgesaugt, die Flaschen zweimal mit gekühltem PBS gewaschen und der Zellrasen in $5 \mathrm{ml}$ gekühltem PBS mit Hilfe eines Einmal-Zellschabers suspendiert. Zusammen mit weiteren $5 \mathrm{ml}$ PBS zum Nachspülen der Flaschen wurden die Zellsuspensionen jeweils aus zwei Kulturflaschen in einem Falcon sofort auf Eis gelagert. Nach 5 min Kühlung erfolgte die Abzentrifugation der Zellen bei 2600 Upm (1000g) für 10 min bei RT (Labofuge GL, Heraeus Christ, Hanau), der Überstand wurde abgesaugt und das Pellet in $1600 \mu \mathrm{l} 10 \mathrm{mM}$ TrisSucchrose-Puffer mit Protease Inhibitor erneut suspendiert. Auf Eis gelagert wurde die Suspension zweimal 10 sec mit einer Ultraschallsonde (Cell Disruptor Micro Tip, Sonifier ${ }^{\circledR}$ B12, Branson Instruments, Danbury, CT; USA) beschallt. Die Zellaufbrechung wurde im Lichtmikroskop kontrolliert und die Zelltrümmer anschließend mit 8500 Upm (6000g) 10 min bei $4^{\circ} \mathrm{C}$ abzentrifugiert (RC-5 Superspeed Refrigerated Centrifuge mit SS34 Rotor, Sorvall Instruments, Bad Homburg). Der Überstand wurde bei $-20^{\circ} \mathrm{C}$ eingefroren. 


\subsubsection{Protein-Bestimmung nach Bradford}

Die Proteinkonzentration der Zellhomogenate wurde anhand des Bradford-Assays (Bradford 1976) bestimmt. Hierzu wurden Verdünnungen einer Überstandsprobe von 1:2, 1:10 und 1:20 mit $\mathrm{H}_{2} \mathrm{O}_{\text {bidest }}$ erstellt und jeweils $10 \mu \mathrm{l}$ in Duplets in einer 96-well-Platte mit $200 \mu \mathrm{l}$ einer 1:5 Verdünnung des Bradford Reagenzes in $\mathrm{H}_{2}$ Obidest versetzt. Nach 5 min Inkubation bei RT wurde die Extinktion bei $590 \mathrm{~nm}$ mit einem Spectra ELISA Reader gemessen. Eine Standardkurve zur Konzentrationsbestimmung wurde mit 100, 200, 400, 600, 800 und 1000 $\mu \mathrm{g} / \mathrm{ml}$ bovinem Plasma-Gammaglobulin erstellt.

\subsubsection{EROD-Assay mit Zellhomogenat}

Bei der Bestimmung der 7-Ethoxyresorufin-O-deethylase (EROD)-Aktivität (s. 2.5.2) im H4IIE-Zellhomogenat wurde zur kontinuierlichen Bereitstellung von Reduktionsäquivalenten für die EROD-Reaktion ein Isocitrat-Dehydrogenase/Isocitrat-System eingesetzt, welches das gebildete $\mathrm{NADP}^{+}$zu NADPH regenerierte.

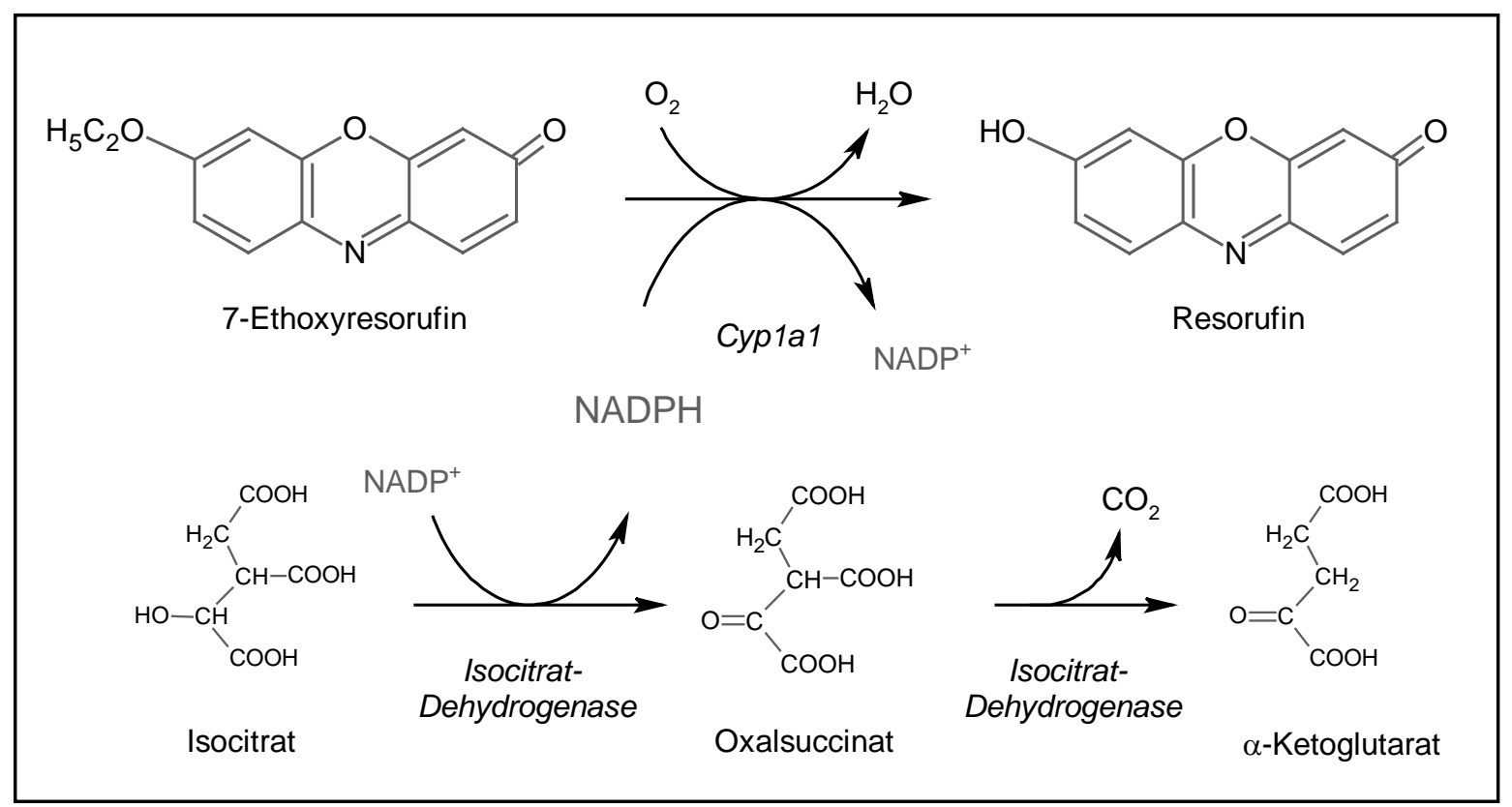

Abbildung 9: Isocitrat-Dehydrogenase/Isocitrat-Redoxsystem für EROD-Assay mit Zellhomogenat

Die Zusammensetzung eines Inkubationsansatzes für eine Probe (1,5 ml-Eppendorf-Cup) lautete wie folgt:

$$
\begin{array}{ll}
25 \mu \mathrm{l} & 1 \mathrm{M} \text { Tris-HCl } \mathrm{pH} 7,4 \\
25 \mu \mathrm{l} & 50 \mathrm{mM} \mathrm{MgCl}_{2} \\
25 \mu \mathrm{l} & 50 \mathrm{mM} \text { Isocitrat }
\end{array}
$$




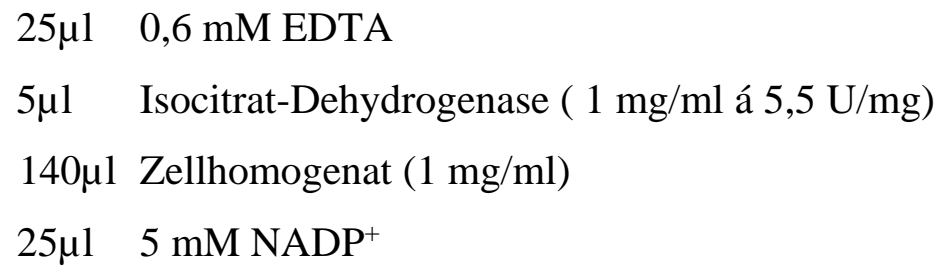

Alle Lösungen wurden mit $\mathrm{H}_{2} \mathrm{O}_{\text {dest }}$ angesetzt und bei $4^{\circ} \mathrm{C}$ und $\mathrm{NADP}^{+}$-Aliquots bei $-20^{\circ} \mathrm{C}$ gelagert. Das Homogenat wurde auf Eis aufgetaut und auf $1 \mathrm{mg} / \mathrm{ml}$ Konzentration mit $\mathrm{H}_{2} \mathrm{O}_{\text {dest }}$ verdünnt. Um Fehler zu minimieren, wurde ein $\mathrm{Mix}$ aus Tris- $\mathrm{HCl}, \mathrm{MgCl}_{2}$, Isocitrat und EDTA hergestellt und vorgelegt, erst dann die Isocitrat-Dehydrogenase, das Zellhomogenat und $\mathrm{NADP}^{+}$einzeln hinzugefügt. Zudem wurde für alle Proben eines Versuchsansatzes die gleiche Homogenatverdünnung verwendet. Als Leerkontrollen wurden bei jedem Versuchsansatz jeweils eine Probe anstatt Homogenat mit $140 \mu \mathrm{l}$ Tris-Succhrose Puffer (im gleichen Verhältnis wie das Homogenat mit $\mathrm{H}_{2} \mathrm{O}_{\text {dest }}$ verdünnt) und eine Probe anstatt $\mathrm{NADP}^{+}$ mit $25 \mu \mathrm{l} \mathrm{H} \mathrm{O}_{\text {dest }}$ mitgeführt.

Die Ansätze wurden bei $37^{\circ} \mathrm{C}$ im Thermomixer (5436, Eppendorf, Hamburg) 2 min vorinkubiert und anschließend jeweils mit 2,7 $\mu$ l der Testsubstanzen in Verdünnungsreihen versetzt. Nach 10 min Inkubation bei $37^{\circ} \mathrm{C}$ im Thermomixer wurden pro Probe $5 \mu \mathrm{l} 100 \mu \mathrm{M}$ Dicumarol und $5 \mu \mathrm{l} 75 \mu \mathrm{M}$ Ethoxyresorufin, jeweils in PBS verdünnt, zum Starten der Reaktion hinzugefügt. Diese wurde nach 60 min bei $37^{\circ} \mathrm{C}$ im Thermomixer und unter Lichtausschluss (Aluminiumfolie) mit 500 l 96\%igem EtOH gestoppt. Um das denaturierte Protein zu sedimentieren, wurden die Proben mit $9490 \mathrm{Upm}$ (8000g) 5 min bei $4^{\circ} \mathrm{C}$ zentrifugiert (Centrifuge 4515R, Eppendorf, Hamburg). Je $200 \mu \mathrm{l}$ aus dem Überstand wurden in schwarze 96-well-Fluoreszenzplatten überführt und bei $530 \mathrm{~nm}$ Anregung und $590 \mathrm{~nm}$ Emission (s. 2.5.2) gemessen. Anhand einer Standardkurve aus 6 Standardpunkten von einer 312,5 nM Resorufinlösung in 70\% Ethanol in 1:2 Verdünnungen in PBS wurden die Produktkonzentrationen bestimmt.

\section{$2.6 \quad$ Tierversuch}

Für den durchgeführten Tierversuch lag eine Genehmigung des Landesamts für Verbraucherschutz und Lebensmittelsicherheit mit dem Aktenzeichen 33.11.42502-04-0130.05 vor. 


\subsubsection{Versuchstiere und Haltungsbedingungen}

Für den Tierversuch wurden 3 Monate alte männliche Mäuse (C57 Bl/6N) aus eigener Zucht mit einem durchschnittlichen Körpergewicht von 28 g verwendet. Die Tiere wurden in Makrolon ${ }^{\mathrm{TM}}$-Käfigen (Typ IV) bei $23^{\circ} \mathrm{C}$ und einer relativen Luftfeuchtigkeit von $55 \%$ in Gruppen von 7 Tieren pro Käfig gehalten. Der Haltungsraum war täglich 12 h/d beleuchtet und den Tieren stand sojafreies Futter (Spezialanfertigung, Ssniff, Soest) sowie Trinkwasser ad libitum zur Verfügung.

\subsubsection{Subakute Applikation von Testsubstanzen}

Die folgenden Testsubstanzen wurden für die angegebenen Gruppen in reinem Olivenöl suspendiert:
1. Vehikel Olivenöl (EuAB/DAB)
2. $\beta$-Estradiol 17-Valerat (E2V) $600 \mu \mathrm{g} / \mathrm{kg}$ Körpergewicht (Kg)
3. $4 \mathrm{MBC} \quad 600 \mathrm{mg} / \mathrm{kg} \mathrm{Kg}$
4. 3-Methylcholanthren (3MC) $40 \mathrm{mg} / \mathrm{kg} \mathrm{Kg}$
5. E2V $600 \mu \mathrm{g} / \mathrm{kg}$ plus 3MC $40 \mathrm{mg} / \mathrm{kg} \mathrm{Kg}$
6. $4 \mathrm{MBC} 600 \mathrm{mg} / \mathrm{kg}$ plus $3 \mathrm{MC} 40 \mathrm{mg} / \mathrm{kg} \mathrm{Kg}$

Zur Berechnung des Ansatzprotokolls der Testsubstanzen wurden die Tiere kurz vor Versuchsbeginn gewogen und das mittlere Körpergewicht berechnet. Zur Homogenisierung wurden die 3MC-Kristalle in Suspension mit einem Ultra Turrax (TP18/10, Janke \& Kunkel, Staufen) zerkleinert sowie alle Suspensionen vor der Applikation 10 min gerührt. Für die Behandlungsgruppen mit Estradiol wurde ein Depotpräparat in Form des $\beta$-Estradiol 17Valerats verwendet.

Die Mäuse wurden zu Gruppen von je 10 Tieren zusammengefasst. Die Applikation erfolgte an 3 Tagen morgens in $24 \mathrm{~h}$ Intervallen. Dabei wurde jeweils 0,1 ml der suspendierten Testsubstanzen, beziehungsweise des reinen Olivenöls, über eine Magensonde verabreicht.

\subsubsection{Sektion}

Unter einer tiefen $\mathrm{CO}_{2}$-Narkose wurden die Tiere $4 \mathrm{~h}$ nach der letzten Substanzapplikation durch Dekapitation getötet. Dabei wurde das Blut aufgefangen und die Leber herauspräpa- 
riert. Die Leber wurde sofort in flüssigem Stickstoff tiefgefroren und nachfolgend bei $-70^{\circ} \mathrm{C}$ gelagert. Das Blut wurde auf Eis gelagert, anschließend abzentrifugiert (2000 g für 30 Minuten) und das Serum bei $-20^{\circ} \mathrm{C}$ bis zur weiteren Verwendung eingefroren.

\subsubsection{Messparameter}

Während des Versuches wurden die Tiere täglich auf Anzeichen einer toxischen Wirkung der Testsubstanzen hin untersucht und das Körpergewicht erneut am Tötungstag gemessen. Folgende Parameter wurden bestimmt:

- Leber: Gewicht, mRNA-Expression von CYP1A1, ERa, AhR und ARNT

- Serum: Serumkonzentration von Estradiol

\subsubsection{Serumanalyse durch Radioimmunoassay}

Im Radioimmunoassay (Yalow und Berson 1959) wird das im Serum befindliche Hormon sowie ein radioaktiv markiertes Hormon (Tracer) bekannter Aktivität mit einem primären Antikörper zur Reaktion gebracht. Dabei konkurrieren das markierte und das zu messenden Substrat um die Bindungsstelle des Antikörpers. Der ungebundene Tracer wird durch eine sich anschließende Fällung der Primärantikörperkomplexe entfernt. Die in der Probe erhaltene Radioaktivität ist umgekehrt proportional zu dem Hormongehalt der entsprechenden Probe, dessen Konzentration über eine Standardkurve bestimmt werden kann.

Für die Messung der Serumkonzentration wurde ein kommerziell erhältliches Kit nach Herstellerangaben verwendet:

Estradiol: $\quad$ Human Estradiol RIA-Kit, 39100, DSL, Sinsheim

\subsection{Molekularbiologische Arbeiten}

\subsubsection{Arbeiten mit Nukleinsäuren}

Um Kontaminationen der in Lösung befindlichen RNA mit Ribonukleasen (RNasen) zu vermeiden, wurden alle Arbeiten mit Ethanol-gewaschenen Handschuhen durchgeführt. Lösungen wurden entweder als sterile und RNase-freie Stammlösungen erstanden oder mit Velcorin behandeltem Wasser $\left(\mathrm{H}_{2} \mathrm{O}_{\text {velc }}\right)$ angesetzt. Alle Plastikwaren wurden für 20 min bei $120^{\circ} \mathrm{C}$ autoklaviert und Glaswaren für 12 Stunden bei $240^{\circ} \mathrm{C}$ sterilisiert. Proben wurden auf Eis aufgetaut und jedes weitere Einfrieren und wiederholtes Auftauen vermieden. 


\subsubsection{RNA-Extraktion}

\subsubsection{Aus Zellkultur}

Zum Extrahieren der RNA aus H4IIE-Zellen wurden 100000 Zellen in 2 ml PKM pro well einer 24-well-Platte ausplattiert und $48 \mathrm{~h}$ bei $37^{\circ} \mathrm{C}, 5 \% \quad \mathrm{CO}_{2}$ und einer relativen Luftfeuchtigkeit von 96\% inkubiert. Zur Belastung wurde das Medium durch frisches ersetzt, dem die in DMSO gelösten Testsubstanzen zugeben wurden. Zusätzlich enthielt jeder Assay eine Lösungsmittelkontrolle von DMSO in der niedrigsten Verdünnung sowie eine Positivkontrolle mit 3-Methylcholanthrene (3MC) $1 * 10^{-6} \mathrm{M}$. Nach 48 h Inkubation wurde das Medium abgesaugt und der Zellrasen einmal mit PBS gewaschen.

Zur Isolation der Gesamt-RNA wurde der RNeasy ${ }^{\circledR}$ Minikit (Qiagen, Hilden) benutzt. Dafür wurden jeweils $350 \mu \mathrm{l}$ Lysispuffer auf die Zellen pro well gegeben und die 24-well-Platte anschließend für $10 \mathrm{sec}$ in ein Ultraschallbad (Bransonic 32 Sonicator Bath, Branson Instruments, Danbury, CT, USA) gestellt. Zu dem Homogenat wurde $350 \mu \mathrm{l}$ 70\% Ethanol pipettiert und die nun $700 \mu$ l Suspension nach guter Durchmischung mit der Pipettenspitze auf die Extraktionssäule des RNeasy Kits gegeben. Die Aufreinigung wurde den Herstellerangaben entsprechend durchgeführt und die gereinigte RNA mit $50 \mu \mathrm{l} \mathrm{H}_{2} \mathrm{O}_{\text {velc }}$ eluiert.

\subsubsection{Aus Mäuselebergewebe}

Die Mäuselebern wurden bis zur Probenaufbereitung bei $-70^{\circ} \mathrm{C}$ gelagert. Bei dieser wurden Stücke des gefrorenen Organs in einem stickstoffgekühlten Teflongefäß in einem GewebeHomogenisator (Micro-dismembranator ${ }^{\mathrm{TM}}$, Braun, Melsungen) für 20 sec bei $2500 \mathrm{UpM}$ zerkleinert. Ca. $50 \mathrm{mg}$ des Gewebepulvers wurden in $600 \mu \mathrm{l}$ Lysispuffer aufgenommen und 15 sec im Ultraschallbad (Sonifier B12, Branson Instruments, Danbury, CT, USA) homogenisiert. Das Homogenat wurde anschließend auf QIAShredder ${ }^{\mathrm{TM}}$-Säulen (Quiagen, Hilden) gegeben, um es von groben Gewebestückchen zu befreien. Das Eluat wurde anschließend mit $500 \mu \mathrm{l}$ 70\% EtOH versetzt und auf die Extraktionssäule des RNeasy® Kits (Qiagen) gegeben. Die Gesamt-RNA wurde nach Herstellerangaben aufgereinigt und mit $50 \mu \mathrm{l} \mathrm{H} \mathrm{O}_{2}$ velc eluiert. 


\subsubsection{Konzentrationsbestimmung der RNA}

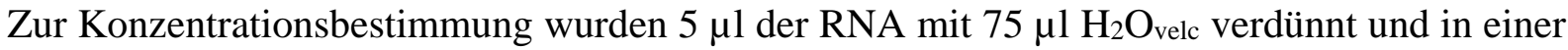
Quarzküvette (Suprasil ${ }^{\circledR}$, Hellma, Müllheim) in einem Photometer (Biophotometer, Eppendorf, Hamburg) die Extinktion bei $260 \mathrm{~nm}$ und 280 nm gegen den Leerwert gemessen. Eine optische Dichte (OD) von 1 bei $260 \mathrm{~nm}$ entspricht dabei einer RNA-Konzentration von ca. $40 \mu \mathrm{g} / \mathrm{ml}$. Die Reinheit der RNA läßt sich aus dem Quotienten von $\mathrm{OD}_{260 \mathrm{~nm}} \mathrm{zu} \mathrm{OD}_{280 \mathrm{~nm}}$ bestimmen, der bei 1,8 bis 2 die Annahme der Reinheit erlaubt (Sambrook 1989). Bei niedrigeren Werten kann dies aufgrund der Absorptionseigenschaften aromatischer Aminosäuren bei $280 \mathrm{~nm}$ ein Hinweis auf eine Verunreinigung der Lösung durch Proteine sein.

\subsubsection{Reverse Transskription (RT)}

Durch die reverse Transkription wird die gewonnene RNA in eine komplementäre DNA (cDNA) umgeschrieben und so eine Vorlage (Template) für die nachfolgende realtime-PCR (RT-PCR) erstellt. Dazu wurde ein Kit einer murinen retroviralen reversen Transskriptase ohne RNase-Aktivität eingesetzt. Die RNA-Lösungen wurden auf 90 ng/ $\mu \mathrm{l}$ (H4IIE-Zell-RNA) bzw. $20 \mathrm{ng} / \mu \mathrm{l}$ (Mäuseleber-RNA) mit $\mathrm{H}_{2} \mathrm{O}_{\text {velc }}$ eingestellt, danach pro Ansatz $10 \mu \mathrm{l}$ RNALösung mit $3 \mu \mathrm{H}_{2} \mathrm{O}_{\text {velc }}$ und $1 \mu \mathrm{l}$ Random-Primer (Invitrogen, Karlsruhe, 1:30 verdünnt in $\mathrm{H}_{2} \mathrm{O}_{\text {velc }}$ ) versetzt und $10 \mathrm{~min}$ bei $70^{\circ} \mathrm{C}$ inkubiert, um Sekundärstrukturen zu denaturieren. Anschließend wurde zu jedem Ansatz ein Mastermix aus folgenden Bestandteilen pipettiert: Mastermix:

$$
\begin{aligned}
& 4 \mu \text { l RT-Kit-Puffer } \\
& 1 \mu \text { l Reverse Transkriptase (RT) } \\
& 1 \mu \mathrm{l} 10 \text { mM dNTP-Mix } \\
& 0,1 \mu \mathrm{l} \text { RNasin }
\end{aligned}
$$

Bei einer Inkubation von $10 \mathrm{~min}$ bei $22^{\circ} \mathrm{C}$ erfolgte die Anlagerung der Primer. Darauf folgend wurden die Gegenstränge während der sich anschließenden $50 \mathrm{~min}$ bei $42^{\circ} \mathrm{C}$ synthetisiert. Nach einem Enzymdenaturierungsschritt bei $95^{\circ} \mathrm{C}$ für 10 min wurden die Ansätze kurz abzentrifugiert und die gewonnene cDNA bei $-20^{\circ} \mathrm{C}$ bis zur weiteren Verwendung eingefroren. 


\subsubsection{Real-Time Detection PCR (RTD-PCR)}

\subsubsection{Methode}

Anders als bei der klassischen PCR (Mullis und Faloona 1987) mit nachfolgender Endpunktanalyse ist bei der RT-PCR eine gleichzeitige Amplifizierung und Quantifizierung der Konzentration der Ziel-DNA mittels Fluoreszenzmessung möglich (Higuchi et al. 1992). Bei dem Taqman ${ }^{\mathrm{TM}}$-Prinzip (Livak et al. 1995; Heid CA et al. 1996) wird die zusätzlich zur Polymeraseaktivität bestehende 5'-, 3'- Exonucleaseaktivität der Taq-Polymerase zur Spaltung einer genspezifischen Sonde (Taqman ${ }^{\mathrm{TM}}$-Probe) benutzt (Holland et al. 1991). Diese liegt zwischen den beiden spezifischen Oligonucleotid-Primern auf der Zielsequenz und trägt am 5'-Ende einen Reporterfluoreszenzfarbstoff (6-Carboxy-fluorescein, FAM) und am 3'Ende einen Quencherfarbstoff (6-Carboxy-tetramethyl-rhodamin, TAMRA). Wird der Reporterfluoreszenzstoff mit Licht der Wellenlänge 488 nm angeregt, strahlt dieser Licht mit der Wellenlänge $518 \mathrm{~nm}$ ab, das bei intakter Sonde vom räumlich benachbarten Quencherfarbstoff aufgenommen wird (Fluoreszenz-Resonanz-Energie-Transfer, FRET). Bei der PCR wird im Verlauf der Neustrangsynthese die an die DNA gebundene Sonde durch die Taq-Polymerase abgebaut. Aufgrund der nun räumlichen Trennung der beiden Farbstoffmoleküle wird der Energietransfer unterbrochen und die Reporterfluoreszenzemission detektierbar. Die Messung des Fluoreszenzsignals findet am Ende der Elongation nach jedem Zyklus statt. Die Signalstärke ist dabei proportional zur Konzentration des DNA-Templates.

Die PCR wird durch die Berechnung des Fluoreszenzschwellenwertes (threshold cycle, СтWert) quantifiziert. Dieser beschreibt denjenigen Zyklus der PCR, an dem die Reporterfluoreszenzemission erstmalig signifikant über die Hintergrund-Fluoreszenz ansteigt. Durch seine Lage am Anfang der exponentiellen Phase der Amplifizierung steht der $\mathrm{C}_{\mathrm{T}}$-Wert in einer linearen, umgekehrt proportionalen Beziehung zum Logarithmus der Templateausgangsmenge. Anhand einer Standardkurve, erstellt aus einer parallel amplifizierten Verdünnungsreihe einer bekannten Templatemenge, können so bestimmten CT-Werten Templateausgangsmengen zugeordnet werden.

\subsubsection{Durchführung}

Für die Messung der Genexpression von AhR, ARNT und CYP1A1 in den H4IIE-Zellen sowie CYP1A1 im Tierversuch wurden bereits im Labor vorhandene und validierte Systeme 
verwendet. Alle Primer und Sonden (Sequenzen im Anhang, siehe Tabelle 7.1) wurden von Eurogentec (Seraing, Belgien) bezogen.

Reaktionsansatz: $\quad 12,5 \mu 1$ Taqman ${ }^{\mathrm{TM}}$-PCR-Mastermix mit 3,5 mM $\mathrm{MgCl}_{2}$

$$
\begin{aligned}
& \text { 0,25 U Uracil-N-glycosylase } \\
& 0,75 \mu \mathrm{l} 300 \mathrm{nM} \text { jedes Primers } \\
& 0,56 \mu \mathrm{l} 225 \mathrm{nM} \text { Sonde } \\
& 2-4 \mu \mathrm{l} \mathrm{cDNA} \\
& \text { ad } 25 \mu \mathrm{l} \mathrm{H}_{2} \mathrm{O}_{\text {velc }}
\end{aligned}
$$

Für die Messung der Genexpression von AhR, ARNT und ER $\alpha$ im Tierversuch wurden folgende murine Kits verwendet:

- AhR: TaqMan ${ }^{\mathrm{TM}}$ Gene Expression Assays, ID Mm00478932_m1

(Applied Biosystems, Darmstadt)

- ARNT: TaqMan ${ }^{\mathrm{TM}}$ Gene Expression Assays, ID Mm00507836_m1

(Applied Biosystems, Darmstadt)

Reaktionsansatz (nach Herstellerangaben):

12,5 $\mu$ l Taqman ${ }^{\mathrm{TM}}$-PCR-Mastermix mit 3,5 $\mathrm{mM} \mathrm{MgCl}_{2}$

0,25 U Uracil-N-glycosylase

1,25 $\mu \mathrm{l} 20 \mathrm{x}$ Assay Mix

2-4 $\mu \mathrm{l} \mathrm{cDNA}$

ad $25 \mu \mathrm{l} \mathrm{H}_{2} \mathrm{O}_{\text {velc }}$

- ER-a: Quanti Tect Primer Assay, ID Mm_Esr1_1_SG

Die Ansätze für jeweils ein Zielgen wurden in 96-well-Platten pipettiert und diese mit optischen Deckelketten verschlossen. Bei jedem Ansatz wurde dabei eine Standardkurve aus 6 bis 8 Standardpunkten in Doppelbestimmung sowie 6 Kontrollen ohne cDNA mitgeführt, um Kontaminationen auszuschließen.

Die RTD-PCR wurde in einem ABI PRISM ${ }^{\mathrm{TM}} 7700$ Sequence detector (Perkin Elmer, Rodgau-Jügesheim) über 40 Zyklen mit folgendem Programm durchgeführt:

PCR Programm:

1. $94^{\circ} \mathrm{C}-180 \mathrm{~s}$ 
2. $94^{\circ} \mathrm{C}-30 \mathrm{~s}$

3. $60^{\circ} \mathrm{C}-90 \mathrm{~s}$

Schritte 2-3 39-mal wiederholt

4. $\quad 72^{\circ} \mathrm{C}-10 \mathrm{~min}$

Die Daten wurden mit dem Programm Sequence Detection Systems (Ver. 1.9.1) von Applied Biosystems (Darmstadt) ausgewertet.

\subsection{Statistische Auswertung}

Zunächst wurden die Rohdaten anhand des Grubbs-Tests (Burke S 2001) auf Ausreißer hin untersucht. Dabei wurde folgende Formel verwendet:

$$
G=\frac{\left|\bar{x}-x_{i}\right|}{s}
$$

wobei $\bar{x}$ den Mittelwert der Gruppe, $x_{i}$ den Einzelwert und $s$ die Standardabweichung darstellen. Wenn der erhaltene Wert dabei größer war als der kritische Wert für das 95\% Konfidenzintervall, wurde der entsprechende Messwert als Ausreißer betrachtet und entfernt. Anschließend wurden die Messwerte mit dem Programm Prism ${ }^{\circledR}$ (Ver.4, GraphPad, San Diego CA, USA) ausgewertet. Bei zwei Gruppen wurde der student's t-Test, bei drei oder mehr Gruppen eine ANOVA (One-way analysis of variance) sowie ein Dunnett's Multiple Comparison Post-Test verwendet. Ein p-Wert von < 0,05 wurde als signifikant betrachtet (in den Abbildungen mit * oder \# markiert).

Die Ergebnisse sind jeweils als Mittelwert sowie als Standardfehler des Mittelwertes (Mean \pm SEM) aufgetragen. Soweit in den Graphen nicht abweichende Einheiten angegeben sind, wurden die Messwerte der einzelnen Gruppen auf die Mittelwerte der Kontrollgruppe (=100\%) prozentrelativiert (\% rel). 


\section{Ergebnisse}

\section{1 $\quad$ EROD-Assay mit Zellkultur}

\subsubsection{EROD-Assay mit 3MC}

In diesem EROD-Assay wurde der Einfluss von Estradiol, 4MBC und anderen Substanzen auf die EROD-Aktivität der H4IIE-Zellkultur untersucht. Dabei wurden die Möglichkeiten der Induktion sowie der Hemmung der Induktion berücksichtigt. Die maximale Induktion der EROD-Aktivität durch die Positivkontrolle 3MC (Abbildung 10) wurde bei einer Konzentration von $1 * 10^{-6} \mathrm{M}$ erreicht, welches eine 120 fache Steigerung gegenüber der Kontrollgruppe darstellt. Auch niedrigere Konzentrationen von $1 * 10^{-7} \mathrm{M}$ bis $5 * 10^{-7} \mathrm{M}$ wiesen eine signifikante dosisabhängige Steigerung der EROD-Aktivität auf. Höhere Konzentrationen über $1 * 10^{-6} \mathrm{M}$ erhöhten dagegen die EROD-Aktivität nicht.

\section{E R O D -A s say}

\section{M C}

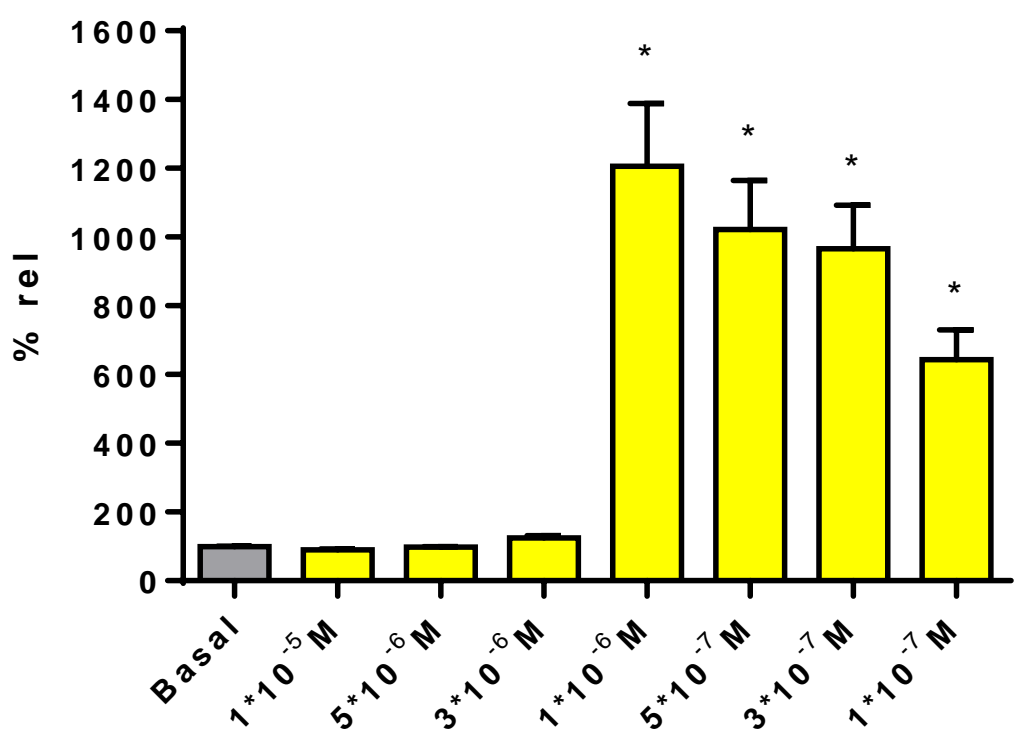

Abbildung 10: Induktion der EROD-Aktivität in der Zellkultur durch 3MC. Die Werte (n = 24, 4 Experimente mit 6 Replikaten) wurden auf die Kontrollgruppe (Basal = Lösungsmittelkontrolle mit DMSO) relativiert. * = signifikant gegen die Gruppe „Basal“. In dieser und allen folgenden Graphiken sind Mittelwerte sowie die Standardfehler des Mittelwertes (SEM) abgebildet. Als signifikant wurde ein p-Wert < 0,05 betrachtet. 


\subsubsection{EROD-Assay mit Estradiol}

Bei der Testung auf eine mögliche Induktion der EROD-Aktivität durch Estradiol (Abbildung 11) konnte bei keiner der getesteten Konzentrationen ein signifikanter Unterschied zur Kontrolle festgestellt werden. Im Hinblick auf eine potentielle Hemmung der Induktion zeigte die Koinkubation von Estradiol und 3MC im EROD-Assay (Abbildung 12) eine deutlich signifikante Reduktion der EROD-Aktivität ab einer Konzentration von 2,5* $10^{-6} \mathrm{M}$. Die maximale Hemmung der Induktion durch Estradiol um 62\% wurde bei einer Konzentration von $5 * 10^{-5} \mathrm{M}$ erreicht.
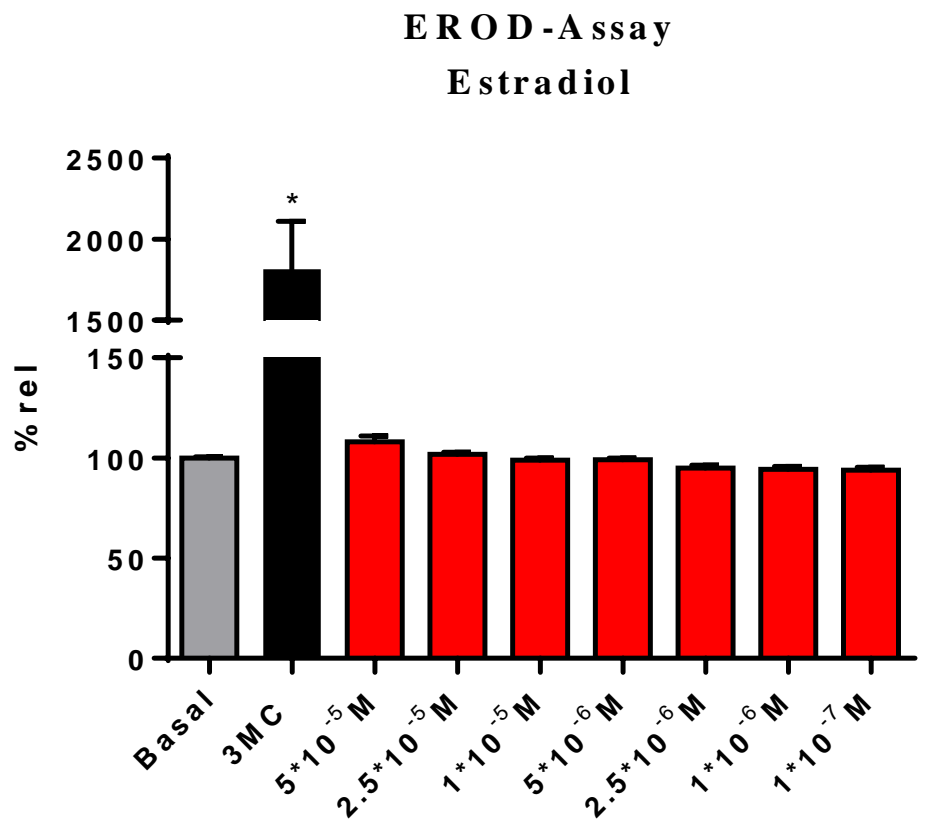

Abbildung 11: EROD-Assay in der Zellkultur mit Estradiol. Die Werte $(n=18,3$ Experimente mit 6 Replikaten) wurden auf die Kontrollgruppe (Basal) relativiert. * = signifikant gegen die Gruppe „Basal“. 
E R O D -Assay

Koinkubation von Estradiol und 3 M C

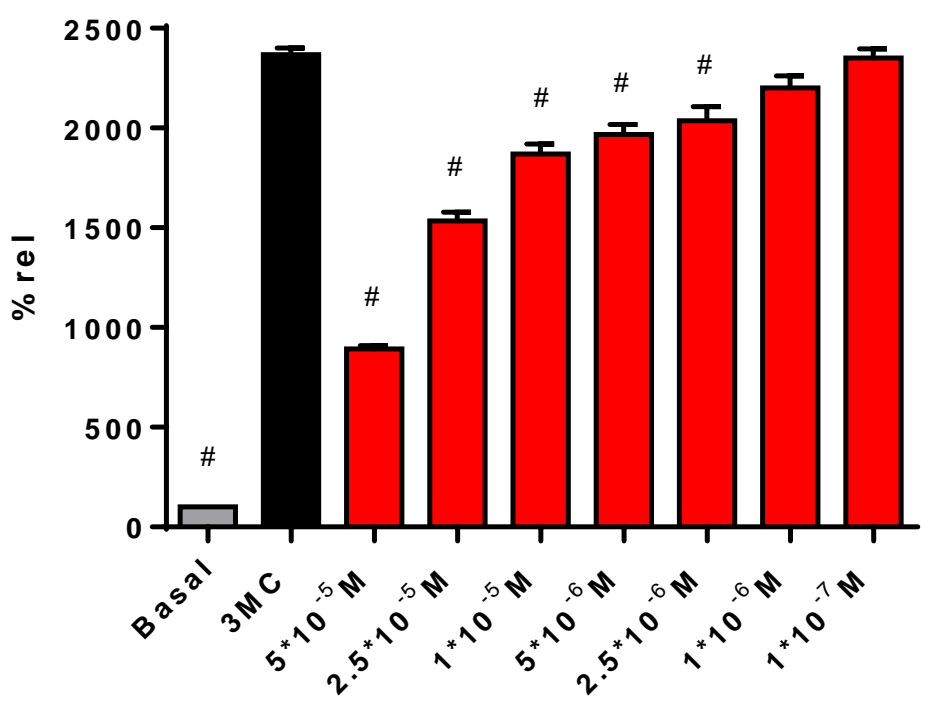

Abbildung 12: EROD-Assay in der Zellkultur bei Koinkubation von Estradiol mit 3MC $\left(1 * 10^{-6} \mathrm{M}\right)$. Die Werte $(\mathrm{n}=18,3$ Experimente mit 6 Replikaten) wurden auf die Kontrollgruppe (Basal) relativiert. \# = signifikant gegen die Gruppe „3MC $\left(1 * 10^{-6} \mathrm{M}\right) “$.

\subsubsection{EROD-Assay mit 4MBC}

Im EROD-Assay mit 4MBC als möglichen Induktor der EROD-Aktivität (Abbildung 13) zeigte sich bei allen getesteten Konzentrationen keine signifikante Steigerung der ERODAktivität gegenüber der Kontrolle. Bei der Koinkubation von 4MBC mit dem Induktor 3MC ließ sich eine deutlich signifikante Hemmung der Induktion ab einer Konzentration von 2,5*10-5 M durch 4MBC feststellen. Die maximale Reduktion der EROD-Aktivität bei einer Konzentration von $5 * 10^{-5} \mathrm{M}$ lag bei ca. $57 \%$. 


\section{E R O D - A s s a y}

4M B C

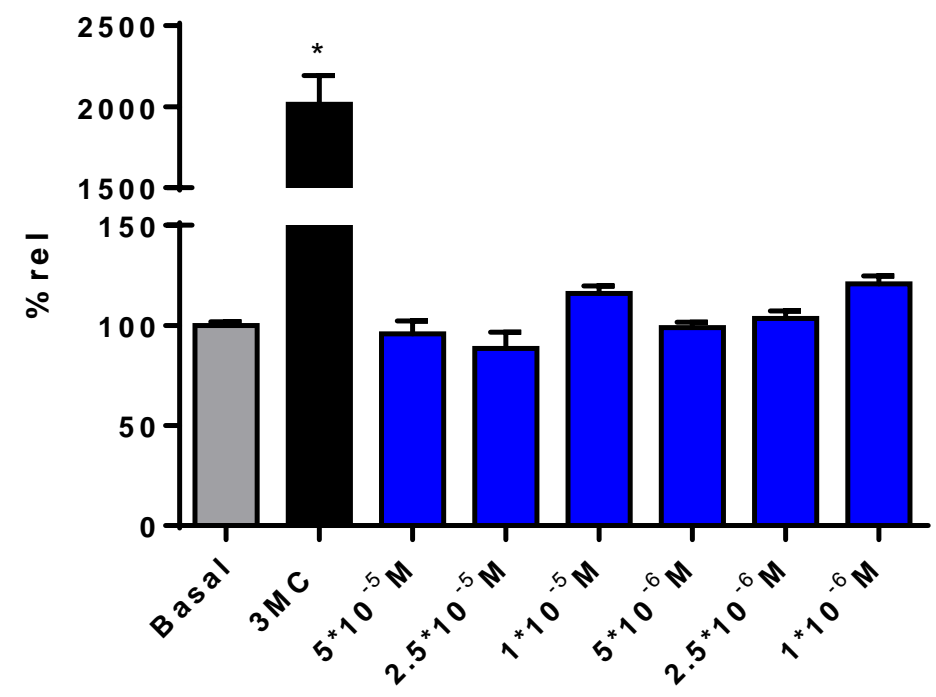

E R O D - A ssay

Koinkubation von 4M B C und 3 M C

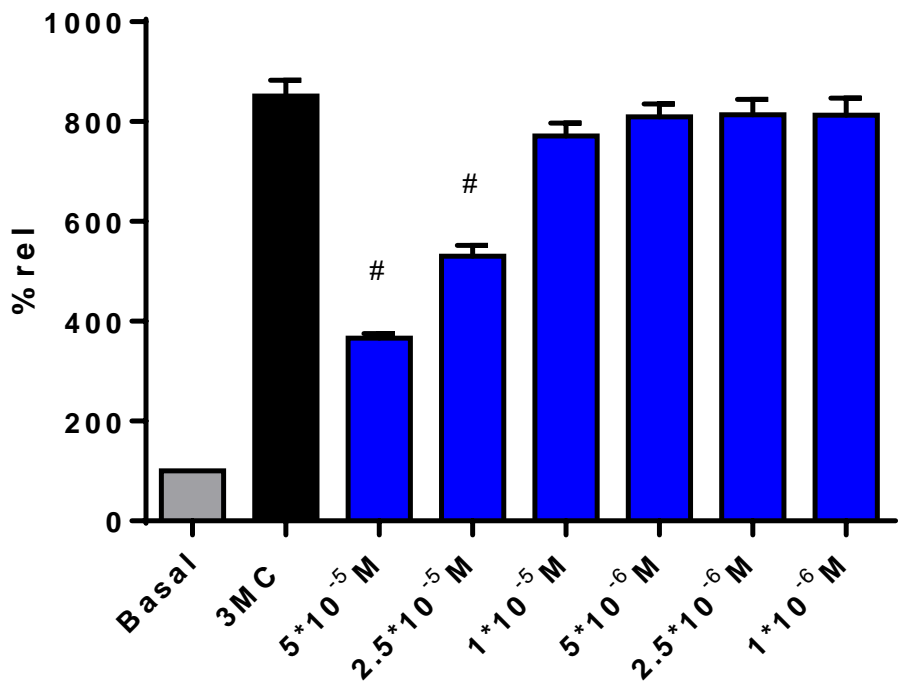

Abbildung 13: EROD-Assay in der Zellkultur mit 4MBC und in Koinkubation mit 3MC. Die Werte ( $\mathrm{n}=18,3$ Experimente mit 6 Replikaten) wurden auf die Kontrollgruppe (Basal) relativiert. Oben ist die Inkubation mit 4MBC in den angegebenen Konzentrationen dargestellt. * = signifikant gegen die Gruppe „Basal“. Unten ist die Koinkubation mit 3MC $\left(1 * 10^{-6} \mathrm{M}\right)$ dargestellt. \# = signifikant gegen die Gruppe „3MC $\left(1 * 10^{-6} \mathrm{M}\right)^{\text {“. }}$. 


\subsubsection{EROD-Assay mit Estradiol und ICI}

Bei beiden Testsubstanzen, Estradiol und 4MBC, wurde versucht, die hemmende Wirkung auf die Induktion der EROD-Aktivität mit 3MC durch den Estrogenrezeptor-Antagonisten ICI 182,780 $\left(1 * 10^{-6} \mathrm{M}\right)$ zu blockieren. ICI 182,780 hatte dabei selbst, ebenso wenig wie Estradiol und 4MBC, keinen induzierenden Einfluss auf die EROD-Aktivität.

Bei der Koinkubation von Estradiol und 3MC (Abbildung 14) wurde erneut ein hemmender Effekt von ca. 68\% auf die Induktion gemessen, die Zugabe von ICI 182,780 hatte hierauf keinen Einfluss. Beide Gruppen unterschieden sich in einem student's t-test nicht signifikant voneinander.

\section{EROD-Assay}

Koinkubation von Estradiol $m$ it $3 M C$ und ICI

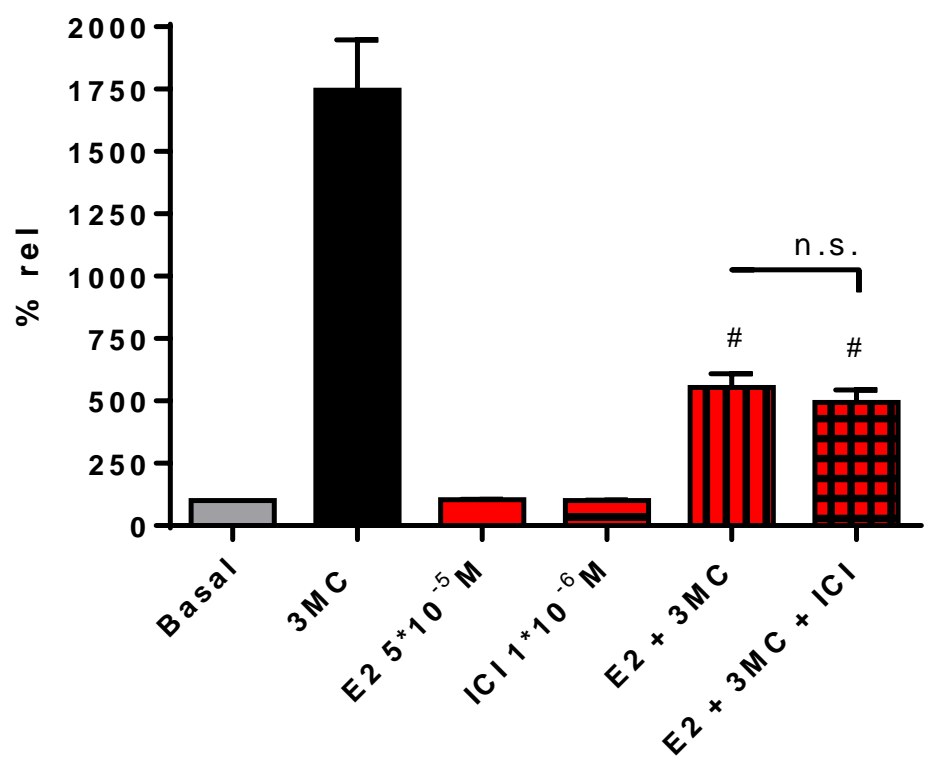

Abbildung 14: EROD-Assay in der Zellkultur mit ICI 182,780 und in Koinkubation mit 3MC und Estradiol. Die Werte $(\mathrm{n}=18,3$ Experimente mit 6 Replikaten) wurden auf die Kontrollgruppe (Basal) relativiert. \# = signifikant gegen die Gruppe „3MC $\left(1 * 10^{-6} \mathrm{M}\right)^{“}$, n.s.= nicht signifikant. 


\subsubsection{EROD-Assay mit 4MBC und ICI}

Ebenso zeigte sich bei der Koinkubation von 4MBC und 3MC (Abbildung 15) erneut eine signifikante hemmende Wirkung von 4MBC auf die EROD-Aktivität von ca. 46\%. Bei dem Versuch, durch die Zugabe von ICI 182,780 die Hemmung zu blockieren, konnte kein Effekt festgestellt werden. Ein student's t-test wies keinen signifikanten Unterschied zwischen den Gruppen mit und ohne ICI 182,780 auf.

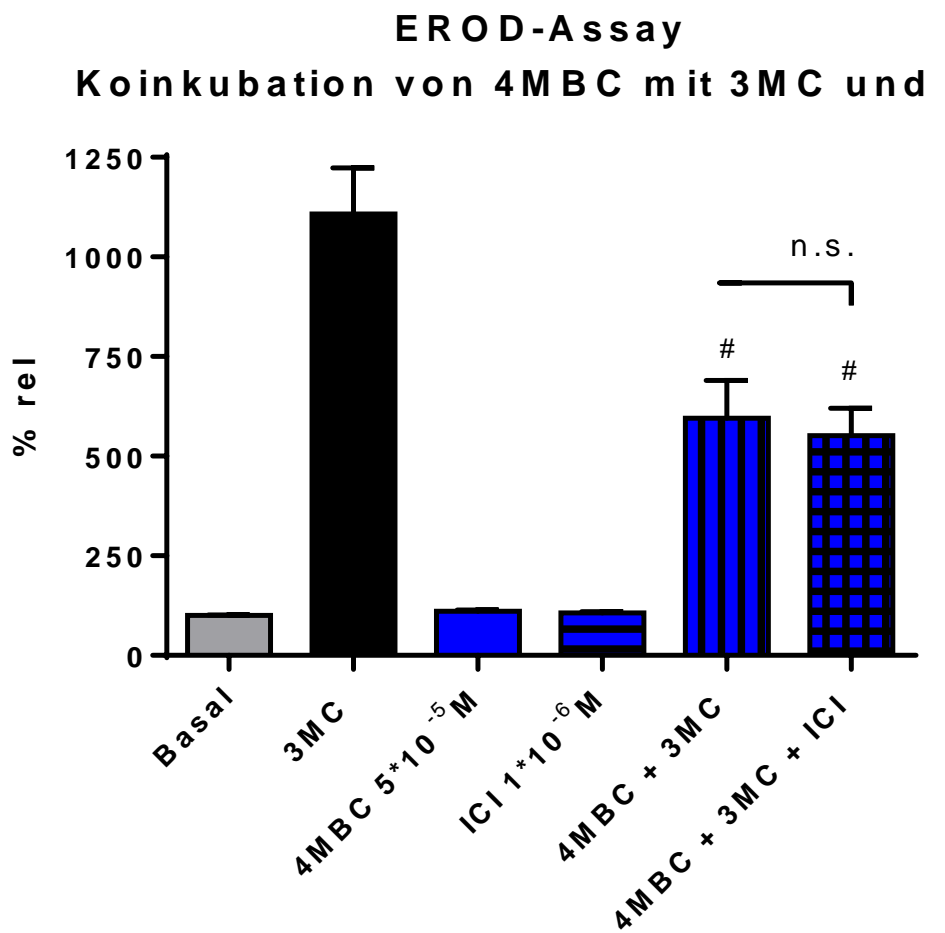

Abbildung 15: EROD-Assay in der Zellkultur mit ICI 182,780 und in Koinkubation mit 3MC und 4MBC. Die Werte ( $n=18$, 3 Experimente mit 6 Replikaten) wurden auf die Kontrollgruppe (Basal) relativiert. \# = signifikant gegen die Gruppee „3MC“ $\left(1 * 10^{-6} \mathrm{M}\right)$, n.s.= nicht signifikant. 


\title{
3.1.6 EROD-Assay mit E2-ähnlichen Substanzen
}

Um Hinweise darauf zu erhalten, inwiefern die molekulare Struktur der Testsubstanz Einfluss auf deren Wirkung im EROD-Assay aufweist, wurden, neben den zuvor untersuchten Substanzen, strukturell ähnliche Substanzen im EROD-Assay der H4IIE-Zellkultur bei einer Konzentration von $5 * 10^{-5} \mathrm{M}$ getestet (Abbildung 16). Als Testsubstanz mit induzierender Wirkung auf die EROD-Aktivität erwies sich neben der Positivkontrolle 3MC lediglich das Phytoestrogen Genistein, bei der eine 2,5fache Induktion gegenüber der Kontrolle gemessen wurde. Die zuvor getesteten Substanzen 17 $\beta$-Estradiol, 4MBC und ICI 182,780 $\left(1 * 10^{-6} \mathrm{M}\right)$ zeigten erneut keine Stimulation der EROD-Aktivität. Ebenso hatten das Stereoisomer $17 \alpha$-Estradiol, das Estrogen Estron sowie das estrogene Stoffwechselprodukt Estriol in der gemessenen Konzentration keinen induzierenden Effekt. Auch bei der Inkubation mit Testosteron konnte keine Steigerung der EROD-Aktivität gegenüber der Kontrolle festgestellt werden.

\author{
EROD-Assay \\ E2 ähnliche Substanzen
}

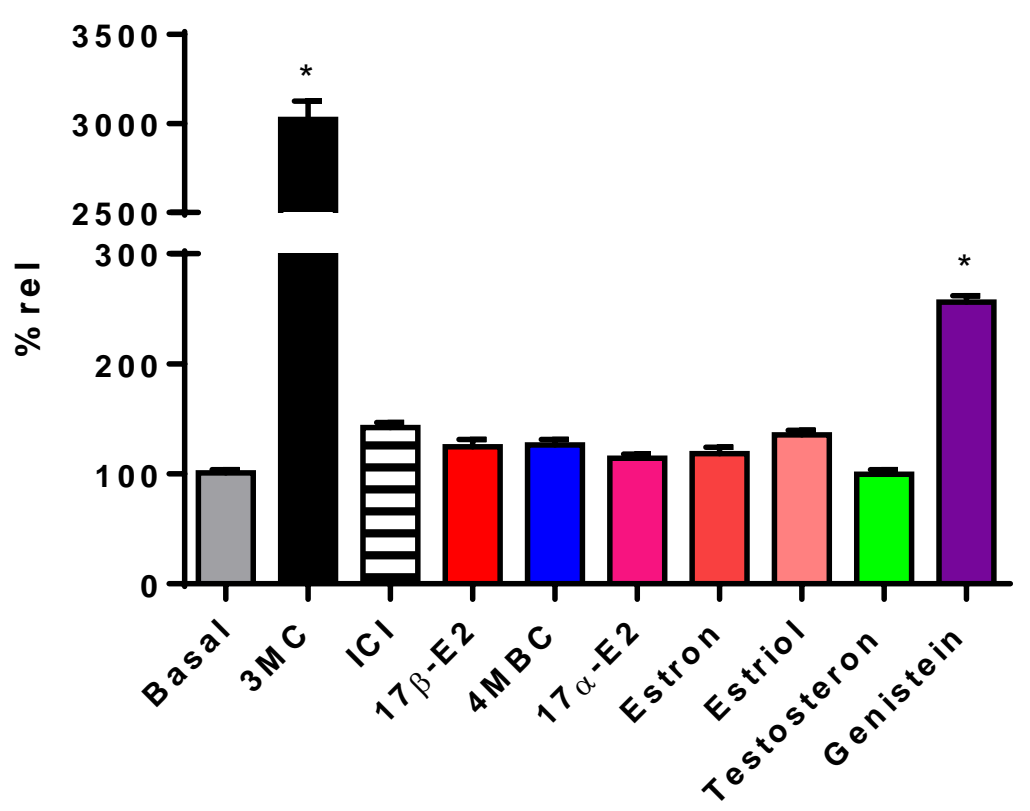

Abbildung 16: Induktion der EROD-Aktivität in der Zellkultur durch Estradiol ähnliche Substanzen. Die Werte ( $\mathrm{n}=18$, 3 Experimente mit 6 Replikaten) wurden auf die Kontrollgruppe (Basal) relativiert. * = signifikant gegen die Gruppe „Basal“. 


\title{
3.1.7 EROD-Assay mit E2-ähnlichen Substanzen und 3MC
}

Die Koinkubation mit dem Induktor 3MC wurde zur Untersuchung möglicher inhibitorischer Effekte der Testsubstanzen auf die EROD-Aktivität (Abbildung 17) in der Konzentration $5 * 10^{-5} \mathrm{M}$ durchgeführt. Dabei zeigten neben $17 \beta$-Estradiol und 4MBC auch die strukturell ähnlichen Substanzen 17 $\alpha$-Estradiol, Estron und Estriol eine unterschiedlich ausgeprägte Hemmung der Induktion. Die Reduktion der EROD-Aktivität gegenüber der Positivkontrolle $3 \mathrm{MC}$ betrug bei $17 \beta$-Estradiol ca. $74 \%$, bei $4 \mathrm{MBC}$ ca. $56 \%$, bei $17 \alpha$-Estradiol ca. $36 \%$, bei Estron ca. 56\% und bei Estriol ca. 29\%. Bei Testosteron, Genistein und ICI 182,780 $\left(1^{*} 10^{-6} \mathrm{M}\right)$ war kein signifikanter Einfluss auf die induzierte EROD-Aktivität festzustellen.

\author{
EROD - A s say \\ Koinkubation von
}

E2 ähnlichen Substanzen $m$ it $3 M C$

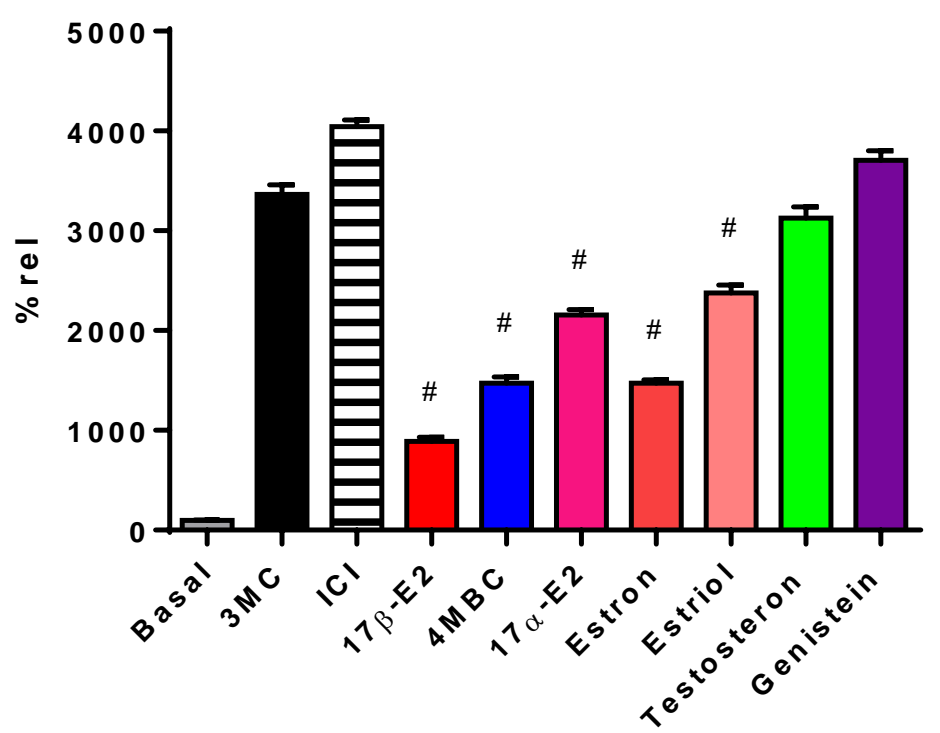

Abbildung 17: EROD-Assay in der Zellkultur mit Estradiol ähnlichen Substanzen in Koinkubation mit 3MC. Die Werte $(n=24,3$ Experimente mit 8 Replikaten) wurden auf die Kontrollgruppe (Basal) relativiert. \# = signifikant gegen die Gruppe „3MC“ $\left(1^{*} 10^{-6} \mathrm{M}\right)$. 


\subsection{Genexpressionsdaten der Zellkultur}

Um eine Induktion durch Ligandenbindung am AhR direkt nachweisen zu können, wurde zusätzlich zur CYP1A1-Aktivität die Genexpression (mRNA nach RT-PCR) des Zielgens CYP1A1 aus der H4IIE-Zellkultur bestimmt, welche über 48h mit 3MC, Estradiol und 4MBC in unterschiedlicher Kombination inkubiert wurde. Eine Aussage über eine mögliche Beeinflussung der nukleären Rezeptoren sollte über die Bestimmung der mRNA von AhR und ARNT getroffen werden können.

\subsubsection{Genexpression von CYP1A1}

Die Expression der CYP1A1-mRNA (Abbildung 18) wurde dabei durch den bekannten Induktor und Positivkontrolle 3MC um das ca. 108fache gegenüber der Kontrolle gesteigert. Im Gegensatz zu den Ergebnissen des EROD-Assays konnte in der Koinkubation mit 3MC auf der Ebene der Genexpression sowohl bei Estradiol als auch bei 4MBC in der Konzentration $5 * 10^{-5} \mathrm{M}$ kein signifikanter Einfluss der beiden Testsubstanzen auf die Induktion durch die Positivkontrolle 3MC festgestellt werden. Bei der alleinigen Inkubation von Estradiol sowie $4 \mathrm{MBC}$ in der Konzentration $5 * 10^{-5} \mathrm{M}$ erwies sich die erhöhte Genexpression von Estradiol um ca. 130\% bzw. von 4MBC um ca. $170 \%$ in einem zusätzlichen ANOVA als nicht signifikant gegenüber der Kontrolle. 
H 4 IIE-G enexpression

CYP 1 A 1

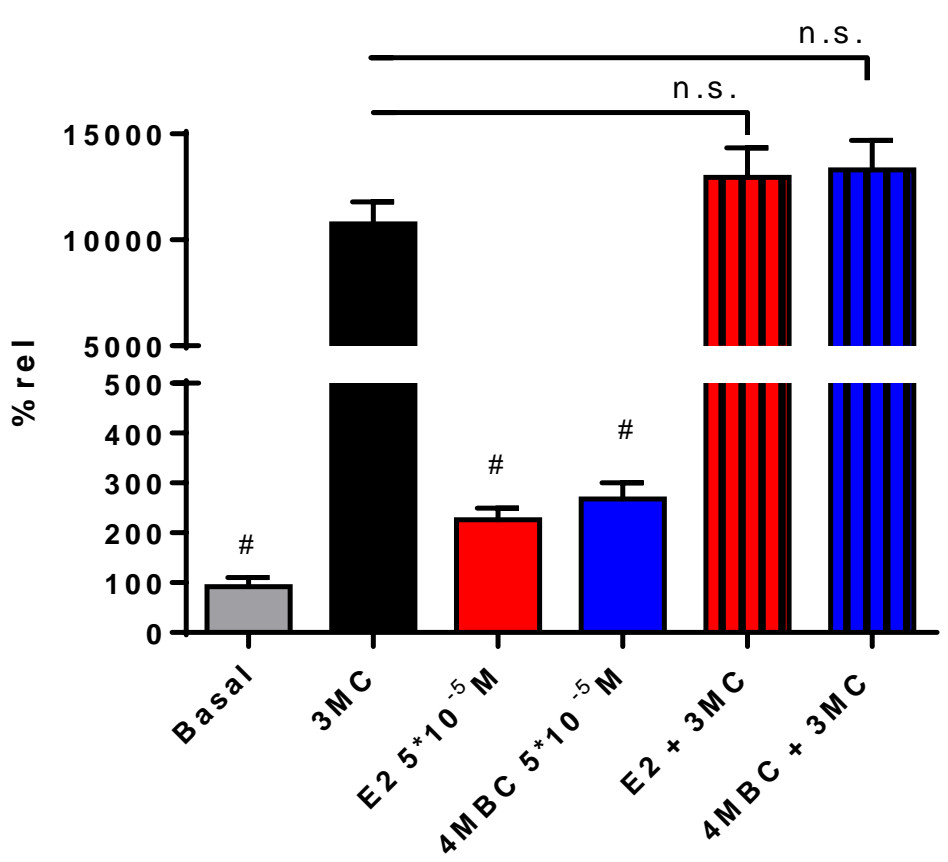

Abbildung 18: CYPA1-Genexpression (RT-PCR) in der H4IIE-Zellkultur nach 48h Inkubation. Die Werte ( $\mathrm{n}=12$, 3 Experimente mit 4 Replikaten) wurden auf die Kontrollgruppe (Basal) relativiert. \# = signifikant gegen die Gruppe „3MC“ $\left(1 * 10^{-6} \mathrm{M}\right)$, n.s.= nicht signifikant.

\subsubsection{Genexpression von AhR}

Die Genexpression des Arylhydrocarbon-Rezeptors (AhR) (Abbildung 19) wurde durch seinen exogenen Liganden 3MC in der Konzentration $1 * 10^{-6} \mathrm{M}$ um ca. 30\% gesteigert, jedoch nicht signifikant zur Kontrolle. Auch in Koinkubation mit Estradiol sowie 4MBC in der Konzentration $5 * 10^{-5} \mathrm{M}$ war die Erhöhung der mRNA-Expression, bei Estradiol um ca. 48\% bzw. bei 4MBC um 61\%, nicht signifikant. Die Inkubation der Zellkultur mit Estradiol sowie 4MBC alleine hatte keinen Effekt auf die Genexpression des AhR. 


\section{H 4 IIE - G e nexpression}

AhR

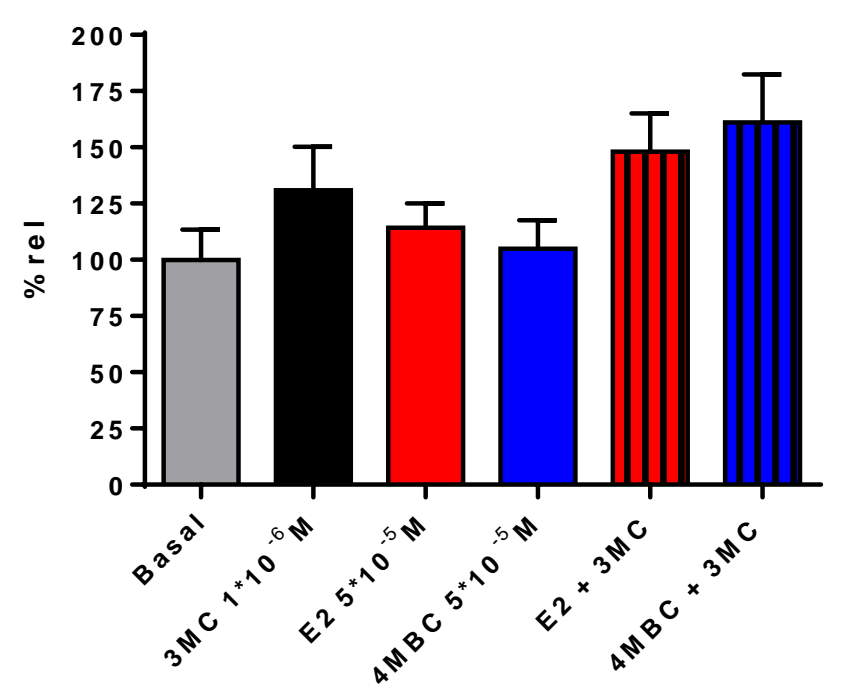

Abbildung 19: AhR-Genexpression (RT-PCR) in der H4IIE-Zellkultur nach 48h Inkubation. Die Werte ( $\mathrm{n}=12$, 3 Experimente mit 4 Replikaten) wurden auf die Kontrollgruppe (Basal) relativiert.

\subsubsection{Genexpression ARNT}

Die Genexpression des AhR-Dimerisierungspartners ARNT (aryl hydrocarbon receptor nuclear translocator) (Abbildung 20) wurde durch die Inkubation mit dem Liganden 3MC sowie den Testsubstanzen Estradiol und 4MBC sowohl einzeln als auch in Kombination nicht signifikant beeinflusst.
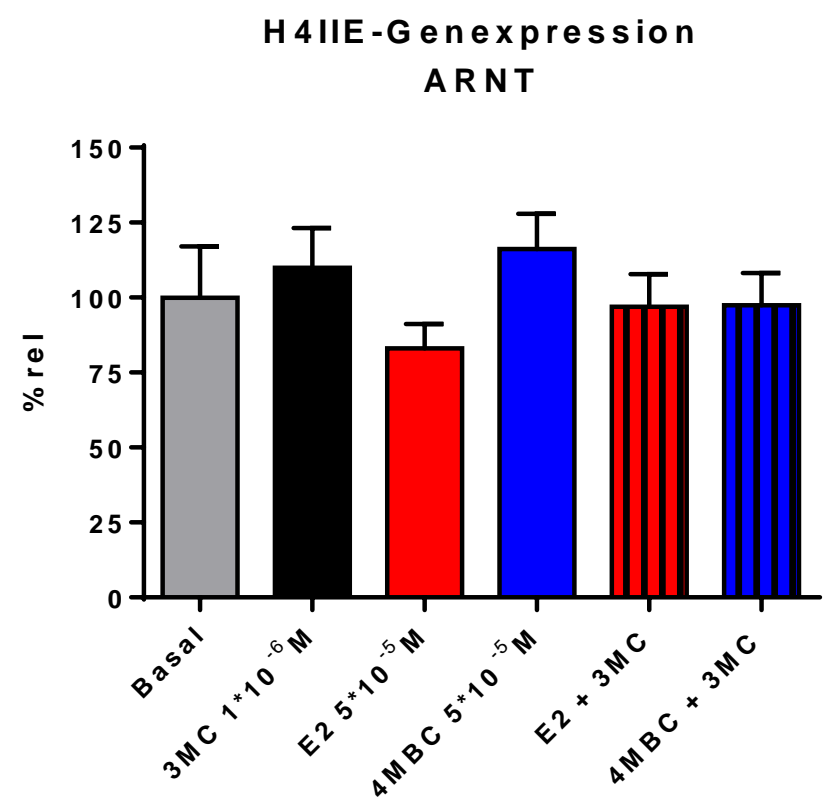

Abbildung 20: ARNT-Genexpression (RT-PCR) in der H4IIE-Zellkultur nach 48h-Inkubation. Die Werte ( $\mathrm{n}=12$, 3 Experimente mit 4 Replikaten) wurden auf die Kontrollgruppe (Basal) relativiert. 


\subsection{Tierversuchsdaten}

Da Untersuchungsergebnisse in vitro in besonderem Maße abhängig sind von den gewählten Begleitumständen wie der Zellkultur, der Konzentration der Substanzen oder dem Testsystem, wurde in einem Tierversuch mit Wildtyp-Mäusen überprüft, ob die zusätzliche Behandlung mit Estradiol bzw. 4MBC die Induktion des AhR-Signalweges durch 3MC moduliert.

Im Folgenden werden die Ergebnisse aus dem Tierversuch „Subakute Applikation von Testsubstanzen“ dargestellt.

\subsubsection{Tier- und Organgewichte}

\subsubsection{Tiergewichte}

Vor Beginn der Behandlung lag das durchschnittliche Körpergewicht der 3-4 Monate alten männlichen Mäuse bei 28,46 \pm 1,2 g. In allen Behandlungsgruppen konnte bei Versuchsende am dritten Behandlungstag im Hinblick auf die Tiergewichte kein signifikanter Unterschied zur Kontrollgruppe festgestellt werden (Abbildung 21).

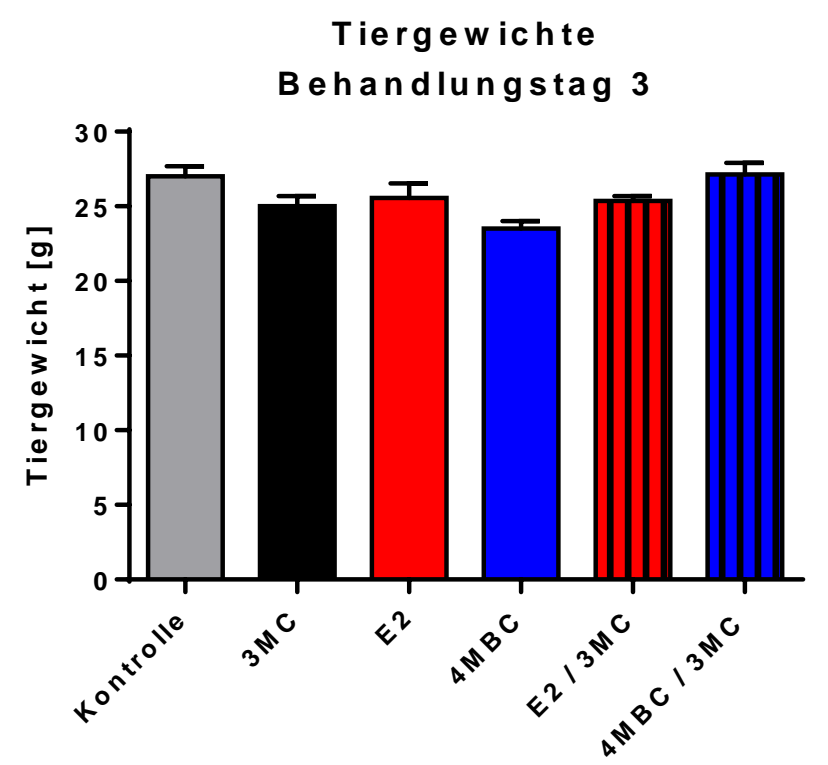

Abbildung 21: Tiergewichte der Behandlungsgruppen bei Versuchende (Behandlungstag 3). Eine Behandlungsgruppe umfasste 10 Tiere. 


\subsubsection{Lebergewichte}

Als Umweltkontaminant induziert 3MC in besonders ausgeprägtem Maße den Fremdstoffmetabolismus der Leber. Wie in Abbildung 22 dargestellt, resultierte die alleinige Applikation von 3MC im Verlauf von drei Behandlungstagen aber nicht in einer signifikanten Abweichung des relativen Lebergewichts in Bezug auf die Kontrollgruppe, bei der das Lebergewicht ca. 5,1 \% vom Körpergewicht betrug. Mit Ausnahme der Behandlungsgruppe 4MBC/3MC wiesen auch alle anderen Gruppen keine signifikante Änderung des relativen Lebergewichtes in Bezug zu der Kontrollgruppe auf. Die kombinierte Applikation von 4MBC und 3MC führte in dieser Gruppe zu einer signifikanten Reduktion des relativen Lebergewichtes um ca. $15 \%$.

\section{Lebergewicht/B W}

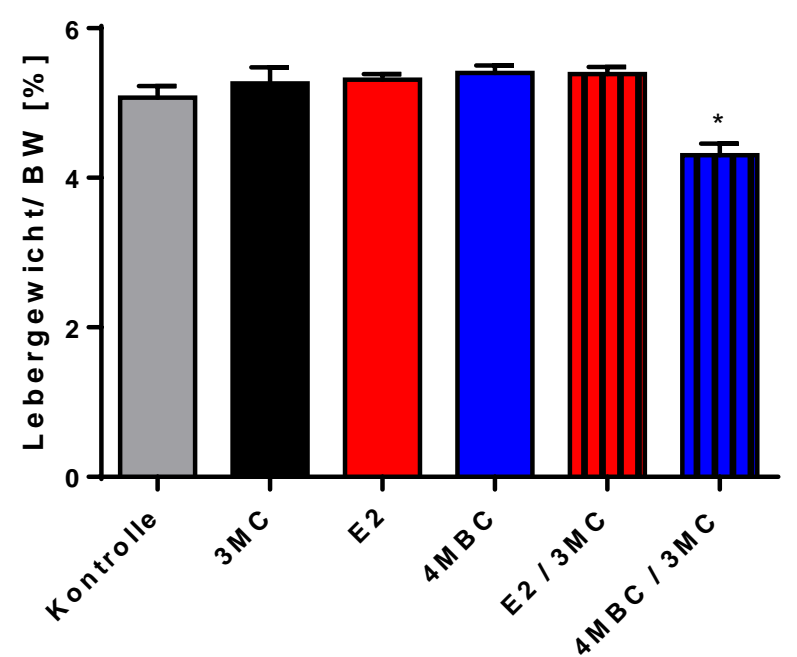

Abbildung 22: Relative Lebergewichte der Behandlungsgruppen bei Versuchsende (Behandlungstag 3). Das Lebergewicht wurde auf das Körpergewicht (BW) der einzelnen Tiere bezogen. * = signifikant gegen die Kontrollgruppe. 


\subsubsection{Serumanalyse}

Die Serumspiegel von Estradiol wurden im Radioimmunoassay ermittelt. Wie in Abbildung 23 dargestellt, konnten nur die Serumspiegel der Behandlungsgruppen Estradiol (E2) und der Kombination E2 mit 3MC quantifiziert werden. Die dreitägige Behandlung mit E2 führte im Serum der männlichen Versuchstiere zu einer mittleren Serumkonzentration $646 \pm 365$ pg/ml. Auch die kombinierte Behandlung mit E2 und 3MC resultierte in einem Anstieg des Estradiolspiegels auf $427 \pm 330 \mathrm{pg} / \mathrm{ml}$. Die durchschnittliche Serumkonzentration bei der Gruppe E2/3MC war dementsprechend geringer als die der Gruppe E2 trotz gleicher Zufuhr von E2 bei beiden Behandlungsgruppen. Dieser Unterschied wies jedoch in einem separaten student's t-test keine Signifikanz auf.

\section{Serum spiegel Estradiol}

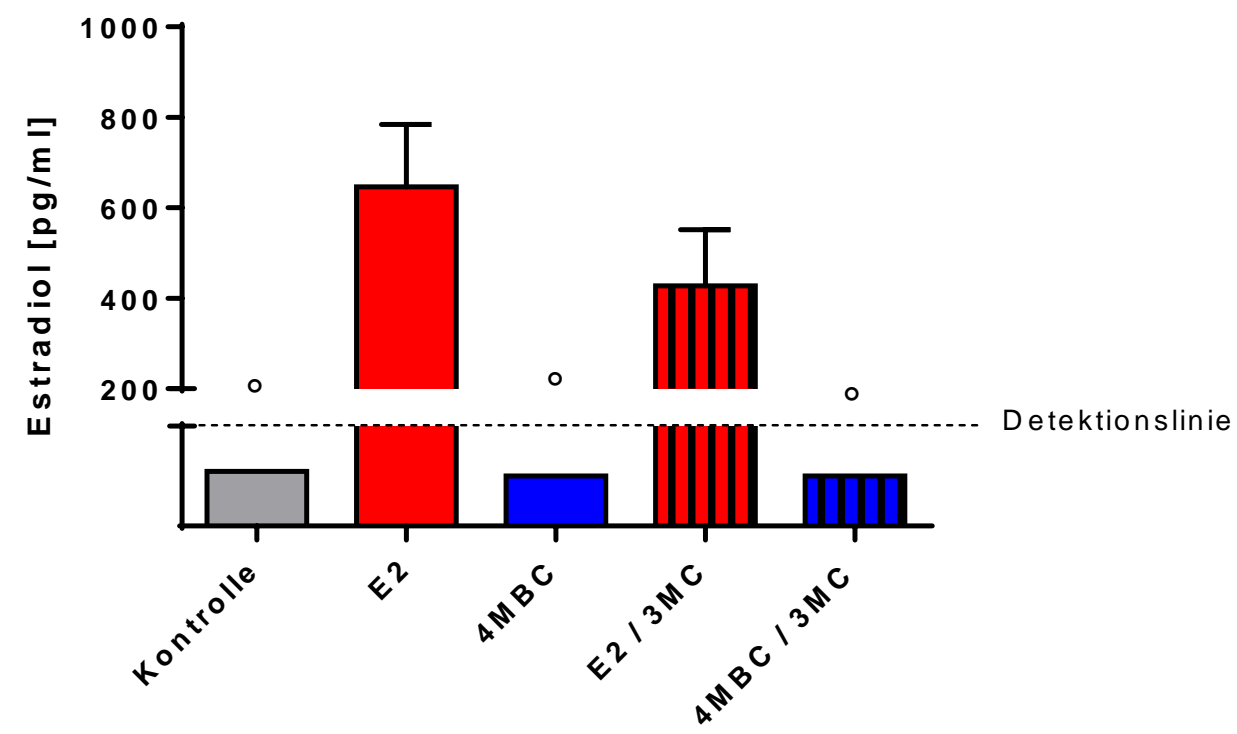

Abbildung 23: Serumspiegel von Estradiol nach 3tägiger Behandlung. Pro Tier konnten ca. $150 \mu \mathrm{l}$ Serum gewonnen werden, allerdings wurden für den vorliegenden Radioimmuniassay in Doppelbestimmung $200 \mu \mathrm{l}$ Serum benötigt, weshalb die Werte der Behandlungsgruppen ohne E2-Gabe unterhalb der Detektionslinie des Assays lagen (०). Eine Behandlungsgruppe umfasste 10 Tiere.

\subsubsection{Genexpressionsdaten der Leber}

Um Auswirkungen der Applikationsbehandlung auf die Genexpression der Leber in den Behandlungsgruppen darzustellen, wurde die mRNA-Expression von CYP1A1, AhR, ARNT und ER $\alpha$ nach der dreitägigen Behandlung mittels RT-PCR analysiert. 


\subsubsection{Genepression von Cyp1A1}

Abbildung 24 zeigt die CYP1A1-Genexpression in der Leber. Wie von dem CYP1A1Induktor 3MC zu erwarten war, führte die dreitägige Behandlung mit 3MC bei dieser Gruppe zu einer ca. 1000fachen Steigerung der CYP1A1-Expression. Die kombinierte Gabe von E2 und 3MC führte zu einer ca. 1600fachen Induktion der CYP1A1-mRNA, die Kombination von 4MBC und 3MC wies einen ca. 2900fachen Anstieg in Bezug auf die Kontrollgruppe auf. Die deutlich stärkeren CYP1A1-Induktionen durch die kombinierten Behandlungen stellten sich in einem zusätzlichen ANOVA jedoch als nicht signifikant gegenüber der alleinigen Gabe von 3MC heraus. Die alleinige Applikation von E2 sowie 4MBC führte zu keiner signifikanten Änderung der CYP1A1-Genexpression.
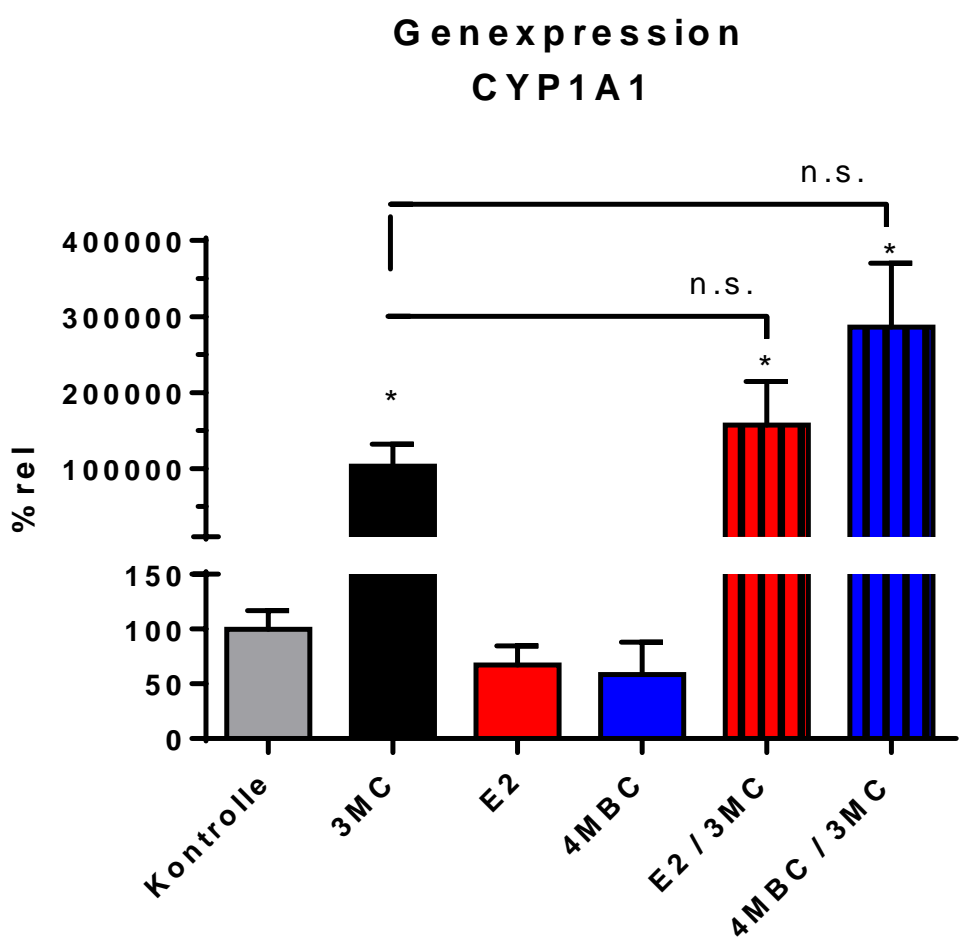

Abbildung 24: CYP1A1-Genexpression (RT-PCR) in der Leber nach 3tägiger Behandlung. Die Werte $(\mathrm{n}=10)$ wurden auf die Kontrollgruppe relativiert. * = signifikant gegen die Kontrollgruppe.

\subsubsection{Genexpression von AhR und ARNT}

Die Genexpressionen des Arylhydrocarbon-Rezeptors (AhR) sowie dessen Dimerisierungspartners ARNT in der Leber der Behandlungsgruppen sind in Abbildung 25 dargestellt. Diese zeigt sowohl bei der Gabe von dem AhR-Liganden 3MC als auch bei der Behandlungsgruppe E2 eine Reduktion der AhR-Genexpression auf ca. 70\% bzw. ca. 75\% der Kontrolle, die sich jedoch in beiden Fällen als nicht signifikant herausstellte. Ebenso wies die 
leichte Steigerung der AhR-Expression in der Kombinationsgruppe 4MBC/3MC von 22\% keine Signifikanz auf. Die AhR-Genexpression in den Gruppen 4MBC und E2/3MC blieb unverändert. Die mRNA-Expression von ARNT zeigte in allen Behandlungsgruppen, mit Ausnahme der kombinierten Gruppe 4MBC/3MC, keine signifikante Änderung. In dieser Gruppe steigerte die Behandlung die ARNT-Genexpression um ca. 38\%.

$$
\text { Genexpression }
$$

Ah-R

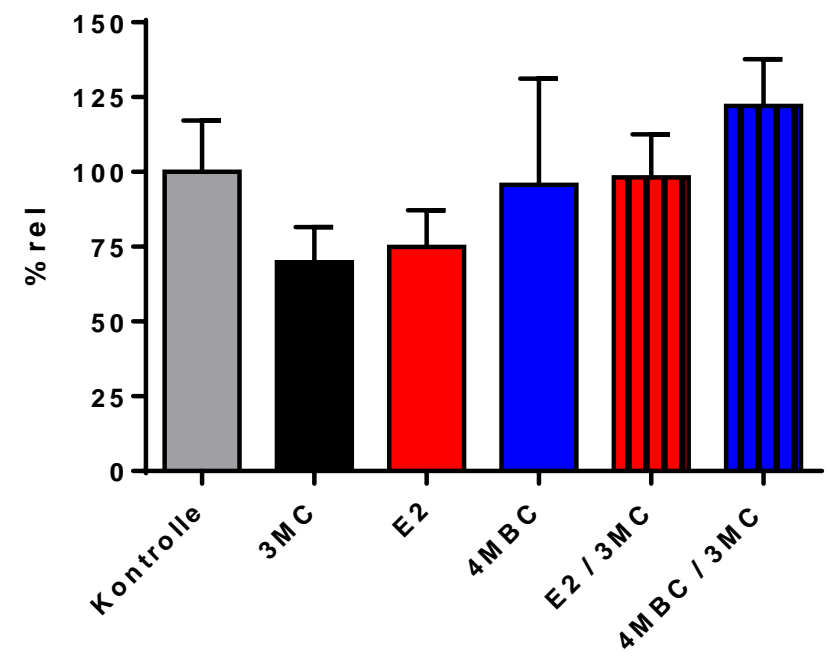

Genexpression

AR N T

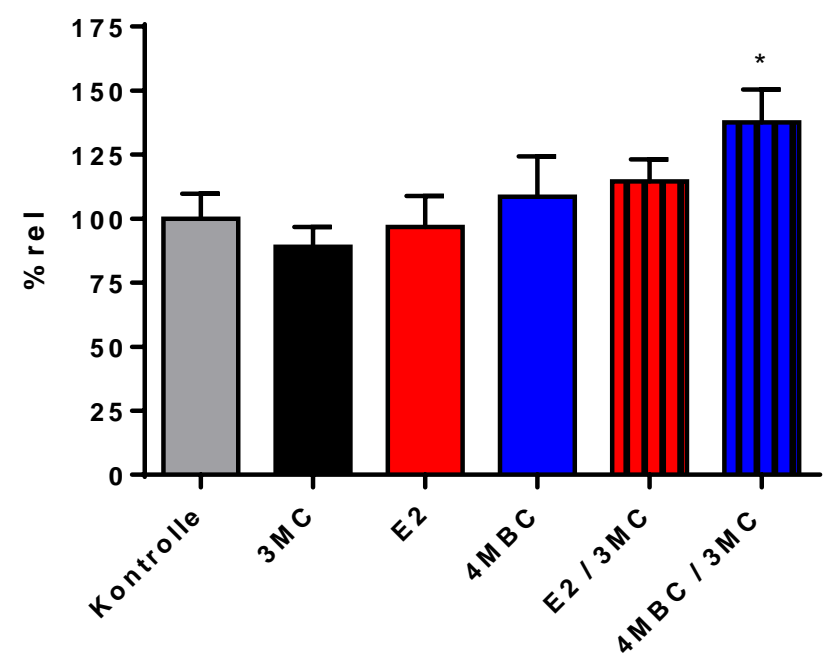

Abbildung 25: AhR- und ARNT-Genexpression (RT-PCR) in der Leber nach 3tägiger Behandlung. Die Werte $(n=10)$ wurden auf die Kontrollgruppe relativiert. * = signifikant gegen die Kontrollgruppe. 


\subsubsection{Genexpression von ERa}

Auch die mRNA-Expression von ER $\alpha$ in der Leber der Behandlungsgruppen wurde mittels RT-PCR analysiert (Abbildung 26). Dabei wies keine der Behandlungsgruppen eine signifikante Änderung der Genexpression auf. Die Behandlungsgruppen E2 und 4MBC/3MC zeigten zwar eine reduzierte Expression von ER $\alpha$ auf ca. 78 \% bzw. ca. 65\%, diese blieb jedoch unterhalb des Signifikanzniveaus.
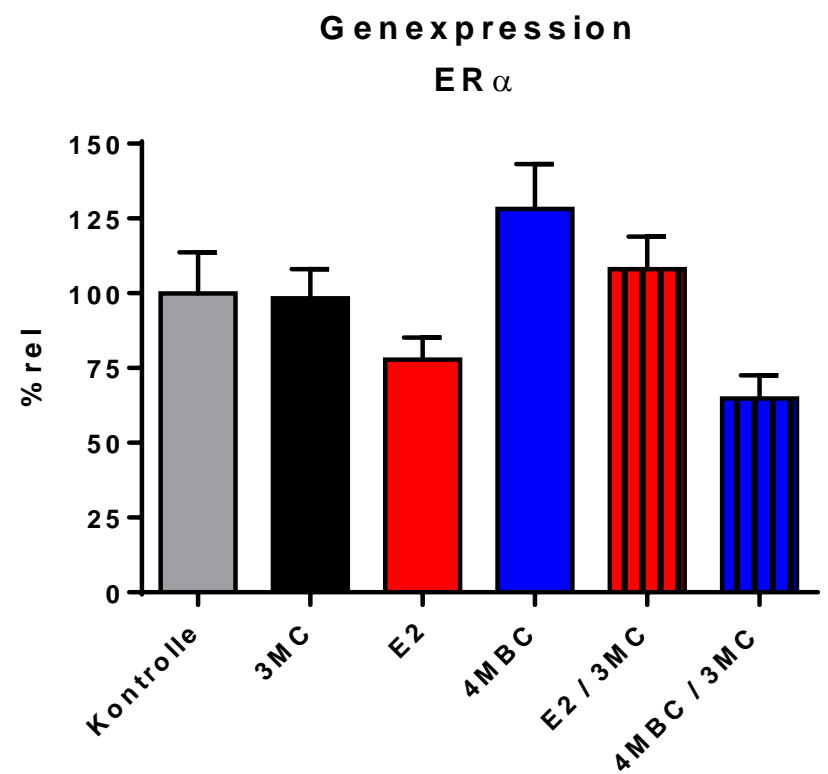

Abbildung 26: ERa-Genexpression (RT-PCR) in der Leber nach 3tägiger Behandlung. Die Werte $(n=10)$ wurden auf die Kontrollgruppe relativiert. 


\subsection{EROD-Assay mit Zellhomogenat}

Um Aufschluss über mögliche direkte Effekte der Testsubstanzen auf die Reaktion des EROD-Assays unter Ausschluss der Genexpression zu erhalten, wurde dieser mit einem Zellhomogenat durchgeführt. Das Homogenat wurde aus der H4IIE-Zellkultur gewonnen, deren CYP1A1-Genexpression zuvor durch 3MC $\left(1 * 10^{-6} \mathrm{M}\right)$ induziert worden war, um eine möglichst hohe Enzymausbeute zu erreichen. Parallel mitgeführte Kontrollen ohne NADP bzw. Homogenat gaben Aufschluss über die Funktionsfähigkeit des eingesetzten IsocitratDehydrogenase/Isocitrat-Redoxsystems bzw. über die Abhängigkeit der Enzymreaktion von vorhandenem Zellhomogenat.

\subsubsection{Resorufinzeitprodukt}

Eine Analyse im Hinblick auf die Abhängigkeit des Reaktionsproduktes Resorufin von der Reaktionszeit des EROD-Assays (Abbildung 27) zeigte eine streng lineare Beziehung mit einem Bestimmtheitsmaß von $r^{2}=0,992$ und einer Steigung von $y=1,48 * x$.

\section{EROD-Assay mit Zellhomogenat \\ Produkt-Zeit-Beziehung}

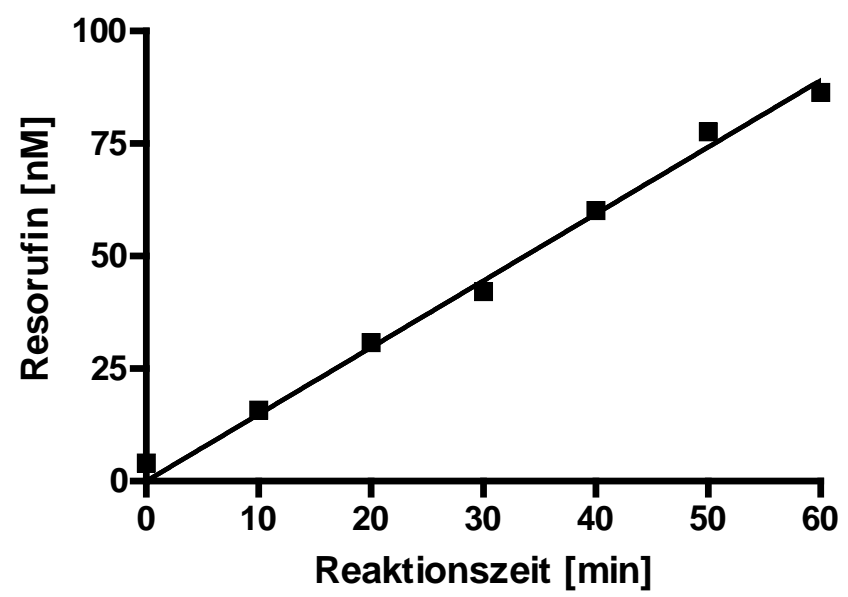

Abbildung 27: Abhängigkeit des Reaktionsproduktes Resorufin von der Reaktionszeit im EROD-Assay mit dem Zellhomogenat aus der H4IIE-Zellkultur. Die Proteinkonzentration des Zellhomogenats wurde auf $1 \mathrm{mg} / \mathrm{ml}$ festgelegt und die Reaktion mit $5 \mu \mathrm{l} 75 \mu \mathrm{M}$ Ethoxyresorufin gestartet. 


\subsubsection{EROD-Assay mit 3MC}

In einer Verdünnungsreihe des CYP1A1-Induktors 3MC (Abbildung 28) wurde dessen direkte Wirkung auf die Enzymreaktion des EROD-Assays untersucht. Der Zusatz von 3MC führte dabei ab einer Konzentration von $1 * 10^{-8} \mathrm{M}$ zu einer sehr deutlichen Hemmung der EROD-Aktivität. Die maximale Reduktion betrug innerhalb der getesteten Konzentrationen $\left(1 * 10^{-10} \mathrm{M}\right.$ bis $\left.1 * 10^{-4} \mathrm{M}\right)$ ca. $94 \%$ bei $1 * 10^{-5} \mathrm{M}$.

\section{EROD-Assay $m$ it Zellhomogenat \\ 3 M C}

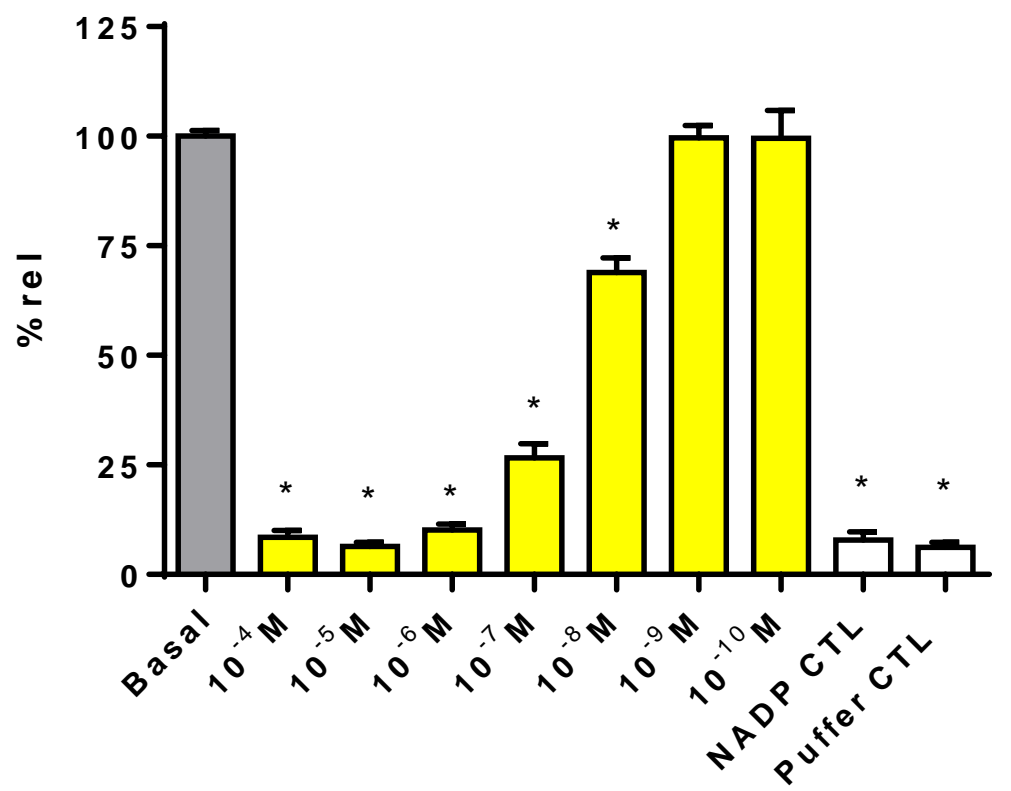

Abbildung 28: Hemmung der EROD-Aktivität im EROD-Assay mit Zellhomogenat durch 3MC. Die Werte ( $n=6$, 3 Experimente mit 2 Replikaten) wurden auf die Kontrollgruppe (Basal) relativiert. NADP CTL = Reaktionsansatz ohne Zusatz von NADP. Puffer CTL = Reaktionsansatz mit Puffer ohne Homogenat. * = signifikant gegen die Gruppe „Basal“. 


\subsubsection{EROD-Assay mit Estradiol und 4MBC}

In Abbildung 29 ist die Wirkung von Estradiol sowie 4MBC auf die Reaktion des ERODAssays dargestellt. Beide Testsubstanzen hemmten die EROD-Aktivität deutlich dosisabhängig und in allen getesteten Konzentrationen signifikant. Die Reduktion durch den Zusatz von Estradiol steigerte sich graduell von $19 \%$ bei $1 * 10^{-6} \mathrm{M}$ zu maximal $80 \%$ bei $1^{*} 10^{-4} \mathrm{M}$, die Reduktion durch $4 \mathrm{MBC}$ von $16 \%$ bei $1 * 10^{-6} \mathrm{M}$ zu maximal $87 \%$ bei $1 * 10^{-4} \mathrm{M}$.

\section{EROD-Assay mit Zellhomogenat Estradiol und $4 \mathrm{MBC}$}

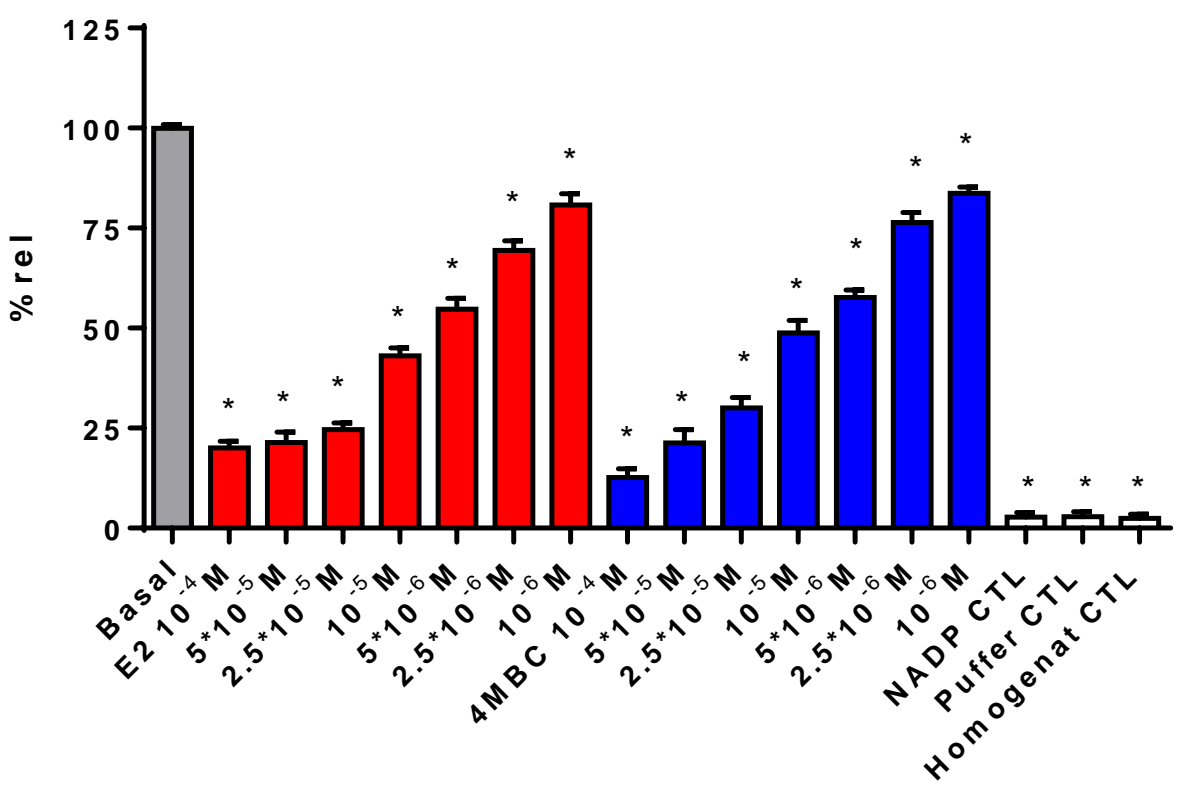

Abbildung 29: Hemmung der EROD-Aktivität im EROD-Assay mit Zellhomogenat durch Estradiol und 4MBC. Die Werte ( $n=6,3$ Experimente mit 2 Replikaten) wurden auf die Kontrollgruppe (Basal) relativiert. NADP CTL = Reaktionsansatz ohne Zusatz von NADP. Puffer CTL = Reaktionsansatz mit Puffer ohne Homogenat. Homogenat CTL $=$ Reaktionsansatz mit Zellhomogenat von nicht vorbehandelter Zellkultur. * = signifikant gegen die Gruppe „Basal“. 


\subsubsection{EROD-Assay mit E2-verwandten Substanzen}

Um die (strukturellen) Eigenschaften der Substanzen einzugrenzen, die für einen direkten Einfluss auf die Enzymreaktion des EROD-Assays maßgebend sein könnten, wurde die EROD-Aktivität unter Zusatz von verschiedenen Substanzen, unter anderem aus dem Bereich der Steroidhormone, in der Konzentration $1^{*} 10^{-5} \mathrm{M}$ gemessen. Dabei zeigte sich bei den schon zuvor getesteten Substanzen 3MC, 17 $\beta$-Estradiol und 4MBC erneut eine starke Hemmung der EROD-Aktivität. Der CYP1A1-Induktor 3MC reduzierte die gemessene Enzymaktivität auf $7 \%$ der Kontrolle, 17 $\beta$-Estradiol auf $46 \%$ und $4 \mathrm{MBC}$ auf $49 \%$. Eine signifikante Erniedrigung zeigte ebenso der Zusatz von dem Stereoisomer 17 $\alpha$-Estradiol auf 84\% sowie von dem Estrogen Estron auf 58\%. Das estrogene Stoffwechselprodukt Estriol als auch die Vertreter anderer Steroidhormone - Progesteron, Testosteron und Corticosteron - wiesen dagegen keine direkte Wirkung auf die Reaktion des EROD-Assays auf. Das Phytoestrogen Genistein senkte die EROD-Aktivität auf 31\% der Kontrolle, auch der Zusatz des SERMs (Selektiver Estrogenrezeptormodulator) Raloxifen reduzierte diese auf 57\%. Der Estrogenrezeptor-Antagonist ICI 182,780 hatte keinen signifikanten direkten Effekt auf die Enzymaktivität.

\section{EROD-Assay $m$ it Zellhomogenat \\ verschiedene Testsubstanzen}

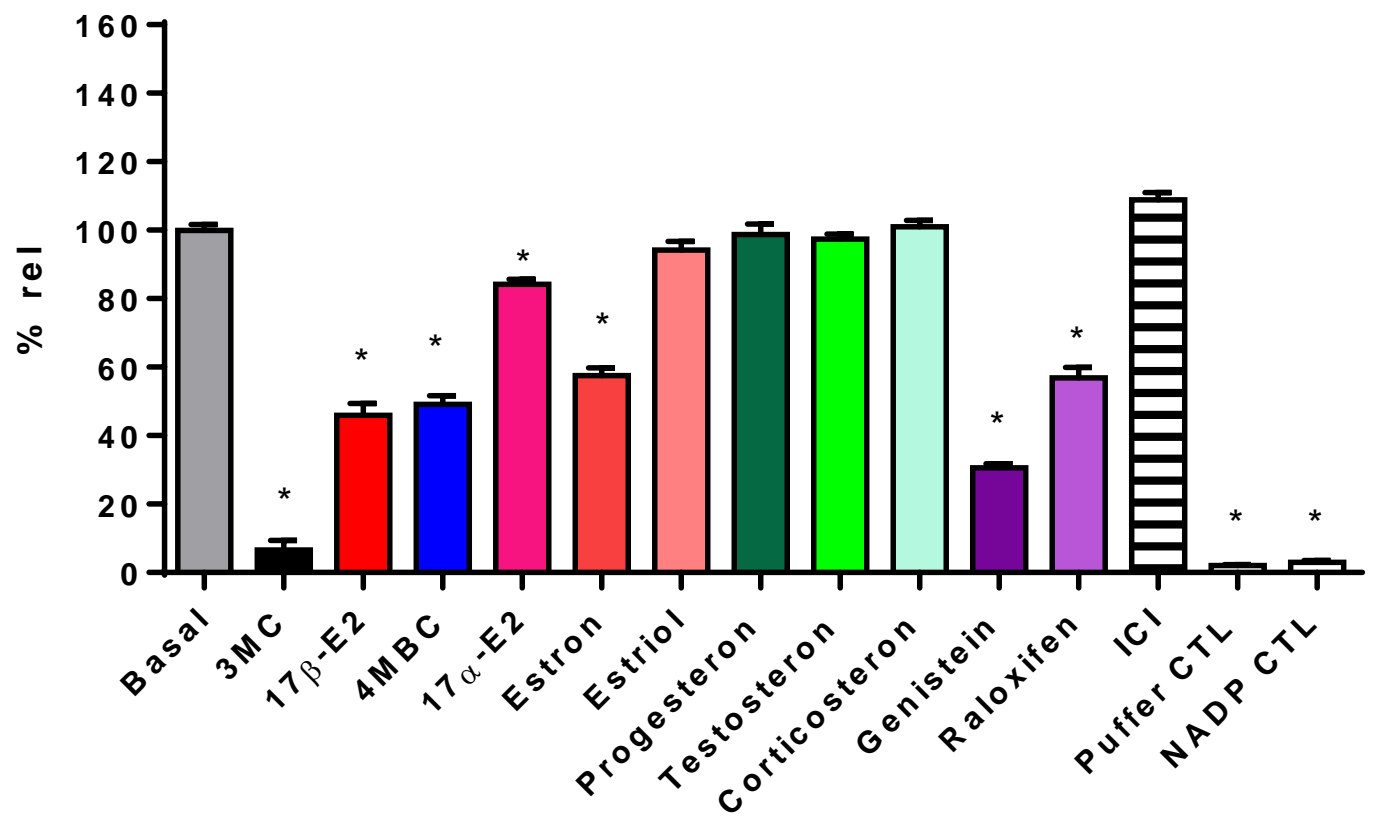

Abbildung 30: Einfluss von verschiedenen Testsubstanzen $\left(1 * 10^{-5} \mathrm{M}\right)$ auf die EROD-Aktivität im ERODAssay mit Zellhomogenat. Die Werte ( $\mathrm{n}=6$, 3 Experimente mit 2 Replikaten) wurden auf die Kontrollgruppe relativiert (Basal). NADP CTL = Reaktionsansatz ohne Zusatz von NADP. Puffer CTL = Reaktionsansatz mit Puffer ohne Homogenat. * = signifikant gegen die Gruppe „Basal“. 


\section{Diskussion}

In der vorliegenden Arbeit konnte anhand der durchgeführten Methoden die Annahme einer Hemmung der AhR-Zielgene auf transkriptioneller Ebene durch Estradiol und dem Xenoöstrogen 4MBC nicht bestätigt werden. Die durchgeführte Genexpressionsanalyse zeigte keinen signifikanten inhibitorischen Effekt von Estradiol oder 4MBC auf die Transktiption des AhR-Zielgens CYP1A1.

Direkt konträr hierzu wiesen dagegen die Ergebnisse des EROD-Assays an der H4IIEZellkultur einen sehr starken inhibitorischen Einfluss von Estradiol und 4MCB auf die CYP1A1-Enzymaktivität auf. Als Ursache dieser zunächst widersprüchlichen Ergebnisse konnte ein gravierender Störfaktor in der verwendeten Methode herausgearbeitet werden: Die kompetitive Inhibition des CYP1A1-Enzyms im EROD-Assay durch Estrogen, estrogenähnliche Substanzen sowie auch den verwendeten AhR-Induktor 3MC reduziert die Validität des Testsystems in erheblichem Umfang.

Schlußfolgernd bedürfen Untersuchungen bezüglich einer AhR-ER $\alpha$-Interaktion sowie auch die Einschätzung von Expositionen gegenüber dioxinähnlichen Stoffen mittels EROD-Assay einer detallierten Kenntnis und den Ausschluss der beschriebenen Störfaktoren.

\subsection{Modifikation der induzierten CYP1A1-Aktivität im Zellkultur-}

\section{EROD-Assay}

Der 7-Ethoxyresorufin-O-deethylase-(EROD)-Assay an einer vitalen Zellkultur soll als schnell durchführbarer Bioassay als Indikator für die Exposition gegenüber einem dioxinähnlichen Stoff fungieren, welcher an den AhR bindet und über die beschriebene Signalkaskade die Aktivität des CYP1A1-Enzyms induziert. Entsprechend wird eine erhöhte Enzymaktivität einer erhöhten Genexpression und zusätzlich dem Ausmaß der Induktion der Konzentration des induzierenden Stoffes gleichgesetzt (Petrulis und Bunce 1999).

\subsubsection{Auswirkung von 3MC}

Wie von 3MC als Modell-Ligand des AhR zu erwarten, zeigte sich im EROD-Assay eine starke, in niedrigeren Konzentrationen dosisabhängige CYP1A1-Induktion mit einem Maximum einer 120 fachen Erhöhung bei einer Konzentration von $1^{*} 10^{-6} \mathrm{M}$. In höheren 
Konzentrationen unterschied sich die EROD-Aktivität nicht mehr signifikant von der Basalaktivität. Dieses Phänomen wurde bereits in mehreren Studien mit unterschiedlichen Studienbedingungen nachgewiesen. Gooch et al. beobachteten in höheren Konzentrationen in vivo eine starke Reduktion der durch Polychlorierte Biphenyle induzierten CYP1A1-Aktivität im EROD-Assay an Mikrosomen der Meerbrasse (Gooch et al. 1989), Hahn et al. bei höheren Konzentrationen von Tetrachlorbiphenyl als $1 * 10^{-7} \mathrm{M}$ in einer Fischhepatom-Zellkultur. Jedoch stieg die Genexpression bzw. CYP1A1-Proteinmenge jeweils dosisabhängig weiter an (Hahn et al. 1993). Eine Zytotoxizität der verwendeten Xenobiotika in höherer Dosierung wurde durch Verhallen et al. bei einer TCDD-Behandlung von Hühner-Primärzellkultur in $1 * 10^{-7} \mathrm{M}$ widerlegt (Verhallen et al. 1997) und kann somit nicht als Erklärung herangezogen werden.

\subsubsection{Auswirkung von Estradiol, 4MBC und ICI}

Estradiol allein wies im EROD-Assay der H4IIE-Zellkultur bis zu einer Konzentration von $2.5^{*} 10^{-5} \mathrm{M}$ keinen Einfluss auf die basale CYP1A1-Aktivität auf. Lee et al. berichteten dagegen von einer Erhöhung der CYP1A1-Aktivität durch $1 * 10^{-5} \mathrm{M}$ Estradiol. Bei zusätzlicher Induktion der CYP1A1-Genexpression wird dort die Hypothese des Estradiols als eines moderaten AhR-Liganden vertreten. (Lee SS et al. 1998). Dies lässt sich anhand der hier erlangten Ergebnisse so nicht bestätigen. Auch Son et al. konnte keinen Effekt von Estradiol allein nachweisen (Son et al. 2002).

Desweiteren konnte in dieser Arbeit eine ausgeprägt signifikante und dosisabhängige Hemmung der 3MC-induzierten CYP1A1-Aktivität durch Estradiol ab einer Konzentration von $2,5^{*} 10^{-6} \mathrm{M}$ gezeigt werden. Diesbezüglich ist die Datenlage sowie deren Interpretation als kontrovers zu beschreiben. Während Hoivik et al. sowohl bei MCF-7 (Mammakarzinom)sowie auch Hepa1c1c7 (Maushepatom)-Zellen bei E2 von $1 * 10^{-9} \mathrm{M}$ keinerlei Effekt auf die induzierte CYP1A1-Aktivität nachweisen konnten (Hoivik et al. 1997), war es anderen Gruppen möglich den hemmenden Effekt durch E2 auf MCF-7- und ECC-1 (Endometriumepithel)-Zellen bereits bei Konzentrationen ab $1 * 10^{-9} \mathrm{M}$ (Ricci et al. 1999; Wormke et al. 2000) zu demonstrieren. Son et al. erreichten durch gleichzeitige Behandlung mit E2 von $5 * 10^{-6} \mathrm{M}$ und TCDD bei ID8(Mausovar)-Zellen sogar eine stärkere Aktivierung des CYP1A1 als durch TCDD allein (Son et al. 2002).

Ricci et al. sahen eine mögliche Begründung für den divergierenden Effekt in der Abhängigkeit von der Estrogensensitivität und ER-Status der Zellkultur. Dies erscheint im 
Hinblick auf die hier verwendete Hepatom-Zellkultur und die fehlende Hemmung in Ishikawa-Zellen (Endometriumkarzinom) fragwürdig (Wormke et al. 2000). Auch bei Fischen ist die estrogene Hemmung der induzierten CYP1A1-Aktivität in vivo und in vitro nachweisbar (Kirby et al. 2007; Grans et al. 2010).

Unklar ist bisher die Involvierung des ER $\alpha$ überhaupt in die estrogenbedingte Hemmung der induzierten CYP1A1-Aktivität. In der vorliegenden Arbeit wurde der EstrogenrezeptorAntagonist ICI $182,780\left(1 * 10^{-6} \mathrm{M}\right)$, welcher inzwischen als Fulvestrant in der Brustkrebstherapie Verwendung findet, hinzugezogen, um eine weitere Beschreibung des Effektes zu ermöglichen. ICI zeigte in der Koinkubation mit 3MC und E2 keinen Einfluss auf die Hemmung durch E2. Damit scheint die Wirkung des Estradiols nicht über den typischen ER-Signalweg zu entstehen, was im Gegensatz zu den erwarteten Ergebnissen einer Interaktion auf Rezeptorebene steht. Auch diesbezüglich ist die Datenlage sehr unstimmig. Sowohl ICI als auch der selektive Estrogantagonist Tamoxifen, welcher kompetitiv an den ER bindet, konnten teilweise die estradiolbedingte Hemmung aufheben (Ricci et al. 1999; Wormke et al. 2000). Andere Studien konnten dies jedoch nicht bestätigen (Jeong und Lee 1998; Lai et al. 2004).

Zumindest teilweise gibt das Modell von Wormke et al. für die kontroversen Ergebnisse eine Erklärung, welches die unterschiedlichen Expressionsmuster verschiedenster Transkriptionsfaktoren in den Zellkulturen und deren Variabilität innerhalb derselben Zelllinie durch Wachstumsbedingungen und Zellpassagen als ursächlich ansehen (Wormke et al. 2000; Safe und Wormke 2003).

Das Xenoöstrogen 4MBC zeigte bis zu einer Konzentration von $5 * 10^{-5} \mathrm{M}$ im EROD-Assay ebenso wie Estradiol keinen signifikanten Einfluss auf die basale CYP1A1-Aktivität, so dass eine Bindung an den AhR und Induktion des Signalweges damit ausgeschlossen scheinen. Interessanterweise ließ sich auch bei 4MBC der zuvor für Estradiol beschriebene ausgeprägt hemmende Effekt auf die induzierte CYP1A1-Aktivität ab einer Konzentration von $2.5^{*} 10^{-5} \mathrm{M}$ nachweisen. Für das Xenoöstrogen wurde zuvor zwar die estrogene Wirksamkeit über die Estrogenrezeptoren (ERß vornehmlicher als ER $\alpha$ ) bestätigt, allerdings war das estrogene Potential geringer als von Phytoöstrogenen wie beispielsweise Genistein (Mueller et al. 2003). Somit ist die fast äqivalente Hemmung der CYP1A1-Aktivität im EROD-Assay bei einer Konzentration von $5 * 10^{-5} \mathrm{M}$ von Estradiol und $4 \mathrm{MBC}$ nicht zu erwarten gewesen. 
Passend zu dieser Parallelität wurde auch bei 4MBC die hemmende Wirkung durch zusätzlich inkubiertes ICI nicht aufgehoben.

\subsubsection{Auswirkung durch E2-ähnliche Substanzen}

Um Hinweise darauf zu erhalten, inwiefern die molekulare Struktur der Testsubstanz Einfluss auf deren Wirkung im EROD-Assay aufweist, wurden strukturell ähnliche Substanzen (17 $\alpha$ Estradiol, Estron, Estriol, Testosteron und Genistein) im EROD-Assay der H4IIE-Zellkultur bei einer Konzentration von $5 * 10^{-5} \mathrm{M}$ getestet. Dabei wies das Isoflavon und bekannte Phytoöstrogen Genistein eine 2,5fache Induktion der basalen CYP1A1-Aktivität gegenüber der Kontrolle auf. Eine leicht induzierende Wirkung wurde bereits durch Shertzer et al. beschrieben (Shertzer et al. 1999). Das Stereoisomer 17 $\alpha$-Estradiol, das Estrogen Estron sowie das estrogene Stoffwechselprodukt Estriol hatten in der gemessenen Konzentration keinen induzierenden Effekt. Auch bei der Inkubation mit Testosteron konnte keine Steigerung der EROD-Aktivität gegenüber der Kontrolle festgestellt werden.

Im Hinblick auf einen Einfluss der durch 3MC induzierten EROD-Aktivität konnte bei allen Estrogenen eine Hemmung unterschiedlichen Ausmaßes nachgewiesen werden. Damit scheint es einen deutlichen Zusammenhang zwischen der hemmenden Wirkung und der estradiolähnlichen Molekülstruktur zu geben. Son et al. hatten diese Beobachtung für Estriol bereits beschrieben (Son et al. 2002). Testosteron sowie Genistein zeigten hingegen keine Wirkung auf die induzierte CYP1A1-Aktivität. Für Testosteron stimmt dieses Ergebnis mit Lai et al. überein (Lai et al. 2004), nicht jedoch mit Jana et al., welche bei einer Konzentration ab $1 * 10^{-8} \mathrm{M}$ eine Hemmung der TCDD-induzierten Aktivität bei LNCaP-Prostatakarzinomzellen nachgewiesen hatten (Jana et al. 1999). Shertzer et al. schilderten - im Gegensatz zu den Beobachtungen hier - eine hemmende Wirkung von Genistein auf die induzierte ERODAktivität (Shertzer et al. 1999). Da Genistein selbst jedoch leicht induzierend wirkt, könnten sich bei den durchgeführten Versuchen beide Effekte gegenseitig aufgehoben haben, so dass keine signifikante Beeinflussung festgestellt werden konnte.

\subsection{Modifikation der Genexpression in der H4IIE-Zellkultur}

\subsubsection{Auswirkung auf die Genexpression von CYP1A1}

Passend zu den Ergebnissen des EROD-Assays zeigte sich die CYP1A1-Genexpression nach der Induktion durch den AhR-Liganden 3MC 108fach erhöht. Die alleinige Inkubation mit 
Estradiol bzw. 4MBC zeigte ebenso entsprechend des EROD-Assays keine Induktion des AhR-Signalweges in Abwesenheit von 3MC, welches sich mit anderen Studien deckt (Kharat und Saatcioglu 1996).

Die reduzierte CYP1A1-Aktivität im EROD-Assay durch Koinkubation von 3MC mit Estradiol sollte in der RT-PCR durch eine erniedrigte CYP1A1-Genexpression bestätigt werden. Trotz der unter 4.1.2 beschriebenen Divergenz der Studienergebnisse bezüglich der Modulation des EROD-Assays durch Estradiol waren die Beobachtungen von EROD-Assay und CYP1A1-Genexpression in den jeweiligen Studien übereinstimmend gewesen (Lee SS et al. 1998; Ricci et al. 1999; Lai et al. 2004). Diese Annahme konnte jedoch in den hier durchgeführten Untersuchungen nicht nachgewiesen werden. Sowohl Estradiol als auch 4MBC hatten keinen hemmenden Einfluß auf die 3MC-induzierte Genexpression von CYP1A1. Im Gegensatz zu diesen Ergebnissen berichteten Kharat und Saatcioglu nicht nur über eine Reduktion der induzierten CYP1A1-Genexpression durch Estradiol, sondern konnten auch eine durch Estradiol und den ER verstärkte Abschwächung der TCDDinduzierten AhR-Aktivität am CYP1A1-Promotor zeigen (Kharat und Saatcioglu 1996). Beischlag und Perdew wiesen eine abgeschwächte Induzierbarkeit der CYP1A1Genexpression durch Estradiol auch unter Cycloheximid nach, welches die Translation an den Ribosomen hemmt. Ein posttranskriptioneller Wirkmechanismus wurde hierdurch ausgeschlossen. Zusätzlich wurde auch die direkte Bindung eines ligandengebundenen ER $\alpha$ mit dem AhR/ARNT-Rezeptorkomplex dargestellt, so dass Estradiol mit ER $\alpha$ als „transkriptioneller Corepressor“ fungieren könnte (Beischlag und Perdew 2005). Matthews et al. berichteten über eine Verstärkung der TCDD-induzierten CYP1A1-Promotoraktivität durch Bindung an den ERa, welches durch Estradiol weiter gesteigert werden könne. Die Menge der endogenen CYP1A1-mRNA bliebe jedoch unbeeinflusst (Matthews et al. 2005; Matthews und Gustafsson 2006).

\subsubsection{Auswirkung auf die Genexpression von AhR und ARNT}

Die Inkubation der H4IIE-Zellkultur mit dem exogenen AhR-Liganden 3MC in der Konzentration $1 * 10^{-6} \mathrm{M}$ erhöhte die Genexpression von AhR in der RT-PCR nicht signifikant. Eine Tendenz zur Induktion durch 3MC zeigte sich zwar in den entsprechenden Gruppen, es wurde jedoch kein Signifikanzniveau erreicht. Bei Fitzgerald et al. wurde in Hepatomzellen (Hepa-1) durch TCDD ebenso keine Änderung der Genexpression nachgewiesen, in anderen Zelllinien zeigte sich teilweise ein hemmender Einfluss (Fitzgerald et al. 1996). Auch Abbott 
et al. berichteten über eine Hemmung der AhR-Genexpression von Embryonalzellen als Reaktion auf TCDD (Abbott et al. 1994). Möglicherweise handelt es sich hier um eine sehr zellspezifische Reaktion mit feedback-Mechanismus auf die Ligandenbindung durch den AhR.

Auch bezüglich des AhR-Dimerisierungspartners ARNT konnte in keiner der Gruppen eine signifikante Änderung der Genexpression in der RT-PCR nachgewiesen werden, weder durch 3MC, Estradiol oder 4MBC allein noch in Kombination. Auch bei Jana et al. hatte der AhRLigand TCDD keinen Einfluss auf die Genexpression von AhR und ARNT in verschiedenen Zellkulturen (Jana et al. 2000).

\subsection{Auswirkungen von 3MC, Estradiol und 4MBC im Tierversuch}

\subsubsection{Gewicht und Serumparameter}

Die orale Behandlung der männlichen Mäuse über 3 Tage hatte keinen signifikanten Einfluss auf das Körpergewicht der Tiere unabhängig von der Behandlungsgruppe. Für einen signifikanten Gewichtsverlust in den mit 3MC behandelten Gruppen war demnach die Dosis zu niedrig bezüglich des beschriebenen präletalen Gewichtsverlusts bei akuter Toxizität (Poland und Knutson 1982). Eine Beeinflussung der Parameter durch 3MC im Sinne einer chronischen Exposition ist bei der Behandlung über 3 Tage nicht zu erwarten gewesen. Seidlová-Wuttke et al. konnten bei einer dreimonatigen Behandlung von ovarektomierten Ratten eine reduzierte Gewichtszunahme sowohl durch Estradiol als auch durch 4MBC beobachten (Seidlová-Wuttke et al. 2006a). In dem vorliegenden Versuch zeigte sich bei vergleichsweise sehr kurzer Behandlungszeit kein Einfluss durch diese Substanzen auf das Körpergewicht.

Auch das relative Lebergewicht unterschied sich in den Behandlungsgruppen nicht signifikant von der Kontrollgruppe mit Ausnahme in der Gruppe der parallelen Behandlung mit 3MC und 4MBC. Hier zeigte sich eine 15\%ige Reduktion des relativen Lebergewichts, obwohl in den dazugehörigen Gruppen der Einzelbehandlung mit 3MC bzw. 4MBC keine Unterschiede erkennbar waren.

Eine ausreichende orale Bioverfügbarkeit des applizierten Estradiols wird durch die Ergebnisse der Serumanalyse belegt. Im Radioimmunoassay zeigte die mittlere Serumkonzentration von Estradiol bei den E2-behandelten Tieren von 646 pg/ml, verglichen mit den 
$427 \mathrm{pg} / \mathrm{ml}$ in der Kombinationsgruppe, keinen signifikanten Unterschied. Die niedrigen Serumkonzentrationen der anderen Behandlungsgruppen sowie die der Kontrollgruppe konnten im verwendeten Assay nicht dargestellt werden. Die männlichen Wildtypmäuse ähnlichen Alters bei Fisher et al. wiesen eine Serumkonzentration von Estradiol bei 2-5 pg/ml auf (Fisher et al. 1998).

\subsubsection{Auswirkung auf die hepatische Genexpression}

Die Induktion des AhR-Signalweges sollte - analog zu den Versuchen in der Zellkultur anhand der Genexpression des CYP1A1-Enzyms als Endpunkt dieses Signalweges analysiert werden. Es zeigte sich nach der 3-tägigen Behandlung im Lebergewebe den Erwartungen entsprechend eine 1000fach erhöhte Genexpression des CYP1A1 durch den AhR-Liganden 3MC. Die Genexpression der Kombinationsgruppen mit Estradiol und 4MBC wiesen sogar eine noch höhere Enzyminduktion als 3MC allein auf, wobei kein Sigifikanzniveau erreicht wurde.

Wie schon in der Zellkultur-Genexpression, konnte auch in diesem Versuch eine Hemmung der 3MC-verursachten Induktion des CYP1A1 - entsprechend den Ergebnissen des ERODAssays in der Zellkultur - nicht bestätigt werden. Dagegen berichteten Sarkar et al. über eine Verstärkung der TCDD-induzierten CYP1A1-Genexpression durch Estradiol und dies in einer sehr viel geringeren Dosierung mit $5 \mu \mathrm{g} / \mathrm{kg}$ KG als in diesem Versuchsaufbau (600 $\mu \mathrm{g} / \mathrm{kgKG}$ ) (Sarkar et al. 2000). Eine Einbeziehung von Estradiol in die CYP1A1-Aktivierung neben dem TCDD-AhR-Komplex wird aus diesem Grund diskutiert. Unter dieser Annahme müsste sich die AhR-Expression durch Estradiol zudem erhöhen, was sich in den in dieser Arbeit durchgeführten Untersuchungen nicht zeigte. Die Genexpressionen des AhR sowie dessen Dimerisierungspartners ARNT wurden durch 3MC, Estradiol sowie 4MBC einzeln und in Kombination nicht signifikant beeinflusst. Eine Ausnahme bildete die Kombination 4MBC/3MC. Die Genexpression des ARNT wurde durch die Behandlung um 38\% gesteigert. Bezüglich einer diskutierten Kompetition des AhR und ER $\alpha$ um den gemeinsamen Koaktivator ARNT (Safe und Wormke 2003) scheint dieser Zustand nicht zu einer Verstärkung von dessen Genexpression zu führen, wenn eine erhöhte Ligandenbindung durch 3MC an den AhR bzw. Estradiol an den ER $\alpha$ stattfindet.

Konträr zu den Erwartungen einer möglichen Regulierung der ER $\alpha$-Expression durch seinen Liganden Estradiol wurde die hepatische Genexpression von ER $\alpha$ durch keine Behandlung signifikant verändert. Auch die Behandlung mit 3MC zeigte keinen Einfluss auf die ER $\alpha$ - 
Expression, so dass ein antiestrogener Effekt des AhR-Liganden wohl nicht durch eine gehemmte Transkription, sondern eher durch die beschriebene Degradation von vorhandenem ER $\alpha$ verursacht wird (Wormke et al. 2003). Passend hierzu konnten Kharat und Saatcioglu ebenso keine Änderung der ER-Expression durch TCDD in MCF-7-Zellen nachweisen (Kharat und Saatcioglu 1996).

\subsection{Effekte auf die CYP1A1-Aktivität des EROD-Assays im}

\section{Zellhomogenat}

Um die bisher erläuterten Versuchsergebnisse besser erklären zu können, wurde nachfolgend der EROD-Assay mit Zellhomogenat von H4IIE-Kulturen durchgeführt. Um die Beeinflussung der Aktivität des CYP1A1-Enzyms im EROD-Assay messbar zu machen, wurde die CYP1A1-Aktivität in den Zellen vor der Homogenatgewinnung mittels 3MCBehandlung induziert. Erst kurz vor Durchführung des EROD-Assays wurde das gewonnene Homogenat mit den verschiedenen Substanzen versetzt. Da es sich beim Zellhomogenat nur noch um Zellfragmente mit gebundenen Enzymen handelt, konnten durch diese Methode transkriptionelle und posttranskriptionelle Prozesse in der intakten Zelle als Ursache der beobachteten Effekte ausgeschlossen werden.

\subsubsection{Einfluss von 3MC}

In dem unter 4.1.1 beschriebenen EROD-Assay an der intakten Zellkultur zeigte sich ein paradoxer Effekt des CYP1A1-Induktors 3MC in Konzentrationen über $1 * 10^{-6} \mathrm{M}$, da die CYP1A1-Aktivität entgegen einer Dosis-Wirkungs-Beziehung nicht weiter anstieg, sondern sich nicht mehr von der Basalaktivität unterschied. Aufgrund ähnlicher Beobachtungen dieses Effekts in anderen Studien wurde eine direkte Hemmung des CYP1A1-Enzyms durch 3MC vermutet. Dies konnte anhand der Ergebnisse des EROD-Assays am Zellhomogenat eindrücklich bestätigt werden, denn bereits ab einer Konzentration von $1 * 10^{-8} \mathrm{M}$ reduzierte der Zusatz von 3MC die gemessene EROD-Aktivität deutlich und dosisabhängig, sogar um $94 \%$ bei einer Konzentration von $1 * 10^{-5} \mathrm{M}$. Dass es sich hierbei ausschließlich um eine kompetitive Hemmung zwischen dem Induktor 3MC und dem Testsubstrat 7-Ethoxyresorufin um das CYP1A1-Enzym in der EROD-Reaktion handelt - welches zu einem reduzierten Resorufinzeitprodukt führt und mit einer reduzierten CYP1A1-Aktivität gleichgesetzt wird konnten Petrulis und Bunce überzeugend darstellen (Petrulis und Bunce 1999). Passend hierzu wurde eine dosisabhängige weiterhin erhöhte CYP1A1-Genexpression auch in höheren 
Dosierungen unterschiedlichster AhR-Liganden beschrieben. Auch Besselink et al. fanden eine fast äquivalente Affinität vom 7-Ethoxyresorufin und getesteter PCBs zum CYP1A1Enzym (Besselink et al. 1998). Dabei ist die Potenz der kompetitiven Hemmung auch abhängig von der Molekülstruktur des eingesetzten AhR-Liganden (Gooch et al. 1989). Da TCDD im Gegensatz zu anderen AhR-Liganden vom CYP1A1-Enzym nicht metabolisiert werden kann, wird die beschriebene Hemmung der EROD-Aktivität bei TCDD nicht beobachtet (Verhallen et al. 1997). Dass der eingesetzte AhR-Ligand und CYP1A1-Induktor im Gegensatz zu früheren Annahmen in der Testsuspension weiterhin vorhanden ist, konnte sowohl für in-vivo- als auch hier in in-vitro-Versuchen gezeigt werden (Petrulis und Bunce 1999).

\subsubsection{Einfluss von Estradiol und 4MBC}

Anders als in einigen, unter 4.1.2 genannten, Studien waren die Ergebnisse in dieser Arbeit bezüglich eines Einflusses von Estradiol auf die induzierte CYP1A1-Aktivität im ERODAssay und in der Genexpression nicht übereinstimmend. Im EROD-Assay zeigte sich eine reduzierte EROD-Aktivität, wohingegen die Genexpression des CYP1A1-Enzyms durch die Koinkubation mit Estradiol unbeeinflusst blieb. Um Hinweise auf einen direkten Effekt von Estradiol auf die CYP1A1-Aktivität innerhalb der EROD-Assay-Reaktion zu erhalten, wurde dieser mit dem H4IIE-Zellhomogenat durchgeführt. Hier zeigte sich eine streng dosisabhängige Hemmung der CYP1A1-Aktivität durch Estradiol bereits ab einer Konzentration von $1 * 10^{-6} \mathrm{M}$. Fast gänzlich übereinstimmend wirkte sich der Zusatz von 4MBC in denselben Konzentrationen ebenso hemmend auf die Enzymaktivität im ERODAssay aus, obwohl das Xenoöstrogen eine wesentlich niedrigere estrogene Potenz aufweist. Entsprechend den Ergebnissen aus 4.1.1 ist auch bei diesem Effekt von einer kompetitiven Hemmung von Estradiol bzw. 4MBC und 7-Ethoxyresorufin um das CYP1A1-Enzym auszugehen, welches zu einer vermeintlichen Hemmung des Enzyms führt, da weniger Resorufin pro Zeiteinheit gebildet wird.

Dass das CYP1A1-Enzym für die oxidative Metabolisierung von Estradiol mitverantwortlich ist, ist schon seit längerem bekannt. Lee et al. konnten zudem eine besonders hohe Aktivität für die 2-Hydroxylierung nachweisen (Lee AJ et al. 2003). Spink et al. wiesen eine erhöhte Metabolisierungsrate von Estradiol in einer Zellkultur nach, die zuvor mit TCDD behandelt wurde (Spink et al. 1990). Interessanterweise konnte dabei auch eine 86\%ige Hemmung der CYP1A1-bedingten Hydroxylierung von Estradiol durch das spezifische Substrat 7- 
Ethoxyresorufin gezeigt werden (Spink et al. 1992), welches ebenso klar auf eine kompetitive Hemmung hinweist. Dass es sich bei dem mit 4MBC versetzten Zellhomogenat um denselben Effekt im EROD-Assay handelt, deuten die Untersuchungen von Völkel et al an. Hier wurden die Metaboliten des 4MBCs nach oraler Aufnahme von Ratten untersucht, welche auf eine sehr hohe Biotransformation durch oxidierende CYP450-Enzyme hindeuten (Völkel et al. 2006).

\subsubsection{Einfluss von estrogenen Stoffen sowie anderen Substanzen}

Aus der Beobachtung heraus, dass auch 4MBC kompetitiv als Substrat für das CYP1A1Enzym im EROD-Assay fungieren konnte, sollte anschließend untersucht werden, welche estrogenen Stoffe und bekannte ER-Liganden ebenso diesen Effekt (jeweils bei einer Konzentration von $1 * 10^{-5} \mathrm{M}$ ) verursachten. Hierzu gehören u.a. auch das Phytoöstrogen Genistein, der selektive Estrogenrezeptormodulator (SERM) Raloxifen sowie auch der Estrogenrezeptorantagonist ICI. Zusätzlich wurden auch die anderen Steroidhormone Progesteron, Testosteron und Corticosteron auf deren Einfluss im EROD-Assay getestet.

Bei den estrogenen Substanzen zeigte sich besonders bei dem Estrogen Estron eine Hemmung des CYP1A1-Enzyms auf 58\%, wohingegen bei dem Stoffwechselprodukt Estriol kein signifikanter Einfluss auftrat und beim Stereoisomer 17 $\alpha$-Estradiol die gemessene CYP1A1Aktivität auf 84\% sank. Diese Ergebnisse aus dem EROD-Assay an der vitalen Zellinie unter 4.1.3 zeigten ein sehr ähnliches Bild. Lediglich bezüglich des Estriols stimmten die Ergebnisse nicht überein, da sich im EROD-Assay im Homogenat eine Hemmung des Enzyms nicht wie erwartet nachweisen ließ. Auch Klinger et al. konnten für das $17 \alpha$ - und $17 \beta$-Estradiol in der Konzentration von $1 * 10^{-5} \mathrm{M}$ eine Hemmung der EROD-Aktivität bei dem Zusatz zu Mikrosomen um 82\% bzw. 61\% feststellen. Estron verringerte die Aktivität bei den geschilderten Versuchen um 38\%, Estriol um 11\% (Klinger et al. 2002), was eine klare Abhängigkeit von der Molekülstruktur für die Fähigkeit der eingesetzten Substanz vom CYP1A1-Enzym gebunden zu werden unterstützt.

Im Gegensatz zu den in dieser Arbeit akquirierten Ergebnissen, wo keines der anderen Steroidhormone einen Effekt auf die EROD-Aktivität zeigte, konnten Klinger et al. eine Hemmung der Aktivität durch $1 * 10^{-5} \mathrm{M}$ Testosteron um 34\% nachweisen (Klinger et al. 2002). 
Das Phytoöstrogen Genistein verfügte als Zugabe im EROD-Assay über eine starke inhibitorische Potenz gegenüber dem CYP1A1-Enzym, so dass die gebildete Resorufinmenge auf $31 \%$ gegenüber der Kontrolle gesenkt wurde, wohingegen im EROD-Assay an der lebenden Zellkultur kein Einfluss auf die induzierte EROD-Aktivität nachgewiesen werden konnte. Hier hatte sich jedoch auch eine signifikante Induktion des CYP1A1 durch Genistein allein herausgestellt, weshalb sich beide Effekte möglicherweise aufheben. Dies würde die Ergebnisse von Shertzer et al. bestätigen, welche ebenso eine erhöhte CYP1A1-Aktivität nach Behandlung mit Genistein allein beobachteten, aber im Mikrosomen-Assay eine starke nichtkompetitive Inhibition des CYP1A1-Enzyms nachweisen konnten (Shertzer et al. 1999).

Raloxifen besitzt ebenso ein signifikantes Potential für eine Hemmung der EROD-Aktivität, obwohl der Metabolisierungsweg hauptsächlich über Glukuronidierung verläuft und nicht wie bei den Estrogenen - über Oxidation durch CYP450-Enzyme (Hochner-Celnikier 1999; Kemp et al. 2002).

Der ER-Antagonist ICI zeigte in dieser Arbeit keine eigene Funktion als Substrat für das CYP1A1-Enzym im EROD-Assay. Dies stimmt überein mit den Ergebnissen aus dem ERODAssay der Zellkultur, wo für hinzugefügtes ICI kein Effekt nachgewiesen werden konnte. Im Gegensatz dazu berichteten Gräns et al. über die Substanz als potenten Inhibitor des CYP1A1-Enzyms (Grans et al. 2010). Möglicherweise spielt hierbei der unterschiedliche Ursprung der Lebermikrosomen eine entscheidende Rolle (Rattenhepatomzellen vs. Primärzellkultur aus Fischen).

\subsection{Bewertung und Methodenkritik}

In der dargestellten Arbeit sollte eine AhR-ER $\alpha$-Interaktion im Hinblick auf die Wirkung von Estradiol und 4MBC auf den AhR-Signalweg mit Hilfe des EROD-Assays sowie der Messung der dazugehörigen Genexpression in vitro und in vivo untersucht werden. Die hier erlangten Ergebnisse zeigten keinen Einfluss von Estradiol oder 4MBC auf die AhRSignalkaskade, aber auf die Enzymaktivität des Endproduktes CYP1A1 selbst. Eine Aussage bezüglich einer AhR-ER $\alpha$-Interaktion ist hiermit nicht möglich. Es konnte jedoch in dieser Arbeit sehr deutlich ein bedeutender Störfaktor beim Gebrauch des EROD-Assays als Testmethode nachgewiesen und näher eingegrenzt werden, der zwar bekannt war (Petrulis und Bunce 1999), zuvor aber nur sehr gering bzw. auch in den zitierten Studien vielfach überhaupt nicht beachtet wurde: Es handelt sich um die kompetitive Inhibition des CYP1A1- 
Enzyms im EROD-Assay durch Induktoren wie 3MC sowie auch durch Estrogen und estrogenähnliche Substanzen. Da der EROD-Assay weiterhin als weltweit günstige und schnell durchführbare Testmethode verwendet wird, um eine Exposition gegenüber TCDD und dioxinähnlichen Substanzen nachzuweisen (Hestermann et al. 2000), besteht hierin eine besondere Gefahr der Unterschätzung und Akquirierung von falsch negativen Ergebnissen bei der Untersuchung von Umwelt- bzw. Nahrungsmittelproben. Bereits Petrulis und Bunce forderten eine vorherige Untersuchung des zu untersuchenden Stoffes auf seine kompetitiven Eigenschaften im EROD-Assay bevor eine Einschätzung auf sein Gefährdungspotential getroffen werden könne, da diese sehr häufig auf den Ergebnissen des Assays im Vergleich zu TCDD beruhe. Insbesondere eine in der Umwelt häufig anzutreffende Mischung aus verschiedenen AhR-Induktoren führt im EROD-Assay zu einer ernstzunehmenden Unterschätzung des Gefährdungspotentials (Petrulis und Bunce 1999; Petrulis et al. 2001). In dieser Arbeit konnte eindeutig gezeigt werden, dass auch der Zusatz von Estrogen sowie estrogenähnlichen Substanzen die Ergebnisse des EROD-Assays in erheblichem Maße beeinflusst. Für das Xenoöstrogen 4MBC konnte dies erstmalig nachgewiesen werden. Dass das inzwischen gehäuft in den Abwässern befindliche synthetische $17 \alpha$-Ethinylestradiol aus oralen Kontrazeptiva die CYP1A1-Aktivität im EROD-Assay hemmt, konnte ebenso bereits aufgezeigt werden (Kirby et al. 2007; Grans et al. 2010). Eine genaue Kenntnis dieser Störfaktoren erscheint bei zunehmender Belastung der Umwelt mit bioaktiven Stoffen beispielsweise aus Medikamenten somit abschließend unabdingbar bei der Verwendung des EROD-Assays als Screeningtest für Umweltchemikalien. 


\section{$5 \quad$ Zusammenfassung}

Im Zuge der zahlreichen Studien bezüglich der gesundheitlichen Auswirkungen von Umweltchemikalien und insbesondere endokrinen Disruptoren auf den Menschen wurden unterschiedliche Mechanismen einer Interaktion vom ER $\alpha$ - und AhR-Signalweg im Sinne eines „AhR-ER $\alpha$ crosstalks“ diskutiert. Ein möglicher Einfluss von Estrogen auf die AhRSignalkaskade wurde, im Gegensatz zu den Auswirkungen von ED auf den ER-Signalweg, kaum untersucht. Die vorhandenen Studien deuteten auf eine inhibitorische Wirkung von Estradiol auf die durch Dioxin induzierte CYP1A1-Aktivität und damit auf einen direkten Einfluss auf die AhR-Signalkaskade hin. Diese Beobachtungen wurden in dieser Arbeit näher überprüft:

- Im weit verbreiteten EROD-Assay zeigte sowohl Estradiol als auch das in Sonnenschutzmitteln enthaltene Xenoöstrogen 4MBC eine signifikante und deutlich dosisabhängige Inhibierung der induzierten CYP1A1-Enzymaktivität einer H4IIEZellkultur. Auch für estrogenähnliche Substanzen konnte dieser Effekt nachgewiesen werden, welcher durch Zugabe des Estrogenrezeptor-Antagonisten ICI nicht verhindert wurde. Der verwendete CYP1A1-Induktor und AhR-Modellligand 3MC allein führte konträr zu den Erwartungen in höheren Dosierungen zu keiner signifikanten Änderung der Enzymaktivität.

- In der mit 3MC, Estradiol und 4MBC behandelten H4IIE-Zellkultur konnte der im EROD-Assay beobachtete Effekt in der Genexpression von CYP1A1 nicht nachgewiesen werden. Auch die Genexpression von AhR und seinem Dimerisierungspartner ARNT wurde nicht verändert.

- In einem Tierversuch mit männlichen Wildtyp-Mäusen hatte die orale Applikation von Estradiol und 4MBC über 3 Tage keinen Einfluss auf die durch 3MC induzierte CYP1A1Genexpression. Die Genexpression von AhR und ARNT blieb ebenfalls konstant.

- An Zellhomogenat aus der H4IIE-Zellkultur mit 3MC induziertem CYP1A1-Enzym konnten die zuvor im EROD-Assay nachgewiesenen hemmenden Effekte auf die CYP1A1-Aktivität durch Estradiol, 4MBC und 3MC überdeutlich und dosisabhängig dargestellt werden. Auch Estron, 17 $\alpha$-Estradiol, Genistein und Raloxifen wiesen eine inhibitorische Wirkung auf.

Die durch Estradiol, 4MBC und estrogenähnliche Substanzen reduzierte EROD-Aktivität in der Zellkultur stellte sich durch die Durchführung im Zellhomogenat als Resultat einer 
kompetitiven Inhibition des CYP1A1-Enzyms und damit als gravierender Störfaktor im EROD-Assay heraus. Auch der verwendete Induktor 3MC fungierte durch die mögliche Metabolisierung durch CYP1A1 als kompetitives Substrat in höheren Dosierungen. Eine inhibitiorische Wirkung von Estradiol oder 4MBC auf die CYP1A1-Genexpression mittels Einfluss auf den AhR-Signalweg konnte in dieser Arbeit nicht nachgewiesen werden. Damit muss die weitläufig praktizierte und vom Testsystem vorgesehene Gleichsetzung von Veränderungen der EROD-Aktivität mit der CYP1A1-Genexpression in Frage gestellt werden. Die deutlichen Auswirkungen des Störfaktors der kompetitiven Inhibition des CYP1A1-Enzyms im EROD-Assay durch die beschriebenen, durch CYP1A1 metabolisierbaren, Stoffe können als Mitverursacher konträrer Studienergebnisse angesehen werden. Desweiteren kann die Unkenntnis dieser Störfaktoren im EROD-Assay zu einer ernstzunehmenden Unterschätzung des Gefährdungspotentials von Umweltchemikalien führen, besonders im Hinblick auf die zunehmende Belastung der Umwelt durch Gemische von bioaktiven Stoffen wie beispielsweise hormonell aktiven Medikamenten. 


\section{$6 \quad$ Literatur}

Literaturverzeichnis

Abbott BD, Perdew GH, Birnbaum LS (1994): Ah receptor in embryonic mouse palate and effects of TCDD on receptor expression. Toxicol Appl Pharmacol 126 (1): 16-25

Ahlborg UG, Brouwer A, Fingerhut MA, Jacobson JL, Jacobson SW, Kennedy SW, Kettrup AA, Koeman JH, Poiger H, Rappe C et al. (1992): Impact of polychlorinated dibenzo-p-dioxins, dibenzofurans, and biphenyls on human and environmental health, with special emphasis on application of the toxic equivalency factor concept. Eur J Pharmacol 228 (4): 179-199

Alavanja MC, Samanic C, Dosemeci M, Lubin J, Tarone R, Lynch CF, Knott C, Thomas K, Hoppin JA, Barker J et al. (2003): Use of agricultural pesticides and prostate cancer risk in the Agricultural Health Study cohort. Am J Epidemiol 157 (9): 800814

Baskin LS, Himes K, Colborn T (2001): Hypospadias and endocrine disruption: is there a connection? Environ Health Perspect 109 (11): 1175-1183

Batzler W, Giersiepen K, Hentschel S, Husmann G, Kaatsch P, Katalinic A, Kieschke J, Kraywinkel K, Meyer M, Stabenow R et al.: Krebs in Deutschland 2003 - 2004. Häufigkeiten und Trends 6. überarbeitete Auflage. Robert Koch-Institut (Hrsg) und die Gesellschaft der epidemiologischen Krebsregister in Deutschland e. V. (Hrsg). Berlin 2008

Beischlag TV, Perdew GH (2005): ER alpha-AHR-ARNT protein-protein interactions mediate estradiol-dependent transrepression of dioxin-inducible gene transcription. J Biol Chem 280 (22): 21607-21611

Beischlag TV, Luis Morales J, Hollingshead BD, Perdew GH (2008): The aryl hydrocarbon receptor complex and the control of gene expression. Crit Rev Eukaryot Gene Expr 18 (3): 207-250

Benedict WF, Gielen JE, Owens IS, Niwa A, Bebert DW (1973): Aryl hydrocarbon hydroxylase induction in mammalian liver cell culture. IV. Stimulation of the enzyme activity in established cell lines derived from rat or mouse hepatoma and from normal rat liver. Biochem Pharmacol 22 (21): 2766-2769

Bertazzi PA, Bernucci I, Brambilla G, Consonni D, Pesatori AC (1998): The Seveso studies on early and long-term effects of dioxin exposure: a review. Environ Health Perspect 106 Suppl 2 625-633

Besselink HT, Denison MS, Hahn ME, Karchner SI, Vethaak AD, Koeman JH, Brouwer A (1998): Low inducibility of CYP1A activity by polychlorinated biphenyls (PCBs) in flounder (Platichthys flesus): characterization of the Ah receptor and the role of CYP1A inhibition. Toxicol Sci 43 (2): 161-171

Bigby M (1999): The sunscreen and melanoma controversy. Arch Dermatol 135 (12): 15261527 
Bradford MM (1976): A rapid and sensitive method for the quantitation of microgram quantities of protein utilizing the principle of protein-dye binding. Anal Biochem $\underline{72} 248-254$

Broccardo CJ, Billings RE, Chubb LS, Andersen ME, Hanneman WH (2004): Single cell analysis of switch-like induction of CYP1A1 in liver cell lines. Toxicol Sci 78 (2): 287-294

Brucker-Davis F (1998): Effects of environmental synthetic chemicals on thyroid function. Thyroid 8 (9): 827-856

Bruhn T, Gülden M, Ludewig S, Seibert H: Einstufung von Schadstoffen als endokrin wirksame Substanzen, UBA-Texte 65/99, hrsg. v. Umweltbundesamt 1999

Burke MD, Mayer RT (1974): Ethoxyresorufin: direct fluorimetric assay of a microsomal Odealkylation which is preferentially inducible by 3-methylcholanthrene. Drug Metab Dispos 2 (6): 583-588

Burke S (2001): Missing Values, Outliers, Robust Statistics \& Non-parametric Methods. LCGC Europe Online Supplement 19-24

Carlsen E, Giwercman A, Keiding N, Skakkebaek NE (1992): Evidence for decreasing quality of semen during past 50 years. BMJ 305 (6854): 609-613

Carver LA, Hogenesch JB, Bradfield CA (1994): Tissue specific expression of the rat Ahreceptor and ARNT mRNAs. Nucleic Acids Res 22 (15): 3038-3044

Cenni B, Picard D (1999): Ligand-independent Activation of Steroid Receptors: New Roles for Old Players. Trends Endocrinol Metab 10 (2): 41-46

Cheskis BJ, Greger JG, Nagpal S, Freedman LP (2007): Signaling by estrogens. J Cell Physiol 213 (3): 610-617

Clemons JH, Dixon DG, Bols NC (1997): Derivation of 2,3,7,8-TCDD toxic equivalent factors (TEFs) for selected dioxins, furans and PCBs with rainbow trout and rat liver cell lines and the influence of exposure time. Chemosphere 34 (5-7): 11051119

Cohn BA, Wolff MS, Cirillo PM, Sholtz RI (2007): DDT and breast cancer in young women: new data on the significance of age at exposure. Environ Health Perspect $\underline{115}$ (10): 1406-1414

Colborn T, vom Saal FS, Soto AM (1993): Developmental effects of endocrine-disrupting chemicals in wildlife and humans. Environ Health Perspect 101 (5): 378-384

Colborn T, Dumanoski D, Myers JP: Our Stolen Future: Are We Threatening Our Fertility, Intelligence, and Survival? A Scientific Detective Story. Dutton, New York 1996

Couse JF, Korach KS (1999): Estrogen receptor null mice: what have we learned and where will they lead us? Endocr Rev 20 (3): 358-417 
Daxenberger A (2002): Pollutants with androgen-disrupting potency. Eur J Lipid Sci Technol $104(2): 124-130$

Denison MS, Pandini A, Nagy SR, Baldwin EP, Bonati L (2002): Ligand binding and activation of the Ah receptor. Chem Biol Interact 141 (1-2): 3-24

Diamanti-Kandarakis E, Bourguignon JP, Giudice LC, Hauser R, Prins GS, Soto AM, Zoeller RT, Gore AC (2009): Endocrine-disrupting chemicals: an Endocrine Society scientific statement. Endocr Rev 30 (4): 293-342

Elsner P, Hölzle E, Diepgen T, Grether-Beck S, Hönigsmann H, Krutmann J, ScharffetterKochanek K, Schwarz T, Luger T (2006): Täglicher Lichtschutz in der Prävention chronischer UV-Schäden der Haut. Leitlinie der Deutschen Gesellschaft für Dermatologie

Enmark E, Pelto-Huikko M, Grandien K, Lagercrantz S, Lagercrantz J, Fried G, Nordenskjold M, Gustafsson JA (1997): Human estrogen receptor beta-gene structure, chromosomal localization, and expression pattern. J Clin Endocrinol Metab $\underline{82}$ (12): 4258-4265

Evans RM (1988): The steroid and thyroid hormone receptor superfamily. Science $\underline{240}$ (4854): 889-895

Fernandez-Salguero PM, Pineau T, Hilbert DM, McPhail T, Lee SS, Kimura S, Nebert DW, Rudikoff S, Ward JM, Gonzalez FJ (1995): Immune system impairment and hepatic fibrosis in mice lacking the dioxin-binding Ah receptor. Science $\underline{268}$ (5211): 722-726

Fernandez-Salguero PM, Hilbert DM, Rudikoff S, Ward JM, Gonzalez FJ (1996): Arylhydrocarbon receptor-deficient mice are resistant to 2,3,7,8-tetrachlorodibenzo-pdioxin-induced toxicity. Toxicol Appl Pharmacol 140 (1): 173-179

Fisher CR, Graves KH, Parlow AF, Simpson ER (1998): Characterization of mice deficient in aromatase (ArKO) because of targeted disruption of the cyp19 gene. Proc Natl Acad Sci U S A 95 (12): 6965-6970

FitzGerald CT, Fernandez-Salguero P, Gonzalez FJ, Nebert DW, Puga A (1996): Differential regulation of mouse Ah receptor gene expression in cell lines of different tissue origins. Arch Biochem Biophys 333 (1): 170-178

Gasparro FP, Mitchnick M, Nash JF (1998): A review of sunscreen safety and efficacy. Photochem Photobiol 68 (3): 243-256

Gefeller O, Pfahlberg A (2002): Sunscreen use and melanoma: a case of evidence-based prevention? Photodermatol Photoimmunol Photomed 18 (3): 153-156; discussion 156

Gooch JW, Elskus AA, Kloepper-Sams PJ, Hahn ME, Stegeman JJ (1989): Effects of orthoand non-ortho-substituted polychlorinated biphenyl congeners on the hepatic monooxygenase system in scup (Stenotomus chrysops). Toxicol Appl Pharmacol

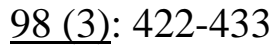


Gore AC (2001): Environmental toxicant effects on neuroendocrine function. Endocrine 14 (2): 235-246

Grans J, Wassmur B, Celander MC (2010): One-way inhibiting cross-talk between arylhydrocarbon receptor (AhR) and estrogen receptor (ER) signaling in primary cultures of rainbow trout hepatocytes. Aquat Toxicol 100 (3): 263-270

Green A, Williams G, Neale R, Hart V, Leslie D, Parsons P, Marks GC, Gaffney P, Battistutta $\mathrm{D}$, Frost $\mathrm{C}$ et al. (1999): Daily sunscreen application and betacarotene supplementation in prevention of basal-cell and squamous-cell carcinomas of the skin: a randomised controlled trial. Lancet 354 (9180): 723-729

Green S, Walter P, Greene G, Krust A, Goffin C, Jensen E, Scrace G, Waterfield M, Chambon P (1986): Cloning of the human oestrogen receptor cDNA. J Steroid Biochem 24 (1): 77-83

Grier JW (1982): Ban of DDT and subsequent recovery of Reproduction in bald eagles. Science 218 (4578): 1232-1235

Gronemeyer H, Gustafsson JA, Laudet V (2004): Principles for modulation of the nuclear receptor superfamily. Nat Rev Drug Discov 3 (11): 950-964

Grun F, Blumberg B (2006): Environmental obesogens: organotins and endocrine disruption via nuclear receptor signaling. Endocrinology 147 (6 Suppl): S50-55.

Gülden M, Turan A, Seibert H: Substanzen mit endokriner Wirkung in Oberflächengewässern, UBA-Texte 46/97, hrsg. v. Umweltbundesamt 1997

Guillette LJ, Jr., Gross TS, Masson GR, Matter JM, Percival HF, Woodward AR (1994): Developmental abnormalities of the gonad and abnormal sex hormone concentrations in juvenile alligators from contaminated and control lakes in Florida. Environ Health Perspect 102 (8): 680-688

Guo YL, Hsu PC, Hsu CC, Lambert GH (2000): Semen quality after prenatal exposure to polychlorinated biphenyls and dibenzofurans. Lancet 356 (9237): 1240-1241

Hahn ME, Lamb TM, Schultz ME, Smolowitz RM, Stegeman JJ (1993): Cytochrome P4501A induction and inhibition by 3,3',4,4'-tetrachlorobiphenyl in an Ah receptorcontaining fish hepatoma cell line (PLHC-1). Aquatic Toxicology 26 185208

Hall JM, Couse JF, Korach KS (2001): The multifaceted mechanisms of estradiol and estrogen receptor signaling. J Biol Chem 276 (40): 36869-36872

Hany J, Nagel R (1995): Nachweis von UV-Filtersubstanzen in Muttermilch. Deutsche Lebensmittel-Rundschau 91: 341-345

Heid CA, Stevens J, Livak KJ, Williams PM (1996): Real time quantitative PCR. Genome Res 6 (10): 986-994

Heid SE, Pollenz RS, Swanson HI (2000): Role of heat shock protein 90 dissociation in mediating agonist-induced activation of the aryl hydrocarbon receptor. $\mathrm{Mol}$ Pharmacol 57 (1): 82-92 
Henderson BE, Ross R, Bernstein L (1988): Estrogens as a cause of human cancer: the Richard and Hinda Rosenthal Foundation award lecture. Cancer Res 48 (2): 246253

Herbst AL, Ulfelder H, Poskanzer DC (1971): Adenocarcinoma of the vagina. Association of maternal stilbestrol therapy with tumor appearance in young women. $N$ Engl $J$ Med 284 (15): 878-881

Hestermann EV, Stegeman JJ, Hahn ME (2000): Serum alters the uptake and relative potencies of halogenated aromatic hydrocarbons in cell culture bioassays. Toxicol

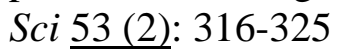

Higuchi R, Dollinger G, Walsh PS, Griffith R (1992): Simultaneous amplification and detection of specific DNA sequences. Biotechnology (N Y) 10 (4): 413-417

Hochner-Celnikier D (1999): Pharmacokinetics of raloxifene and its clinical application. Eur J Obstet Gynecol Reprod Biol 85 (1): 23-29

Hoivik D, Willett K, Wilson C, Safe S (1997): Estrogen does not inhibit 2,3,7, 8tetrachlorodibenzo-p-dioxin-mediated effects in MCF-7 and Hepa 1c1c7 cells. $J$ Biol Chem 272 (48): 30270-30274

Holland PM, Abramson RD, Watson R, Gelfand DH (1991): Detection of specific polymerase chain reaction product by utilizing the 5'----3' exonuclease activity of Thermus aquaticus DNA polymerase. Proc Natl Acad Sci U S A 88 (16): 7276-7280

Hotchkiss AK, Rider CV, Blystone CR, Wilson VS, Hartig PC, Ankley GT, Foster PM, Gray CL, Gray LE (2008): Fifteen years after "Wingspread"--environmental endocrine disrupters and human and wildlife health: where we are today and where we need to go. Toxicol Sci 105 (2): 235-259

Hoyer AP, Grandjean P, Jorgensen T, Brock JW, Hartvig HB (1998): Organochlorine exposure and risk of breast cancer. Lancet 352 (9143): 1816-1820

Hsu PC, Huang W, Yao WJ, Wu MH, Guo YL, Lambert GH (2003): Sperm changes in men exposed to polychlorinated biphenyls and dibenzofurans. JAMA 289 (22): 29432944

Huyghe E, Matsuda T, Thonneau P (2003): Increasing incidence of testicular cancer worldwide: a review. J Urol 170 (1): 5-11

Ikuta T, Eguchi H, Tachibana T, Yoneda Y, Kawajiri K (1998): Nuclear localization and export signals of the human aryl hydrocarbon receptor. J Biol Chem 273 (5): 2895-2904

Israel DI, Whitlock JP, Jr. (1983): Induction of mRNA specific for cytochrome P1-450 in wild type and variant mouse hepatoma cells. J Biol Chem 258 (17): 10390-10394

Jana NR, Sarkar S, Ishizuka M, Yonemoto J, Tohyama C, Sone H (1999): Cross-talk between 2,3,7,8-tetrachlorodibenzo-p-dioxin and testosterone signal transduction pathways in LNCaP prostate cancer cells. Biochem Biophys Res Commun 256 (3): 462-468 
Jana NR, Sarkar S, Ishizuka M, Yonemoto J, Tohyama C, Sone H (2000): Comparative effects of 2,3,7,8-tetrachlorodibenzo-p-dioxin on MCF-7, RL95-2, and LNCaP cells: role of target steroid hormones in cellular responsiveness to CYP1A1 induction. Mol Cell Biol Res Commun 4 (3): 174-180

Janjua NR, Mogensen B, Andersson AM, Petersen JH, Henriksen M, Skakkebaek NE, Wulf HC (2004): Systemic absorption of the sunscreens benzophenone-3, octylmethoxycinnamate, and 3-(4-methyl-benzylidene) camphor after whole-body topical application and reproductive hormone levels in humans. J Invest Dermatol 123 (1): 57-61

Jensen EV, DeSombre ER (1973): Estrogen-receptor interaction. Science 182 (108): 126-134

Jeong HG, Lee SS (1998): Suppressive effects of estradiol on 2,3,7,8-tetrachlorodibenzo-pdioxin-mediated transcriptional activation of murine Cyp1a-1 in mouse hepatoma Hepa 1c1c7 cells. Cancer Lett 133 (2): 177-184

Katalinic A, Lemmer A, Zawinell A, Rawal R, Waldmann A (2009): Trends in hormone therapy and breast cancer incidence - results from the German Network of Cancer Registries. Pathobiology 76 (2): 90-97

Kato S, Endoh H, et al. (1995): Activation of the estrogen receptor through phosphorylation by mitogen-activated protein kinase. Science 270 (5241): 1491-1494

Kelce WR, Stone CR, Laws SC, Gray LE, Kemppainen JA, Wilson EM (1995): Persistent DDT metabolite p,p'-DDE is a potent androgen receptor antagonist. Nature $\underline{375}$ (6532): 581-585

Kemp DC, Fan PW, Stevens JC (2002): Characterization of raloxifene glucuronidation in vitro: contribution of intestinal metabolism to presystemic clearance. Drug Metab Dispos 30 (6): 694-700

Kennedy SW, Jones SP (1994): Simultaneous measurement of cytochrome P4501A catalytic activity and total protein concentration with a fluorescence plate reader. Anal Biochem 222 (1): 217-223

Kewley RJ, Whitelaw ML, Chapman-Smith A (2004): The mammalian basic helix-loophelix/PAS family of transcriptional regulators. Int J Biochem Cell Biol 36 (2): 189-204

Kharat I, Saatcioglu F (1996): Antiestrogenic effects of 2,3,7,8-tetrachlorodibenzo-p-dioxin are mediated by direct transcriptional interference with the liganded estrogen receptor. Cross-talk between aryl hydrocarbon- and estrogen-mediated signaling. $J$ Biol Chem 271 (18): 10533-10537

Kirby MF, Smith AJ, Rooke J, Neall P, Scott AP, Katsiadaki I (2007): Ethoxyresorufin-Odeethylase (EROD) and vitellogenin (VTG) in flounder (Platichthys flesus): system interaction, crosstalk and implications for monitoring. Aquat Toxicol $\underline{81}$ (3): 233-244 
Klinger W, Lupp A, Karge E, Baumbach H, Eichhorn F, Feix A, Fuldner F, Gernhardt S, Knels L, Kost B et al. (2002): Estradiol, testosterone, dehydroepiandrosterone and androstenedione: novel derivatives and enantiomers. Interactions with rat liver microsomal cytochrome P450 and antioxidant/radical scavenger activities in vitro. Toxicol Lett 128 (1-3): 129-144

Kociba RJ, Keyes DG, et al. (1978): Results of a two-year chronic toxicity and oncogenicity study of 2,3,7,8-tetrachlorodibenzo-p-dioxin in rats. Toxicol Appl Pharmacol $\underline{46}$ (2): 279-303

Kuiper GG, Enmark E, Pelto-Huikko M, Nilsson S, Gustafsson JA (1996): Cloning of a novel receptor expressed in rat prostate and ovary. Proc Natl Acad Sci U S A 93 (12): $5925-5930$

Kuiper GG, Carlsson B, Grandien K, Enmark E, Haggblad J, Nilsson S, Gustafsson JA (1997): Comparison of the ligand binding specificity and transcript tissue distribution of estrogen receptors alpha and beta. Endocrinology 138 (3): 863-870

Kushner PJ, Agard DA, Greene GL, Scanlan TS, Shiau AK, Uht RM, Webb P (2000): Estrogen receptor pathways to AP-1. J Steroid Biochem Mol Biol 74 (5): 311-317

Lai KP, Wong MH, Wong CK (2004): Modulation of AhR-mediated CYP1A1 mRNA and EROD activities by 17beta-estradiol and dexamethasone in TCDD-induced H411E cells. Toxicol Sci 78 (1): 41-49

Lee AJ, Cai MX, Thomas PE, Conney AH, Zhu BT (2003): Characterization of the oxidative metabolites of 17beta-estradiol and estrone formed by 15 selectively expressed human cytochrome p450 isoforms. Endocrinology 144 (8): 3382-3398

Lee SS, Jeong HG, Yang KH (1998): Effects of estradiol and progesterone on cytochrome P4501A1 expression in Hepa 1c1c7 cells. Biochem Mol Biol Int 45 (4): 775-781

Livak KJ, Flood SJ, Marmaro J, Giusti W, Deetz K (1995): Oligonucleotides with fluorescent dyes at opposite ends provide a quenched probe system useful for detecting PCR product and nucleic acid hybridization. PCR Methods Appl 4 (6): 357-362

Lofroth G, Zebuhr Y (1992): Polychlorinated dibenzo-p-dioxins (PCDDs) and dibenzofurans (PCDFs) in mainstream and sidestream cigarette smoke. Bull Environ Contam Toxicol 48 (6): 789-794

Lovekamp-Swan T, Jetten AM, Davis BJ (2003): Dual activation of PPARalpha and PPARgamma by mono-(2-ethylhexyl) phthalate in rat ovarian granulosa cells. Mol Cell Endocrinol 201 (1-2): 133-141

Lubet RA, Nims RW, Mayer RT, Cameron JW, Schechtman LM (1985): Measurement of cytochrome P-450 dependent dealkylation of alkoxyphenoxazones in hepatic S9s and hepatocyte homogenates: effects of dicumarol. Mutat Res 142 (3): 127-131

Mangelsdorf DJ, Thummel C, Beato M, Herrlich P, Schutz G, Umesono K, Blumberg B, Kastner P, Mark M, Chambon P et al. (1995): The nuclear receptor superfamily:

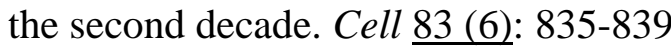


Markey CM, Rubin BS, Soto AM, Sonnenschein C (2002): Endocrine disruptors: from Wingspread to environmental developmental biology. J Steroid Biochem Mol Biol 83 (1-5): 235-244

Markey CM, Soto AM, Sonnenschein C: Environmental Disruptors of Sex Hormone Action. Encyclopedia of Hormones. HL Henry and AW Norman, Elsevier Science, USA 2003

Matthews J, Gustafsson JA (2006): Estrogen receptor and aryl hydrocarbon receptor signaling pathways. Nucl Recept Signal 4 e016

Matthews J, Wihlen B, Thomsen J, Gustafsson JA (2005): Aryl hydrocarbon receptormediated transcription: ligand-dependent recruitment of estrogen receptor alpha to 2,3,7,8-tetrachlorodibenzo-p-dioxin-responsive promoters. Mol Cell Biol 25 (13): 5317-5328

Meyer TE, Coker AL, Sanderson M, Symanski E (2007): A case-control study of farming and prostate cancer in African-American and Caucasian men. Occup Environ Med $\underline{64}$ (3): $155-160$

Miller VM, Duckles SP (2008): Vascular actions of estrogens: functional implications. Pharmacol Rev 60 (2): 210-241

Mitsushima D, Funabashi T, Kimura F (2003): Estrogen increases messenger RNA and immunoreactivity of aryl-hydrocarbon receptor nuclear translocator 2 in the rat mediobasal hypothalamus. Biochem Biophys Res Commun 307 (2): 248-253

Morrison H, Savitz D, Semenciw R, Hulka B, Mao Y, Morison D, Wigle D (1993): Farming and prostate cancer mortality. Am J Epidemiol 137 (3): 270-280

Mueller SO, Kling M, Arifin Firzani P, Mecky A, Duranti E, Shields-Botella J, Delansorne R, Broschard T, Kramer PJ (2003): Activation of estrogen receptor alpha and ERbeta by 4-methylbenzylidene-camphor in human and rat cells: comparison with phytoand xenoestrogens. Toxicol Lett 142 (1-2): 89-101

Mullis KB, Faloona FA (1987): Specific synthesis of DNA in vitro via a polymerasecatalyzed chain reaction. Methods Enzymol 155 335-350

Murphy LC, Dotzlaw H, Leygue E, Douglas D, Coutts A, Watson PH (1997): Estrogen

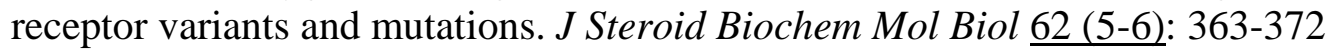

Muto H, Takizawa Y (1989): Dioxins in cigarette smoke. Arch Environ Health 44 (3): 171174

Nagtegaal M, Ternes TA, Baumann W, Nagel R (1997): UV-Filtersubstanzen in Wasser und Fischen. UWSF-2 Umwelchem. Ökotox. 9: 79-86

Newbold RR, Padilla-Banks E, Snyder RJ, Phillips TM, Jefferson WN (2007):

Developmental exposure to endocrine disruptors and the obesity epidemic. Reprod Toxicol 23 (3): 290-296 
Nilsson S, Makela S, Treuter E, Tujague M, Thomsen J, Andersson G, Enmark E, Pettersson K, Warner M, Gustafsson JA (2001): Mechanisms of estrogen action. Physiol Rev 81(4): 1535-1565

Ohtake F, Baba A, Takada I, Okada M, Iwasaki K, Miki H, Takahashi S, Kouzmenko A, Nohara K, Chiba T et al. (2007): Dioxin receptor is a ligand-dependent E3 ubiquitin ligase. Nature 446 (7135): 562-566

Petersen DN, Tkalcevic GT, Koza-Taylor PH, Turi TG, Brown TA (1998): Identification of estrogen receptor beta2, a functional variant of estrogen receptor beta expressed in normal rat tissues. Endocrinology 139 (3): 1082-1092.

Petrulis JR, Bunce NJ (1999): Competitive inhibition by inducer as a confounding factor in the use of the ethoxyresorufin-O-deethylase (EROD) assay to estimate exposure to dioxin-like compounds. Toxicol Lett 105 (3): 251-260

Petrulis JR, Chen G, Benn S, LaMarre J, Bunce NJ (2001): Application of the ethoxyresorufin-O-deethylase (EROD) assay to mixtures of halogenated aromatic compounds. Environ Toxicol 16(2): 177-184

Pitot HC, Peraino C, Morse PA, Jr., Potter VR (1964): Hepatomas In Tissue Culture Compared With Adapting Liver In Vivo. Natl Cancer Inst Monogr $\underline{13}$ 229-245

Poland A, Knutson JC (1982): 2,3,7,8-tetrachlorodibenzo-p-dioxin and related halogenated aromatic hydrocarbons: examination of the mechanism of toxicity. Annu Rev Pharmacol Toxicol 22 517-554

Poland A, Glover E, Kende AS (1976): Stereospecific, high affinity binding of 2,3,7,8tetrachlorodibenzo-p-dioxin by hepatic cytosol. Evidence that the binding species is receptor for induction of aryl hydrocarbon hydroxylase. J Biol Chem 251 (16): 4936-4946

Pongratz I, Mason GG, Poellinger L (1992): Dual roles of the 90-kDa heat shock protein hsp90 in modulating functional activities of the dioxin receptor. Evidence that the dioxin receptor functionally belongs to a subclass of nuclear receptors which require hsp90 both for ligand binding activity and repression of intrinsic DNA binding activity. J Biol Chem 267 (19): 13728-13734

Pongratz I, Antonsson C, Whitelaw ML, Poellinger L (1998): Role of the PAS domain in regulation of dimerization and DNA binding specificity of the dioxin receptor. Mol Cell Biol 18 (7): 4079-4088

Pratt WB, Toft DO (1997): Steroid receptor interactions with heat shock protein and immunophilin chaperones. Endocr Rev 18 (3): 306-360

Razandi M, Pedram A, Levin ER (2000): Plasma membrane estrogen receptors signal to antiapoptosis in breast cancer. Mol Endocrinol 14 (9): 1434-1447

Reen RK, Cadwallader A, Perdew GH (2002): The subdomains of the transactivation domain of the aryl hydrocarbon receptor (AhR) inhibit AhR and estrogen receptor transcriptional activity. Arch Biochem Biophys 408 (1): 93-102 
Ricci MS, Toscano DG, Mattingly CJ, Toscano WA, Jr. (1999): Estrogen receptor reduces CYP1A1 induction in cultured human endometrial cells. J Biol Chem 274 (6): 3430-3438

Rier S, Foster WG (2003): Environmental dioxins and endometriosis. Semin Reprod Med 21 (2): $145-154$

Ruegg J, Swedenborg E, Wahlstrom D, Escande A, Balaguer P, Pettersson K, Pongratz I (2008): The transcription factor aryl hydrocarbon receptor nuclear translocator functions as an estrogen receptor beta-selective coactivator, and its recruitment to alternative pathways mediates antiestrogenic effects of dioxin. Mol Endocrinol $\underline{22}$ (2): 304-316

Safe S (1990): Polychlorinated biphenyls (PCBs), dibenzo-p-dioxins (PCDDs), dibenzofurans (PCDFs), and related compounds: environmental and mechanistic considerations which support the development of toxic equivalency factors (TEFs). Crit Rev Toxicol 21 (1): 51-88

Safe S (1998): Hazard and risk assessment of chemical mixtures using the toxic equivalency factor approach. Environ Health Perspect 106 Suppl 4 1051-1058

Safe S (2004): Endocrine disruptors and human health: is there a problem. Toxicology 205 (12): $3-10$

Safe S,Wormke M (2003): Inhibitory aryl hydrocarbon receptor-estrogen receptor alpha cross-talk and mechanisms of action. Chem Res Toxicol 16 (7): 807-816

Sambrook J, Fritsch EF, Maniatis T: Molecular Cloning: a laboratory manual. Cold Spring Harbour Laboratory press, New York 1989

Sarkar S, Jana NR, Yonemoto J, Tohyama C, Sone H (2000): Estrogen enhances induction of cytochrome P-4501A1 by 2,3,7, 8-tetrachlorodibenzo-p-dioxin in liver of female Long-Evans rats. Int J Oncol 16 (1): 141-147

Saville B, Wormke M, Wang F, Nguyen T, Enmark E, Kuiper G, Gustafsson JA, Safe S (2000): Ligand-, cell-, and estrogen receptor subtype (alpha/beta)-dependent activation at GC-rich (Sp1) promoter elements. J Biol Chem 275 (8): 5379-5387

Schecter A, Cramer P, Boggess K, Stanley J, Papke O, Olson J, Silver A, Schmitz M (2001): Intake of dioxins and related compounds from food in the U.S. population. $J$ Toxicol Environ Health A 63 (1): 1-18

Schecter A, Pavuk M, Constable JD, Dai le C, Papke O (2002): A follow-up: high level of dioxin contamination in Vietnamese from agent orange, three decades after the end of spraying. J Occup Environ Med 44 (3): 218-220

Schecter A, Birnbaum L, Ryan JJ, Constable JD (2006): Dioxins: an overview. Environ Res 101 (3): 419-428 
Schlumpf M, Cotton B, Conscience M, Haller V, Steinmann B, Lichtensteiger W (2001): In vitro and in vivo estrogenicity of UV screens. Environ Health Perspect 109 (3): 239-244

Schlumpf M, Schmid P, Durrer S, Conscience M, Maerkel K, Henseler M, Gruetter M, Herzog I, Reolon S, Ceccatelli R et al. (2004): Endocrine activity and developmental toxicity of cosmetic UV filters--an update. Toxicology 205 (1-2): 113-122

Schreurs R, Lanser P, Seinen W, van der Burg B (2002): Estrogenic activity of UV filters determined by an in vitro reporter gene assay and an in vivo transgenic zebrafish assay. Arch Toxicol 76 (5-6): 257-261

Seidlová-Wuttke D, Christoffel J, Rimoldi G, Jarry H, Wuttke W (2006a): Comparison of effects of estradiol with those of octylmethoxycinnamate and 4methylbenzylidene camphor on fat tissue, lipids and pituitary hormones. Toxicol Appl Pharmacol 214 (1): 1-7

Seidlová-Wuttke D, Jarry H, Christoffel J, Rimoldi G, Wuttke W (2006b): Comparison of effects of estradiol (E2) with those of octylmethoxycinnamate (OMC) and 4methylbenzylidene camphor (4MBC)--2 filters of UV light - on several uterine, vaginal and bone parameters. Toxicol Appl Pharmacol 210 (3): 246-254

Selgrade MK (2007): Immunotoxicity: the risk is real. Toxicol Sci 100 (2): 328-332

Sharpe RM, Skakkebaek NE (1993): Are oestrogens involved in falling sperm counts and disorders of the male reproductive tract? Lancet 341 (8857): 1392-1395

Shertzer HG, Puga A, Chang C, Smith P, Nebert DW, Setchell KD, Dalton TP (1999): Inhibition of CYP1A1 enzyme activity in mouse hepatoma cell culture by soybean isoflavones. Chem Biol Interact 123 (1): 31-49

Shimizu Y, Nakatsuru Y, Ichinose M, Takahashi Y, Kume H, Mimura J, Fujii-Kuriyama Y, Ishikawa T (2000): Benzo[a]pyrene carcinogenicity is lost in mice lacking the aryl hydrocarbon receptor. Proc Natl Acad Sci U S A 97 (2): 779-782

Son DS, Roby KF, Rozman KK, Terranova PF (2002): Estradiol enhances and estriol inhibits the expression of CYP1A1 induced by 2,3,7,8-tetrachlorodibenzo-p-dioxin in a mouse ovarian cancer cell line. Toxicology 176 (3): 229-243

Spink DC, Lincoln DW, 2nd, Dickerman HW, Gierthy JF (1990): 2,3,7,8-

Tetrachlorodibenzo-p-dioxin causes an extensive alteration of 17 beta-estradiol metabolism in MCF-7 breast tumor cells. Proc Natl Acad Sci U S A 87 (17): 69176921

Spink DC, Eugster HP, Lincoln DW, 2nd, Schuetz JD, Schuetz EG, Johnson JA, Kaminsky LS, Gierthy JF (1992): 17 beta-estradiol hydroxylation catalyzed by human cytochrome P450 1A1: a comparison of the activities induced by 2,3,7,8tetrachlorodibenzo-p-dioxin in MCF-7 cells with those from heterologous expression of the cDNA. Arch Biochem Biophys 293 (2): 342-348 
Swedenborg E, Ruegg J, Makela S, Pongratz I (2009): Endocrine disruptive chemicals: mechanisms of action and involvement in metabolic disorders. $J$ Mol Endocrinol 43 (1): $1-10$

Swope DL, Korach KS (2003). Estrogen Receptor Biology and Lessons from Knockout Mice. Encyclopedia of Hormones HL Henry and AW Norman, Elsevier Science, USA 2003

Takeuchi T, Tsutsumi O, Ikezuki Y, Takai Y, Taketani Y (2004): Positive relationship between androgen and the endocrine disruptor, bisphenol A, in normal women and women with ovarian dysfunction. Endocr J 51 (2): 165-169

Thierfelder W, Mehnert WH, Laußmann D, Arndt D, Reineke HH (1995): Der Einfluss umweltrelevanter östrogener oder östrogenartiger Substanzen auf das Reproduktionssystem. Bundesgesundheitsblatt 38 337-341

Tijet N, Boutros PC, Moffat ID, Okey AB, Tuomisto J, Pohjanvirta R (2006): Aryl hydrocarbon receptor regulates distinct dioxin-dependent and dioxin-independent gene batteries. Mol Pharmacol 69 (1): 140-153

Tinwell H, Lefevre PA, Moffat GJ, Burns A, Odum J, Spurway TD, Orphanides G, Ashby J (2002): Confirmation of uterotrophic activity of 3-(4-methylbenzylidine)camphor in the immature rat. Environ Health Perspect 110 (5): 533-536

Toft D, Gorski J (1966): A receptor molecule for estrogens: isolation from the rat uterus and preliminary characterization. Proc Natl Acad Sci U S A 55 (6): 1574-1581

Toppari J, Larsen JC, et al. (1996): Male reproductive health and environmental xenoestrogens. Environ Health Perspect 104 Suppl 4 741-803

Van den Berg M, Birnbaum L, et al. (1998): Toxic equivalency factors (TEFs) for PCBs, PCDDs, PCDFs for humans and wildlife. Environ Health Perspect 106 (12): 775792

Van Maele-Fabry G, Libotte V, Willems J, Lison D (2006): Review and meta-analysis of risk estimates for prostate cancer in pesticide manufacturing workers. Cancer Causes Control 17 (4): 353-373

Verhallen EY, Berg vdM, Bosveld ATC (1997): Interactive effects on the EROD-inducing potency of polyhalogenated aromatic hydrocarbons in the chicken embryo hepatocite assay Environmental Toxicology and Chemistry 16 (2): 277-282

Völkel W, Colnot T, Schauer UM, Broschard TH, Dekant W (2006): Toxicokinetics and biotransformation of 3-(4-methylbenzylidene)camphor in rats after oral administration. Toxicol Appl Pharmacol 216 (2): 331-338

Welshons WV, Lieberman ME, Gorski J (1984): Nuclear localization of unoccupied oestrogen receptors. Nature 307 (5953): 747-749

White R, Parker MG (1998): Molecular mechanisms of steroid hormone action. Endocrinerelated Cancer $\underline{5} 1-14$ 
Whyte JJ, Jung RE, Schmitt CJ, Tillitt DE (2000): Ethoxyresorufin-O-deethylase (EROD) activity in fish as a biomarker of chemical exposure. Crit Rev Toxicol 30 (4): 347570

Whyte JJ, Schmitt CJ, Tillitt DE (2004): The H4IIE cell bioassay as an indicator of dioxinlike chemicals in wildlife and the environment. Crit Rev Toxicol 34 (1): 1-83

Wormke M, Castro-Rivera E, Chen I, Safe S (2000): Estrogen and aryl hydrocarbon receptor expression and crosstalk in human Ishikawa endometrial cancer cells. J Steroid Biochem Mol Biol 72 (5): 197-207

Wormke M, Stoner M, Saville B, Walker K, Abdelrahim M, Burghardt R, Safe S (2003): The aryl hydrocarbon receptor mediates degradation of estrogen receptor alpha through activation of proteasomes. Mol Cell Biol 23 (6): 1843-1855

Yabusaki Y, Shimizu M, Murakami H, Nakamura K, Oeda K, Ohkawa H (1984): Nucleotide sequence of a full-length cDNA coding for 3-methylcholanthrene-induced rat liver cytochrome P-450MC. Nucleic Acids Res 12 (6): 2929-2938

Yalow RS, Berson SA (1959): Assay of plasma insulin in human subjects by immunological methods. Nature 184 (Suppl 21) 1648-1649

Yang JZ, Agarwal SK, Foster WG (2000): Subchronic exposure to 2,3,7,8tetrachlorodibenzo-p-dioxin modulates the pathophysiology of endometriosis in the cynomolgus monkey. Toxicol Sci 56 (2): 374-381 


\section{$7 \quad$ Anhang}

\subsection{Primersequenzen}

Tabelle 7.1

Primer- und Sondensequenzen für die verwendeten PCR Systeme (mit der dazugehörigen AccessionNummer der NCBI-Datenbank beziehungsweise Referenz)

\begin{tabular}{|c|c|c|c|c|c|c|}
\hline 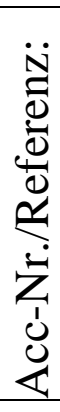 & & 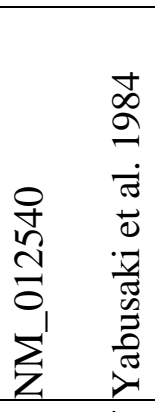 & 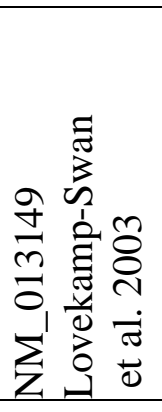 & 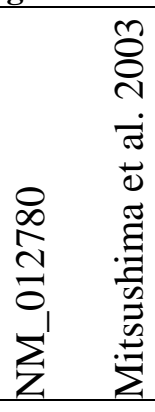 & & 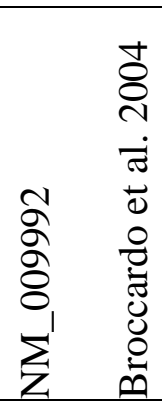 \\
\hline 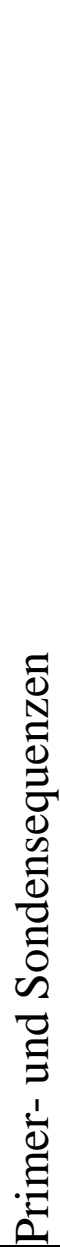 & & 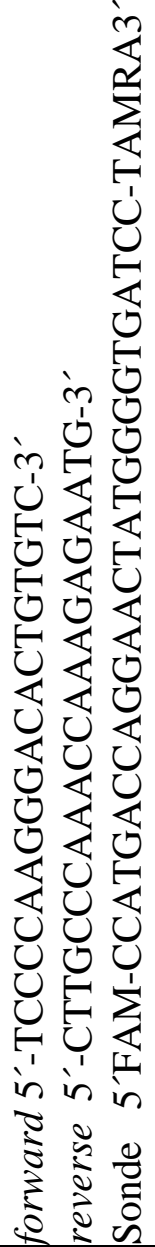 & $\begin{array}{l}1 \\
\end{array}$ & 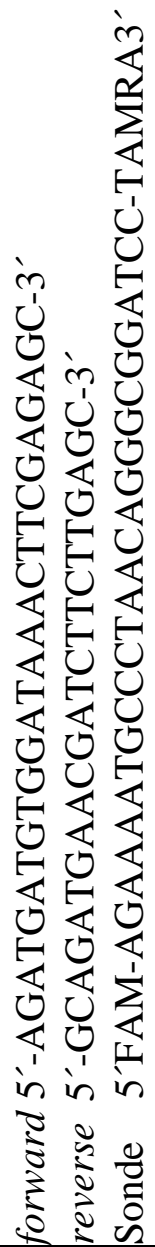 & & 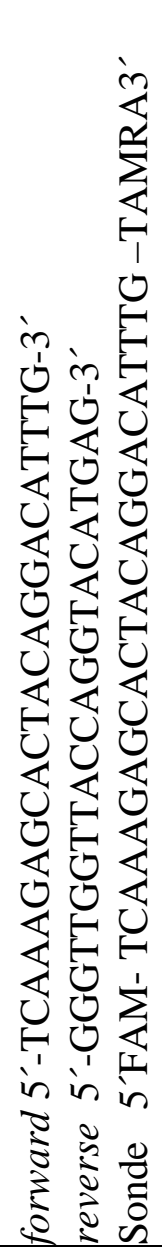 \\
\hline$\overline{0}$ & 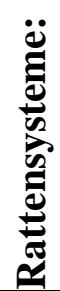 & ú & 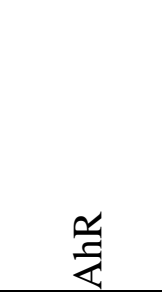 & 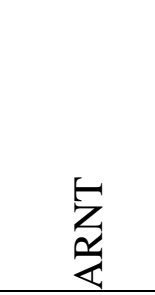 & 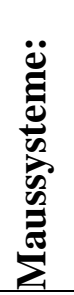 & 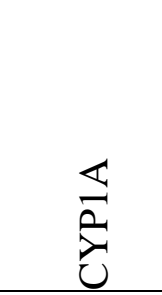 \\
\hline
\end{tabular}




\section{Danksagung}

An dieser Stelle möchte ich mich vor allem ganz herzlich bei meinem Doktorvater, Prof. Dr. rer. nat. Hubertus Jarry, für die hervorragende Betreuung dieser Dissertation bedanken. Seine stete Ansprechbarkeit und auch seine Bereitschaft zur Klärung aller labortechnischen Probleme haben zum Gelingen dieser Arbeit immens beigetragen. Besonders seine Begeisterung für die Forschung sowie seine menschliche und fachliche Kompetenz waren für mich immer sehr motivierend.

Zudem gilt mein Dank allen weiteren Mitarbeitern und Mitarbeiterinnen sowie Doktoranden der ehemaligen Abteilung für Klinische und Experimentelle Endokrinologie der Universitätsklinik Göttingen unter der Leitung von Herrn Prof. Dr. med. W. Wuttke, die mich mit den verschiedensten Labormethoden vertraut gemacht und alle meine Fragen geduldig beantwortet haben. 